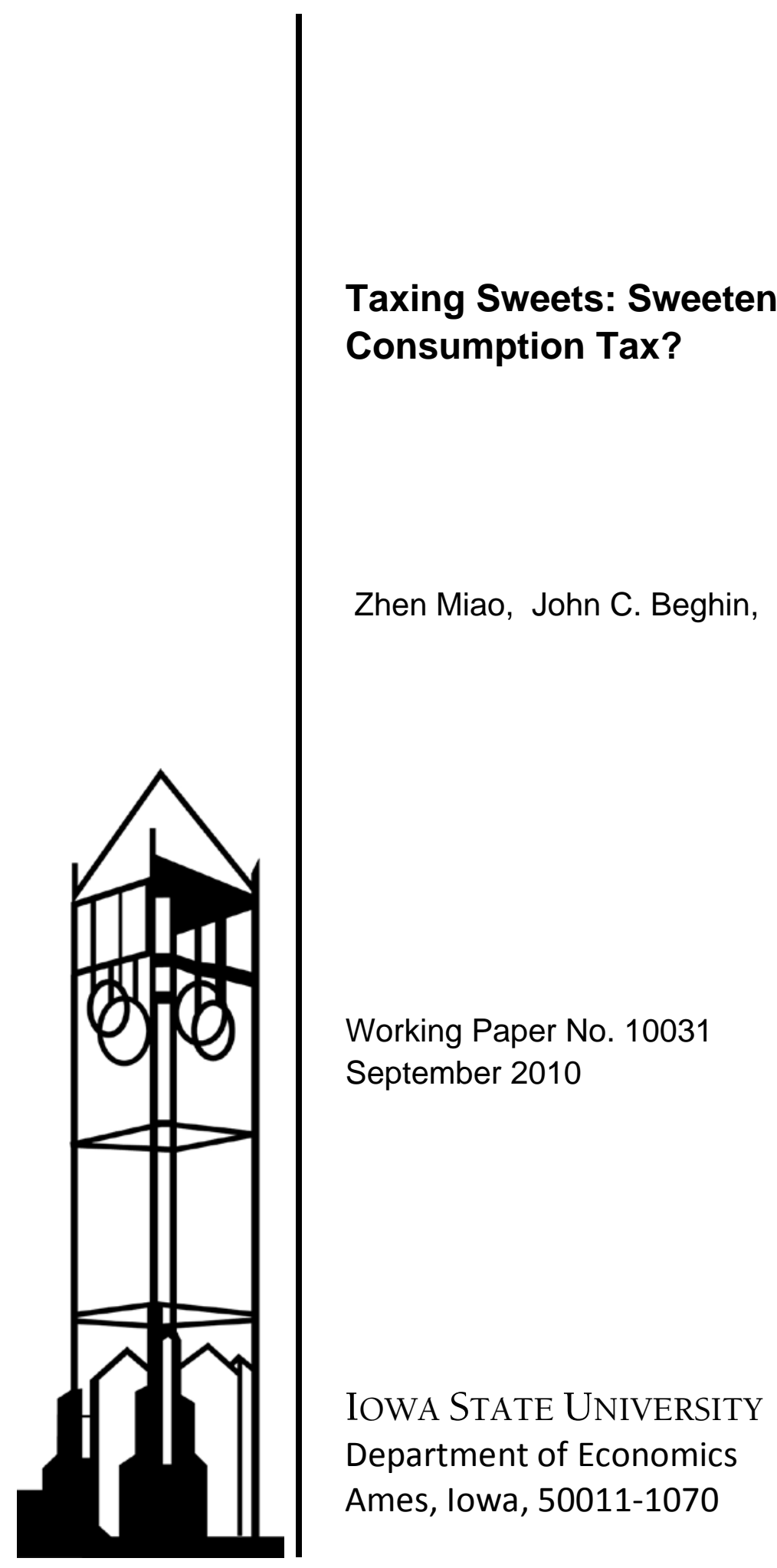

lowa State University does not discriminate on the basis of race, color, age, religion, national origin, sexual orientation, gender identity, sex, marital status, disability, or status as a U.S. veteran. Inquiries can be directed to the Director of Equal Opportunity and Diversity, 3680 Beardshear Hall, (515) 294-7612. 


\title{
Taxing Sweets: Sweetener Input Tax or Final Consumption Tax?
}

\author{
Zhen Miao, John C. Beghin, and Helen H. Jensen \\ Working Paper 10-WP 510 \\ July 2010 \\ Center for Agricultural and Rural Development \\ lowa State University \\ Ames, lowa 50011-1070 \\ www.card.iastate.edu
}

\begin{abstract}
Zhen Miao is a graduate research assistant in the Department of Economics and Center for Agricultural and Rural Development at lowa State University. John Beghin is a Marlin Cole Professor of International Agricultural Economics in the Department of Economics at lowa State University. Helen Jensen is a professor of economics in the Department of Economics and Center for Agricultural and Rural Development at lowa State University.
\end{abstract}

The authors acknowledge partial financial support from USDA under the National Research Initiative Program (2006-55215-16720). Dr. Beghin also acknowledges support from the Marlin Cole Professorship.

This paper is available online on the CARD Web site: www.card.iastate.edu. All rights reserved. Permission is granted to excerpt or quote this information with appropriate attribution to the authors. Readers may make verbatim copies for non-commercial purposes provided copyright notice appears on all such copies.

Questions or comments about the contents of this paper should be directed to Helen Jensen, 578 Heady Hall, lowa State University, Ames, IA 50011-1070; Ph: (515) 294-6253; E-mail: hhjensen@iastate.edu.

The U.S. Department of Agriculture (USDA) prohibits discrimination in all its programs and activities on the basis of race, color, national origin, gender, religion, age, disability, political beliefs, sexual orientation, and marital or family status. (Not all prohibited bases apply to all programs.) Persons with disabilities who require alternative means for communication of program information (Braille, large print, audiotape, etc.) should contact USDA's TARGET Center at (202) 720-2600 (voice and TDD). To file a complaint of discrimination, write USDA, Director, Office of Civil Rights, Room 326-W, Whitten Building, 14th and Independence Avenue, SW, Washington, DC 20250-9410 or call (202) 720-5964 (voice and TDD). USDA is an equal opportunity provider and employer. 


\begin{abstract}
In order to reduce obesity and associated costs, policymakers are considering various policies, including taxes, to change consumers' high-calorie consumption habits. We investigate two tax policies aimed at reducing added sweetener consumption. Both a consumption tax on sweet goods and a sweetener input tax can reach the same policy target of reducing added sweetener consumption. Both tax instruments are regressive, but the associated surplus losses are limited. The tax on sweetener inputs targets sweeteners directly and causes about five times less surplus loss than the final consumption tax. Previous analyses have overlooked this important point.
\end{abstract}

Keywords: added sweeteners, consumption tax, demand, health policy, soda tax, sugar. 


\section{Taxing Sweets: Sweetener Input Tax or Final Consumption Tax?}

\section{Introduction}

Obesity has become a major public health concern in the United States as well as throughout the world. In 2007-08, 32.2\% of men and 35.5\% of women (20 years of age and older) were obese (Flegal et al., 2010). Although the rate for women has not increased over the last decade, and the rate for men has been constant during the last several years, obesity rates indicate a major and continuing public health problem. Obesity is most often a result of an imbalance between excess calorie intake and reduced physical activity. In the last three decades, on average, American consumers have consumed more calories, especially in the form of refined grains, total fats, and added sugars. From 1970 to 2003 the per capita average daily calorie intake grew by 523 calories. The main contributors to the increase were fats and oils (216 calories), refined grains (188 calories), and all sweeteners (76 calories) (Farah and Buzby, 2005).

In order to reduce the costs of obesity, policymakers have debated and tried various policies and programs to change the consumption of high-calorie foods and reduce the prevalence of obesity. The current (2005) dietary guidelines issued by the Department of Health and Human Services (HHS) and U.S. Department of Agriculture (USDA) recommend limiting the intake of trans-fats and added sugar (HHS and USDA 2005). Among policies considered, one approach is to use price penalties and incentives such as a soda tax or a subsidy on healthy food to change consumption. Altered incentives might encourage consumers to follow a healthy diet even though they might discount the long-run health costs of unhealthy food (O'Donoghue and Rabin, 1999). Because fats and oils, refined grains, and sugar and sweeteners are the major contributors to the higher-calorie consumption, proposals to tax these products are popular as a means to reduce their intake (Kuchler, Tegene, and Harris, 2004 and 2005; Gustavsen, 2005; Schroeter, Lusk, and Tyner, 2008; Cash, Sunding, and Zilberman, 2005; Smed, Jensen, and Denver, 2007; Richards, Patterson, and Tegene, 2007; and Chouinard et al., 2007).

We focus on tax policies targeted to reduce added sweetener consumption and investigate the effect of alternative policies to reduce sweetener intake. Taxing added sweeteners is often discussed but less often thoroughly analyzed than policies to reduce consumption of high-fat foods. Taxing sweets can be undertaken at two levels: the consumption level or the production level. Applying a tax to a specific type of sweetened food directly changes the food price and thus likely reduces the consumer demand for the sweetened food.

Alternatively, policymakers can induce manufacturers to reduce the use of sweetenerintensive ingredients in food processing by imposing a tax on sweetener ingredients. Manufacturers choose among available technologies and ingredients, and, to some extent, the manufacturers can substitute among different sweeteners and away from certain sweeteners in the production process. A tax on sweetener inputs increases their marginal cost and hence the price of final food products offered. Faced with a higher price, consumers reduce their consumption of final products. The extent to which the extra costs are transmitted along the food chain affects the final market price and ultimately determines the effectiveness of the tax imposed on manufacturers as a means to reduce consumption of the sweetener-intensive final food products.

Both a final consumption tax and a tax on manufacturer ingredients can reach the same policy target of reducing the consumption of added sweeteners and associated added calories. 
The objective of our research is to explore the effect of taxes on inputs and on final goods designed to reduce consumption of sweeteners. We evaluate the level of each of these taxes required to achieve a given reduction in sweeteners. An empirical model, along with data from industry and recent research studies, is used to evaluate the magnitude of the effects the policy instruments have on consumption and on welfare, as well as the distributional effects across income groups. We compare the allocative efficiency of both instruments (the tax on final consumption and the tax on manufacturing ingredients) and conclude that although they are both regressive and of small magnitude, a tax on sweetener inputs causes a smaller loss in welfare (about five times less) than does a tax on final products, such as a soda tax.

Almost all previous studies that have focused on a consumption tax have found such a tax to be regressive. In our investigation, we fix a $10 \%$ reduction in sugar equivalent quantity of added sweetener consumption (around 13.13 grams per capita of daily sugar equivalent, which contain 52.54 calories) as the policy target and minimize the associated welfare loss. The following section summarizes several related studies directed at a tax policy on high-calorie foods. Next, the model section presents the model of the food sector we use to evaluate the response of industry and consumers to prices of sweeteners and sweetened goods. The data section introduces the 2002 Economic Census manufacturing report data, the USDA Food Availability Data System, the USDA Commodity and Food Elasticities data, and the data in the Consumer Expenditure Survey of the Bureau of Labor Statistics that we use in this paper. The calculation of the LinQuad incomplete food demand system and the welfare analysis are discussed in the results section.

\section{Literature Review}

The food industry uses sweeteners as ingredients in the manufacturing process. Progress in agricultural technology has lowered the cost of both corn and high fructose corn syrup (HFCS) more than the cost of sugar by increasing productivity in corn production over time relatively more than that in sugar production (Beghin and Jensen, 2008). In addition, the price of sugar in the U.S. has long been above the average world level because trade restrictions have kept the cost of using sugar well above its opportunity cost. Conversely, corn subsidies have lowered the price of corn sweeteners. As a result, corn-based sweeteners are relatively cheaper compared to sugar and have experienced a sharp rise in use by manufacturers. HFCS is widely used in the beverage, breakfast cereal and bakery, and dairy industries (Beghin and Jensen, 2008).

The effectiveness of taxing high-calorie foods has been analyzed previously. The general findings are that this type of market intervention can change consumers' dietary choices, but the effects of tax policy are limited, and the tax on select foods is often regressive. Santarossa and Mainland (2003) found that consumers tend to replace harmful foods with healthier ones when there is a price increase for unhealthy high-energy foods. In an empirical study based on household consumption data from 1989 to 1999, Gustavsen (2005) showed that a tax on soft drinks may efficiently reduce demand and the decrease is more significant in heavy drinkers than in light drinkers because heavy drinkers are more price and expenditure elastic. Richards, Patterson, and Tegene (2007) found that the craving for different foods is rational and argued that a tax on high-energy foods may be more efficient in reducing their consumption than information-based policies.

Although it is expected that price interventions will induce consumers to choose diets

with fewer calories and to move to a healthier eating style, the effects of these policies depend on 
which foods are affected; to what extent the final price changes; the availability of close, healthy substitutes on the market; and, finally, how different consumers respond to the adjusted market (Schmidhuber, 2004; Cash, Sunding, and Zilberman, 2005). In practice, the effectiveness of tax policy could be complicated by other factors or could be limited. For example, Kuchler, Tegene, and Harris (2004; 2005) studied the possible consumption impact and health outcome associated with a simulated tax on snack foods. Under the assumption that no substitutable foods were available, they found that although a relatively small tax rate of $1 \%$ could generate some revenue for public health education, it did not reduce purchases by much and therefore had relatively little influence on diet quality and health outcomes.

Chouinard et al. (2007) analyzed supermarket scanner data to characterize the effects of a fat tax on dairy products. They showed that a $10 \%$ tax on fat content would reduce fat consumption by less than 1\%; a 50\% tax would cause a 3\% intake reduction. They concluded that the limited effects of the taxes on demand are because dairy product demand is not price elastic. Thus, a fat tax on dairy is best used to enhance revenue. This investigation only included dairy products that contain fats and did not take non-fat substitute foods into account.

A few studies that considered the effect of substitution related to taxing specific foods found that the ultimate effect on total calorie consumption (and hence on body weight) would depend on substitutability and complementarity among products with different calorie intensities. Boizot-Szantaï and Etilé (2005) used French food-at-home expenditure data and analyzed the price effects of various foods on Body Mass Index (BMI). They show that the resulting price effect on weight was affected by the possibility of substitution between similar or diverse foods, and they suggest that in the short term the effectiveness of a nutritional tax may be limited. Taxing one of the food components may cause substitutions that reduce the effectiveness of the policies to reduce overall calories intake.

A study based on weekly shopping records of 23 food categories in Denmark considered several food components-sweeteners, fiber, and fat-at the same time. Smed, Jensen, and Denver (2007) utilized the Almost Ideal Demand (AID) model to show that if a sugar tax is applied, sugar demand is reduced but demand for saturated fat increases. If a tax on saturated fat as well as a subsidy on fiber is imposed, the demand for saturated fat will go down but the sugar demand will go up. The unwanted increase in sugar demand disappears when combining the saturated fat tax and fiber subsidy with a tax on sugar.

Another issue is that the expenditure shares of food and consumption behaviors may differ among different socio-economic groups. In order to most effectively apply policies to reduce consumption of high-calorie, high-fat or sweetener-intensive foods, policy analysts need to disaggregate food-specific demand estimates according to socio-economic status, and assess the possible impact of policy changes on food consumption and welfare outcomes at a more disaggregated level in addition to the total effects. The estimated disaggregated effects can provide policymakers with information on the direction and extent of possible tax changes and help them identify those who stand to benefit or lose from the policy changes.

Differences in consumption across income groups have implications for the incidence and distributional effects of the taxes. Consumers at different income levels spend different portions of their income on foods. The share spent on foods is relatively large for consumers with lower income. Thus, tax policy that increases food prices will be regressive (Cash, Sunding, and Zilberman, 2005). From the investigation of the 2000 U.K. National Food Survey, Leicester and Windmeijer (2004) showed that the proportion of income spent on a "fat tax" for the poorest households is seven times that of richest households. Chouinard et al. (2007) showed that 
although there was little price elasticity variation for dairy products among different demographic groups, differences across income groups do occur as a result of different income elasticities and budget shares. A fat tax would be regressive, with the tax being borne almost exclusively by low-income consumers. The loss of welfare for households with $\$ 20,000$ in annual income is twice that of households with $\$ 100,000$ in income in terms of dollar values while it is ten times as much in terms of the fraction of equivalent variation in annual income.

In summary, most existing studies focused on the consumption tax on snack foods or fat foods and found that it is regressive, although the magnitude of the welfare loss to consumers is small. It is important to note, however, that the findings on the regressive nature of these taxes may be overstated because low-income groups benefit the most-in a relative sense-from the reduced consumption of caloric food through improvements in their health status. The use of a food tax is based on the assumption that the current food price involves only the direct cost of consumption but does not capture the potential future health-care cost that consuming highcalorie food might bring. Obesity imposes social costs related to health care. In order to fully account for the social costs of increased future health care, a food price should reflect and include both the direct food production costs as well as future potential medical care costs of treating obesity-related diseases. If the free market fails to incorporate all the costs, a food tax could be introduced to set the price faced by consumers to a level that also reflects future costs.

\section{Model}

We rely on a multi-market, partial equilibrium displacement model encompassing four sweetener markets, multiple food processing sectors intensive in sweetener inputs, and several final consumer groups differentiated by income levels. The approach is well established and has been applied in various policy analysis contexts (Mullen, Wohlgenant, and Farris, 1988; Atwood and Helmers, 1998; Beghin, Bureau, and Drogué, 2004; and Sumner and Wohlgenant, 1985; among others). These added sweeteners are inputs used in food processing industries. We assume that there is an infinite supply in the added sweeteners markets so that the added sweeteners' prices (before taxes) remain parametric and can be taken as given throughout our analysis. The input taxes imposed on one or more sweeteners will influence their relative prices.

For the final foods markets, we first model the supply decisions of the food processors. We show how they transfer the sweet input tax onto the price of final products and by doing so we abstract from having an explicit retailing sector between food processors and consumers. Then we model the demand for the sweetener-intensive foods from the consumer's perspective. Finally, we combine these two sides to evaluate consumer welfare changes due to a tax on final products and on the manufacturing component sweeteners. The welfare change in our analysis is only measured by the equivalent variation corresponding to the price changes. By doing this, we abstract from the fact that consumers' health condition is an important component of their utility function. Consumers get immediate satisfaction from food consumption but the associated health costs will emerge in the future.

\section{Producer's side}

We first consider a tax imposed on sweetener inputs at the production level in food processing. Under a tax imposed at the production level, the degree of competition in the market and the ability to substitute among inputs determine the extent to which the cost is passed on to the final consumers by the manufacturers of sweetener-intensive foods. As in many analyses, we assume 
that changes in production cost would be fully transmitted at the consumer level as under perfect competition. Under this assumption, the calculation of consumer expenditure and welfare change provides an upper bound of the potential burden of the tax on consumers.

For each food manufacturing industry, the total cost of production and the cost share of each input are determined by input prices. In food manufacturing industry $i$, the input price $w_{i k}$ of input $k$ is a function of pre-tax input price $\tilde{w}_{i k}$ and input tax $t_{i k}$, so that $w_{i k}=\tilde{w}_{i k}\left(1+t_{i k}\right)$. Under the assumption of constant returns to scale, marginal cost equals average cost, and total costs increase in direct proportion to output. The change of marginal cost is proportional to the change in input prices. That is,

$$
d\left(\ln M C_{i}\right)=\sum_{k} s_{i k} d \ln w_{i k}=\sum_{k} s_{i k} d \ln \left(1+t_{i k}\right),
$$

where $M C_{i}$ is the marginal cost of production for food manufacturing industry $i$, and $s_{i k}$ is the cost share of input $k$ in total cost and whose input price is $w_{i k}$. We assume that final food producer prices $P P_{i}$ are set above marginal cost with constant markup coefficient $\theta_{i}$ such that

$$
\theta_{i}=\frac{P P_{i}-M C_{i}}{P P_{i}}
$$

The producer price setting for the final product in food manufacturing industry $i, P P_{i}$, is

$$
P P_{i}=\frac{M C_{i}}{1-\theta_{i}}
$$

The model from the producer's side captures the food processors' response to the change of the input prices. But by assuming the markup coefficient $\theta_{i}$ to be constant, we are abstracting away from the retail sector, which acts between the food processors and consumers. When the input price changes, the retail sector may also adjust its pricing strategy to maximize its profit so that the markup is not always constant. An increase in the markup will cause the final price of the food to increase in addition to the impact of the input price changes, and a decrease in the markup will cause the final price of the food to decrease in addition to the impact of the input price changes. For simplicity, we assume the markup does not change and only account for the food processors' response to the change of the input prices. A variable markup could be accommodated without difficulty but would induce some clutter.

At equilibrium, the proportional changes in food price reflect the relative changes in input prices weighted by their respective cost share in the cost of the food. A $100 \%$ increase in sweetener price weighted by a cost share of sweetener $s_{i k}$ in retail cost will cause an $s_{i k}$ increase in final food prices. Under the assumption of constant markup, the tax on sweetener prices is transmitted to consumers of sweetener-intensive foods through higher input prices and thus output prices. If a tax rate $t_{i k}$ is applied to sweetener $k$, the input price of sweetener $k$ is effectively $\tilde{w}_{i k}\left(1+t_{i k}\right)$, then any change in the input tax rate changes the input price and output price by

$$
d \ln w_{i k}=d \ln \tilde{w}_{i k}\left(1+t_{i k}\right)=d \ln \left(1+t_{i k}\right),
$$

and

$$
d \ln P P_{i}=d \ln \frac{M C_{i}}{1-\theta_{i}}=d \ln M C_{i}=\sum_{k} s_{i k} d \ln w_{i k}=\sum_{k} s_{i k} d \ln \left(1+t_{i k}\right)
$$


A higher price induced by the tax on one sweetener would decrease the demand for that sweetener input and could boost the use of another sweetener or other inputs. Holding other things constant, higher prices for some sweeteners would cause substitution among sweeteners and raise the production cost of sweetener-intensive food. The change of the usage of sweetener $h$ caused by a tax on sweeteners $k$ can be expressed as

$$
d \ln x_{i h}=d \ln y_{i}+\sum_{k} s_{i k} \sigma_{i h k} d \ln w_{i k}=d \ln y_{i}+\sum_{k} \delta_{i h k} d \ln \left(1+t_{i k}\right) .
$$

where $x_{i}$ is the quantity of the sweetener input in industry $i, y_{i}$ is the quantity of output for industry $i, \sigma_{i n k}$ is the elasticity of substitution between inputs $h$ and $k$ in food manufacturing industry $i$, and $\delta_{i h k}$ is the cross-price elasticity between inputs $h$ and $k$ in food manufacturing industry $i$ satisfying the condition that

$$
\delta_{i h k}=s_{i k} \sigma_{i h k} \text { and } \delta_{i k k}=s_{i k} \sigma_{i k k} \text {. }
$$

\section{Consumer's side}

On the consumer's side, we are mostly interested in the sweetener-intensive foods because sweetener consumption and consumer-level effects are our main research focus. The LinQuad incomplete demand systems approach developed by LaFrance (1998) is adopted to derive consumer demand equations and welfare evaluations. LinQuad system is linear in income and quadratic in price. This incomplete demand system fits well here because only a subset of all the foods is relevant to our analysis. It has a more common form than do complete systems and is more flexible in its ability to reflect consumer preferences by incorporating the quadratic price term. It is also easy to calibrate while imposing proper curvature (Beghin, Bureau, and Drogué, 2004).

Let $D=\left[D_{1}, \ldots, D_{m}\right]$ ' be the vector of demands for the target foods, $P=\left[P_{1}, \ldots P_{m}\right]$ ' be the corresponding price vector, $P_{O}=\left[P_{O 1}, \ldots P_{O z}\right]$ ' be the price vector for all the remaining foods $O=\left[O_{1}, \ldots, O_{z}\right]^{\prime}$, and $I$ be the income level. These prices can include an ad valorem consumption tax. In this case, the producer and final consumer prices are linked through the identity $P_{i}=P P_{i}\left(1+\tau_{i}\right)$, where $\tau_{i}$ is the consumer tax imposed on final good $i$. The consumer tax $\tau$ is the second instrument we consider to abate sweetener consumption.

The consumer's utility maximization problem under the budget constraint is

$$
\underset{D, O}{\operatorname{Max}} U(D, O) \text { s.t. } P^{\prime} D+P_{O}^{\prime} O \leq I
$$

where $U$ represents the utility function. The Marshallian demands $D=D\left(P^{\prime}, P_{O}^{\prime}, I\right)$ satisfying the above maximization problem have the following properties: (a) demands are positive, $D=D\left(P^{\prime}, P_{O}{ }^{\prime}, I\right)>0$; (b) demands are homogeneous of degree zero in prices and income; (c) the Slutsky substitution matrix $S=\frac{\partial D}{\partial P^{\prime}}+\frac{\partial D}{\partial I} D^{\prime}$ is symmetric and negative semi-definite; and (d) income is strictly bigger than expenditures on the subset of the target foods, $P^{\prime} D\left(P^{\prime}, P_{O}{ }^{\prime}, I\right)<I$. The LinQuad Marshallian demand equations are

$$
D=\varepsilon+V P+\chi\left(I-\varepsilon^{\prime} P-\frac{1}{2} P^{\prime} V P\right),
$$

where $\chi, \varepsilon$ and $V$ are parameters to be calibrated. Symmetry of the Slutsky substitution matrix is 
imposed by setting $v_{i j}=v_{j i}$. The fact that the expenditure on target foods is smaller than income is always guaranteed. The Marshallian own- and cross-price elasticities are

$$
\left\{\begin{array}{l}
\eta_{i i}^{M}=\left[v_{i i}-\chi_{i}\left(\varepsilon_{i}+\sum_{k} v_{i k} P_{k}\right)\right] \frac{P_{i}}{D_{i}} \\
\eta_{i j}^{M}=\left[v_{i j}-\chi_{i}\left(\varepsilon_{j}+\sum_{k} v_{j k} P_{k}\right)\right] \frac{P_{j}}{D_{i}}
\end{array} .\right.
$$

With the values of the elasticities, income, price, and consumption levels, the demand system can be fully recovered.

\section{Welfare}

When a tax is applied on sweetener inputs or on final goods that are sweetener intensive, the negative effects of the taxes affect consumers' consumption and welfare. But there are also positive effects on consumers' health conditions through reduced consumption of sweetenerintensive products. Consumers would lose from higher prices of sweetened foods as consumer surplus is decreased, but the consumers' health conditions would improve as they choose the healthier substitutes. For example, instead of normal soft drinks, consumers may drink non-sugar and low-calorie drinks if the caloric sweeteners are taxed. In this study we only consider the negative effects from the market perspective. A limitation of this approach is that health status is not represented in the utility function. We abstract from the fact that consumers' health condition is an important component of their utility function.

In the following policy simulations, we set a certain decrease in added sweeteners consumption as the target of the tax policy and look for the optimal tax designs to achieve the desired goal. That is, we fix the reduction of added sweetener use and evaluate how the changes in sweetener intake are determined across foods and across income groups. In this way, we fix the health effects to be achieved through reduced intake of added sweetener as the equivalence basis of the policy target. Although this will overstate the negative welfare changes on final consumers, the positive health effect is hard to measure in the short run. We gauge the decrease of sweeteners consumption and measure the equivalent variation, EV, of the policy target. Most previous studies have overstated the regressive nature of the tax because they do not measure the health effects on consumers. This is also true of our study. We also measure the upper bound on the regressive nature of different taxes. In addition, the narrow focus on EV is not comprehensive because we do not address the impacts on producers' surplus and the government tax revenue.

Suppose the prices of target foods change from $P^{0}$ to $P^{1}$ because of changes in either inputs or final goods taxes. Then the EV derived from equation (9) shows the amount of money that consumers need to pay before a price increase to keep their utility level constant. That is,

$$
E V=\left(I-\varepsilon^{\prime} P^{1}-\frac{1}{2} P^{1} V P^{1}\right) \exp \left(\chi P^{0}-\chi P^{1}\right)-\left(I-\varepsilon^{\prime} P^{0}-\frac{1}{2} P^{0}{ }^{\prime} V P^{0}\right) .
$$

If the tax on the final products $\tau_{i}$ is changed, then

and

$$
\begin{gathered}
P_{i}^{1}=P P_{i}^{0}\left(1+\tau_{i}\right), \\
d \ln P_{i}=d \ln \left(1+\tau_{i}\right) .
\end{gathered}
$$

If the tax imposed on the sweetener inputs is changed, we have derived from the analysis of the 
food processing industry that $d \ln P P_{i}=\sum_{k} s_{i k} d \ln w_{i k}=\sum_{k} s_{i k} d \ln \left(1+t_{i k}\right)$, so

$$
d \ln P_{i}=d \ln P P_{i}=\sum_{k} s_{i k} d \ln w_{i k}=\sum_{k} s_{i k} d \ln \left(1+t_{i k}\right) .
$$

Then $P^{1}$ can be substituted into the EV equation to get the welfare changes.

We apply the LinQuad demand systems for all households and disaggregated income groups respectively to evaluate how to achieve the policy target of reducing the added sweeteners consumption by a fixed amount and minimize the consumer welfare loss. Two alternative approaches are used: taxing final sweetener-intensive goods, and taxing sweetener inputs. The consumption tax affects consumers through the price changes of final products. In contrast, the input tax affects the mix of inputs used by food processors and, ultimately, the final goods consumed.

\section{Disaggregated income groups}

To investigate the tax effects on different income groups, the LinQuad demand systems are modified by the variation of shifters $\varepsilon$ (the intercept of Marshallian demands). We assume the increase in income has the same marginal effects on the food demand for each of the $n$ disaggregated income groups; that is, the partial derivatives of demand with respective to income, $\chi$, are equal across the income groups.

The disaggregated food demands for each income group are

$$
\left\{\begin{array}{l}
D_{1}=\varepsilon_{1}+V_{1} P+\chi\left(I_{1}-P^{\prime} \varepsilon_{1}-\frac{1}{2} P^{\prime} V_{1} P\right) \\
D_{2}=\varepsilon_{2}+V_{2} P+\chi\left(I_{2}-P^{\prime} \varepsilon_{2}-\frac{1}{2} P^{\prime} V_{2} P\right) \\
\vdots \\
D_{n}=\varepsilon_{n}+V_{n} P+\chi\left(I_{n}-P^{\prime} \varepsilon_{n}-\frac{1}{2} P^{\prime} V_{n} P\right)
\end{array} .\right.
$$

Meanwhile, the own- and cross-price elasticities for all households are weighted averages of own- and cross-price elasticities for disaggregated income groups, which satisfy the following condition:

$$
\eta_{i j A l l}^{M}=\frac{D_{i 1}}{D_{i A l l}} \eta_{i j 1}^{M}+\frac{D_{i 2}}{D_{i A l l}} \eta_{i j 2}^{M}+\cdots+\frac{D_{i n}}{D_{i A l l}} \eta_{i j n}^{M}
$$

where $\eta_{i j A l l}^{M}, \eta_{i j 1}^{M}, \eta_{i j 2}^{M} \cdots \eta_{i j n}^{M}$ are the cross-price elasticities of food demand $i$ to food price $j$ for all households and disaggregated income groups. They can be expressed as equation (10).

Under the assumptions that $V_{1}=V_{2}=\cdots=V_{n}=V$, equations (15) and (16) can be solved simultaneously to get the values of the parameter $\varepsilon$ for the linear price term and the parameter matrix $V$ for the quadratic price term for each of the disaggregated income groups. The shifter $\varepsilon$ contains two pieces of information. One is a common component across the income groups, which reflects the linear component of consumers' response to the price changes; the other includes the consumers' demographic characteristics in income levels. So with the common component in $\varepsilon$ and the assumption that the $V$ and $\chi$ are equal across the income groups, we establish that all consumers have equal price and income preferences. What makes the difference 
in response is only the demographic characteristics variation. The welfare evaluations are given as in equation (11) for each of the income groups. The differences across disaggregated income groups come from differences in income and the value of parameters.

\section{Data and Calibration}

Data used come from several sources. Estimates for input cost shares are from the 2002 Economic Census Industry Series Reports. Other data are on consumption (food availability) and the demand parameters used to calculate the LinQuad demand system. The data calculations are described in more detail in the following sections.

\section{Production of sweetener-intensive foods}

To measure the cost share of sweeteners in the food production process, we use data on the materials consumed by each industry from the Economic Census Industry Series Report (U.S. Census Bureau, 2004). This series report comes from the Census Bureau and is based on an industry survey collected every five years. The 2002 Economic Census Industry Series Reports (Manufacturing) was the latest survey available at the time of this analysis. Manufacturing industries are identified by the 2002 North American Industry Classification System (NAICS). The industry reports include quantity and cost of materials put into production by establishments classified in the specified industry.

\section{Material cost shares}

Data in our study are based on the 2002 Economic Census. All dollar values presented are expressed in 2002 dollars. From the Economic Census Industry report, we identify four sweeteners that are used in the food processing industries: Sugars (sugar from cane and beet), Corn Sweeteners, Other (caloric) Sweeteners, and Artificial Sweeteners. Table 1 provides the material code categories used in the classification into the four sweetener groups.

The cost shares of sweeteners in the total cost of food processing are approximated from the respective shares in the value of shipments from the component materials consumed. Some caveats are in order regarding this approximation.

\section{Intermediate materials used}

As related industries always represent successive production stages of a final product, the products of some industries are used as materials by other industries. In addition to the sweetener inputs used directly, sweeteners are also used in intermediate products. Table 2 presents categories of sweetener-intensive intermediate materials. In the table, the major sweetenerintensive intermediate materials are aggregated into eight groups: fluid milk; cheese; dry, condensed and evaporated milk; ice cream and yogurt mix; prepared mixes; flour; liquid beverage base; and chocolate. As an example, the manufacturing industry "Fluid milk manufacturing” (NAICS 311511) uses as inputs the sweetener-intensive intermediate materials ice cream mix, sherbet mix, yogurt mix, and chocolate. These sweetener-intensive intermediate materials contain relatively large amounts of sugar, corn sweeteners, artificial sweeteners, and other sweeteners. When calculating the cost share of sweeteners in the fluid milk manufacturing industry, the sweeteners' value contained in these sweetener-intensive intermediate materials is included in addition to the direct use of the sweeteners shown in Table 1.

To approximate what kind of sweeteners and how much of each are contained in the 
sweetener-intensive intermediate materials, we matched the eight aggregated intermediate materials groups to the NAICS industries by using a representative industry among the NAICS industries for each of the intermediate materials products. The matched intermediate materials product groups and representative industries are shown in Table 2. Detailed matching between the sweet-intensive intermediate products and the NAICS material codes are shown in Appendix A. Once the sweeteners' ingredient shares in each of the eight intermediate materials groups were calculated, they were applied to all other industries that have the specific intermediate materials as an ingredient. For example, the sweeteners' share of the "Fluid milk manufacturing" product group (NAICS 311511) was used as proxy for the sweeteners' ratio of fluid milk used as ingredient input in other industries.

\section{Targeted sweetener-intensive foods}

Next, we calculate the value of sweetener inputs in food industries and determine the most sweetener-intensive food industries. The products of the industries, the foods, are the focus of our analysis. Table 3 lists the nine target sweetener-intensive foods and the food industries to which they are matched. Some foods could only be matched to part of a food industry group. This partial matching leads to the decomposition of these industries used in the later analysis. For example, the final product group "Juice" is matched to the segment of "Frozen juices, aides, drink, and cocktail” in the "Frozen fruit, juice, and vegetable manufacturing” (NAICS 311411) industry sector and the segment of "Canned fruit juices, nectars, and concentrates and fresh fruit juices and nectars” in the "Fruit and vegetable canning” (NAICS 311421) industry sector.

\section{Proportion of products to direct consumption}

Some of the outputs of the food manufacturing industries are consumed directly by consumers while others are chosen as inputs by manufacturers from other food industries. The proportion of products going to direct consumption for each food industry is also provided in Table 3. The eight corresponding representative industries of the sweetener-intensive intermediate materials have proportions less than $100 \%$. For example, only $16.42 \%$ of the output of the manufacturing industry "Flavoring syrup and concentrate manufacturing" (NAICS 311930) is consumed directly by consumers; the remaining $83.58 \%$ of the output goes to the "Soft drink manufacturing" industry as ingredients. For refined sugar, the manufacturing industry "Cane sugar refining" (NAICS 311312) and "Beet sugar manufacturing” (NAICS 311313) plus the import of refined sugar make the total refined sugar supply. Consumers consume refined sugar directly and indirectly when manufacturers in other industries use refined sugar as ingredients. The proportion of refined sugar that consumers consume directly is estimated to be 58.02\% (U.S. Census Bureau, 2004). Other sweetener-intensive food industries have none or only a small proportion of their outputs used as inputs.

\section{Value of sweeteners and cost share}

Table 4 provides the data for the values and shares of the sweeteners in the nine target sweetener-intensive foods (those listed in Table 3). The numbers in parentheses show the distribution of the sweeteners among the nine target sweetener-intensive foods based on their values. Note that $68.51 \%$ of the Sugars and $66.61 \%$ of the Artificial Sweeteners contained in the nine target sweetener-intensive foods are taken by the final food product group "Sweetener products"; $54.36 \%$ of the Corn Sweeteners contained in the nine target sweetener-intensive foods is taken by the final food product group "Soft drink"; and 44.93\% of the Other Sweeteners 
contained in the nine target sweetener-intensive foods is taken by the final product group "Condiments/Spices." Among all the sweeteners contained in the nine target sweetener-intensive foods, "Sweetener products" includes nearly one-half of the sweeteners. And both "Soft drink" and "Breakfast cereal/Bakery" hold nearly one-fifth of the total sweetener value share across the nine food groups. These three groups of final products are the "sweetest" (most sweetener intensive) foods. The quantities of sweeteners in the nine target sweetener-intensive foods are the result of dividing the values of the sweeteners by their prices as shown in Appendix B. Table 5 provides the calculated cost shares of the four sweeteners in the nine target foods.

\section{Consumption}

The 2002 Economic Census Industry Series Reports (Manufacturing) provide the value of shipments for different food industries. These data are compiled from the perspective of production. To analyze the component ingredients from the perspective of consumption, some adjustment is needed. Specifically, the reported data on food disappearance (USDA/ERS, 2008b) needs to be matched and calibrated to the consumption data. We calculate the ratio of food disappearance data to the production data from the food availability dataset for the different foods and use the adjustment ratio $\lambda$ to convert the value of shipments from production $y$ to consumption $D$ :

$$
D=\lambda y \text {. }
$$

The values of the adjustment ratio $\lambda$ are listed in Table 3 , and the calculation of the adjustment ratios from the food availability data is discussed in Appendix C. For food groups that do not have matches in the food availability dataset, the adjustment ratios were set to one. Values greater than one imply imports to the sector. The sweeteners usage in the manufacturing sector can also be converted to sweeteners consumption by the consumers using the same adjustment ratio $\lambda$.

\section{Demand parameters}

To recover the parameter values in the LinQuad demand system, measures of the income elasticities $\eta_{i I}$, own-price elasticities $\eta_{i i}^{M}$, cross-price elasticities $\eta_{i j}^{M}$, income $I$, prices $P_{i}$, and consumption levels $D_{i}$ are needed. Since we carry out calibration for all households and for households by disaggregated income groups, data for these two sets of household aggregates are discussed separately.

\section{Data for all households}

(1) Income elasticities $\eta_{i I}$ and price elasticities $\eta_{i i}^{M}, \eta_{i j}^{M}$

The income and price elasticities were obtained from two sources: the USDA/ERS Commodity and Food Elasticities Database (2008a) and Chouinard et al. (2010). The USDA/ERS database is a collection of elasticities mostly from academic and government research, as published in journals and working papers. Chouinard et al. provides detailed elasticities for dairy. We take the average of the elasticities for each of the food groups, after removing those elasticities that were outside two standard deviations of the mean level of the elasticities for the food group. The summary statistics for the own-price elasticities and income/total expenditure elasticities obtained in this way are listed in Table 6. The food groups "Cheese," "Processed fruits and vegetables," and "Condiments/Spices” turn out to be price elastic while others are price inelastic. The food groups "Ice cream/yogurt” and "Soft drink" have negative income elasticities, which 
indicates that they are inferior goods.

The cross-price elasticities from the same sources are listed in Table 7. All the available cross-price elasticities are very small in absolute value, which means the substitutability or complementarily among the final products will be limited.

\section{(2) Income I}

The 2002 Consumer Expenditure Survey (CEX) (Bureau of Labor Statistics, 2002) reports the total number of households represented in the survey as 112,108,000, and the average household income level after taxes as $\$ 46,934$. Based on these values, the annual income for all the households is $\$ 5.26$ trillion.

\section{(3) Price $P_{i}$}

All final food prices are initially set at $\$ 1$ per unit. The consumption units are unknown but results are independent of the price normalization.

\section{(4) Marshallian demands $D_{i}$}

As all the prices are set at $\$ 1$ per unit, we can use the adjusted value of shipment of the foods in dollar values as physical quantities.

\section{Data for disaggregated income groups}

The 2002 CEX provides data on income and expenditures for different food groups for households disaggregated by quintiles of income. These data provide the disaggregated annual income and food expenditures (Table 8). The values of at-home food expenditures in the CEX were used to distribute the total adjusted industry level value of shipments in the 2002 Economic Census Industry Series Reports (Manufacturing) across the five income groups. The matchup between the food categories in the two surveys is detailed in the footnote to Table 8. Although there are some differences between the composition of food at home and food away from home across the food categories, we assumed that the expenditure distribution on these nine target food groups are the same for at-home and away-from-home expenditures. There are no data for food away from home at a disaggregated (food group) level in the CEX. All the food prices are initially set at \$1 per unit as was done in the "all households" scenario.

\section{Production technology in food industries}

As shown in Table 5, the cost shares of sweeteners, including Sugars, Corn Sweeteners, Other Sweeteners, and Artificial Sweeteners used in the manufacturing process account for less than $4 \%$ (except for the "Sweetener products" industry for which they account for $12.37 \%$ ) of the total costs of production. We integrate all other materials used in the manufacturing process into one group called “All Other Inputs.” For most sweetener-intensive food industries, this aggregate represents more than $96 \%$ of the total costs. The aggregation of the other inputs is done to focus on sweeteners and abstract from what happens to other inputs.

The five-by-five matrix of input price elasticities for sweetener-intensive industries is developed from industry estimates provided by Goodwin and Brester (1995). The diagonal elements, which represent the own-price elasticity of sweeteners are set to -0.48. In the upper triangle elements, the cross-price elasticity of Sugars with respect to Corn Sweeteners is set to 0.30; if there is some usage of Other Sweeteners and Artificial Sweeteners, the cross-price elasticities of Sugars and Corn Sweeteners with respect to Other Sweeteners are both set to 0.01; and the cross-price elasticities of Sugars, Corn Sweeteners, and Other Sweeteners with respect to Artificial Sweeteners are all set to 0.005. The lower triangle elements are derived from the upper triangle elements because their ratios are proportional to their cost shares' ratio based on the 
definition of Hessian matrix in the production. Appendix D provides a table that summarizes the values.

Once the first four columns of the input price elasticity matrix are set, the last column, which represents the price elasticities of sweeteners to "All Other Inputs," is derived using the homogeneity property of the Hessian matrix from the output-constant cost function of food manufacturers with respect to prices. The concavity curvature of the cost function requires that the Hessian matrix be negative semi-definite. The above rules constrain elasticity values when some sweeteners' cost shares are very small or equal to zero. In this situation, the corresponding elements in the upper-triangle of the input price elasticity matrix need to be set to smaller values to satisfy the homogeneity condition.

There is no usage of Other Sweeteners in the final products "Milk" and "Ice cream/yogurt." For "Milk," the cross-price elasticities of Sugars and Corn Sweeteners with respect to Other Sweeteners are both set to 0.00007, the cross-price elasticities of Sugars, Corn Sweeteners, and Other Sweeteners with respect to Artificial Sweeteners are all set to 0.00014. For "Ice cream/yogurt," these two numbers are set to 0.0002 and 0.0004 . If there is neither Other Sweeteners nor Artificial Sweeteners used, the sweeteners' cross-price elasticities in the upper triangle are all set to 0.0005 except the one between Sugars and Corn Sweeteners. Although some sweeteners are not used in the manufacturing process, their cross-price elasticities are set to non-zero values because the manufacturers' choices of the sweeteners are determined by the relative price of inputs. All the sweeteners have the potential to be used once the relative prices of inputs reach some levels. Besides that, the fact that the integrated "All Other Inputs" take a large proportion of the total cost leads to the outcome that its own-price elasticity is very small.

\section{Results}

\section{Calibration of demand systems}

We calibrate six LinQuad demand systems. One is for all households with nine sweetenerintensive foods using elasticities from Tables 6 and 7. The other five systems for quintile income groups are solved by utilizing the partial derivative of demand to income for all households and setting the parameter matrix of the quadratic price term to be equal among different income groups. Based on equations (9)-(10) and equations (15)-(16), we get the results of parameter values for the six LinQuad demand systems. The parameter for the income term in the demand, $\chi$, is the same for all households and quintile income groups. The parameter for the linear term of the price for all households, $\varepsilon_{\text {All }}$, equals the summation of those for quintile income groups $\varepsilon_{1}$ to $\varepsilon_{5}$. By construction, this parameter includes not only the information of the response to price but also that of the demographic characteristics. The parameter matrix for the quadratic term of the price for all households $V_{\text {All }}$ is five times that for quintile income group $V$, also by construction, so consumers behave the same way in terms of price and income preferences across the quintile income groups on an individual basis. The values of the parameters in the LinQuad demand system are provided in Appendix E.

With these parameters, the Marshallian price elasticity matrix for all households and disaggregated income groups are recovered. The one for all households is displayed in Table 9. Separate Marshallian price elasticity matrices for disaggregated income groups are provided in Appendix F. The absolute values of the own-price elasticities for each food category are monotonically decreasing from the lowest $20 \%$ quintile to the highest $20 \%$ quintile income 
group, which indicates that poor consumers are more sensitive to the price variations than rich consumers. The parameters are used in the calculation of the demand for the final products, the sweeteners and the welfare evaluation.

\section{Simulation and welfare evaluation}

To compare the efficiency and regressive nature of the two tax instruments, the two taxes are designed to reduce the quantity of all sweeteners (sugar equivalent) ${ }^{1}$ that all households consume by $10 \%$ (around 13.13 grams per capita daily sugar equivalent added sweeteners consumption, which contain 52.54 calories) and to minimize the associated market welfare loss to all households. The reduction of sweetener quantity is the basis of equivalence to compare the scenarios. The parameter values from the LinQuad calculation allow simulation of sweeteners consumption changes caused by policy (tax) changes, and estimation of the corresponding changes on food demand, sweeteners consumption, and EV. We simulate four types of policy shocks: a tax on the price of final products, a tax on the price of caloric sweeteners, a tax on the price of all sweeteners, and tax on the price of individual sweeteners.

Tax on final products. First, we consider the case when an ad valorem consumption tax is imposed on the nine categories of sweetener-intensive final products as discussed in Table 3. To reach the goal of reducing the sugar equivalent quantity of all sweeteners that all households consume by $10 \%$ and minimize the associated welfare loss of all households, the tax rate is estimated to be $39.30 \%$ on the final product group "Sweetener Products" and at rates that are much smaller or negligible on the other eight final products. This is determined by the fact that $47.82 \%$ of all sweeteners contained in the nine sweetener-intensive foods are in this particular food group. Table 10 shows the initial per capita food demand, real expenditure, sweeteners consumption, the percentage change for each measure, and the estimated market welfare change on nine foods for all households with the simulated tax imposed on the price of final products.

Consumers on average initially spend more than $\$ 100$ per capita on each of the food groups “Breakfast cereal/Bakery," "Soft drink," “Condiments/Spices,” and “Milk” before a tax is imposed. These four foods represent over $65 \%$ of the total per capita real expenditure on the nine sweetener-intensive foods (20.63\%, $16.31 \%, 14.41 \%$, and $13.83 \%$, respectively). Demand decreases the most $(-19.82 \%)$ in the group of "Sweetener products" with the simulated tax rate imposed on the price of final products. The demand for "Condiments/Spices" also decreases by a small amount. Demand for all other foods increases slightly through substitution effects.

Consumers initially consume 61.90 pounds of Sugars, 54.81 pounds of Corn Sweeteners, 2.86 pounds of Other Sweeteners, and 0.54 pounds of Artificial Sweeteners. The initial per capita value of sweeteners consumption was about $\$ 22.66$. Of that value, 60.90\% was for Sugars, $32.26 \%$ for Corn Sweeteners, 4.15\% for Other Sweeteners, and 2.69\% for Artificial Sweeteners. Since the tax is imposed on the price of final products and does not cause any substitution among the sweeteners in the manufacturing process, the sweeteners consumed change at the same rates as the final products consumed.

\footnotetext{
${ }^{1}$ The quantity of total sweeteners is converted into sugar equivalent based on the sweeteners' caloric content. Cane sugar and beet sugar are relatively pure sucrose. They have approximately 4 kcal per gram. HFCS is the primary corn sweetener in the United States. It has approximately $3 \mathrm{kcal}$ per gram. As a representative of Other Sweeteners, honey has approximately $3 \mathrm{kcal}$ per gram. Aspartame is the most popular artificial sweetener currently used in the U.S. food industry. It has approximately 4 kcal per gram.
} 
Overall, the quantities of all sweeteners (sugar equivalent) consumed decrease by $10 \%$ by design. The quantity of Sugars consumed decreases by $13.39 \%$ and the Artificial Sweeteners by 13.14\%. These rates of decrease are much higher than the decrease of quantities of Corn Sweeteners and Other Sweeteners consumed because the tax falls mostly on the final product group "Sweetener products," and this food group has the highest rank in the distribution of Sugars and Artificial Sweeteners. Per capita real expenditure on all nine foods increases by $1.86 \%$ from the baseline condition of $\$ 726.13$ per capita in 2002 . The per capita welfare loss caused by the tax is $\$ 31.00$, which represents $0.17 \%$ of the income.

The corresponding changes to the above-simulated tax on the price of final products were also computed for the five quintile income groups, as displayed in Appendix G. All five income groups have large decreases in the demand for food category "Sweetener products," small decreases in the food category "Condiments/Spices," and increases in the other seven food categories. The absolute value of the rates of change in most food categories follows a monotonically decreasing trend from the lowest $20 \%$ quintile to the highest $20 \%$ quintile because low-income consumers respond more strongly to price variations than do consumers with high income. The decrease for all households in the food category of "Sweetener products" is $19.820 \%$. It is the average of the individual groups' decreases from $29.277 \%$ for the highest income group to $14.032 \%$ for the lowest income group. But for other food categories, the differences of demand rates of change across income groups are relatively small. For example, the rates of change in demand for "Soft drink" remain almost flat throughout the income groups.

Since the initial consumptions of final products are not monotonically increasing or decreasing across the five income groups, the initial consumption of sweeteners included in the foods are not monotonic across the groups either. However, the drop of the sugar equivalent of the quantity consumed of all sweeteners decreases monotonically from the lowest quintile income group (with a rate of $-13.10 \%$ ) to the highest quintile income group (with a rate of $-6.26 \%$ ) to achieve an average of $-10 \%$ for all households. Sugar always ranks first among the four types of sweeteners in the rate of consumption change, followed by Artificial Sweeteners. For each type of sweetener, the drop in the sweetener's quantity decreases monotonically from the lowest quintile income group to the highest quintile income group. Table 11 displays the sweeteners' consumption quantity changes for all households and then the disaggregated income groups under different tax policy situations.

Table 12 compares the real expenditure change and market welfare loss for all households and quintile income groups with the various tax scenarios. Although the per capita real expenditures for the target sweetener-intensive foods are not monotonic across income groups, the changes induced by the consumption tax increase from $0.51 \%$ for the lowest quintile income group to $2.70 \%$ for the highest quintile income group monotonically, as shown in Table 12. Although the per capita real expenditure increases the most for the highest income group and the per capita EV is highest with the highest income group, the welfare loss represents $0.60 \%$ of income for the lowest quintile income group while it represents only $0.10 \%$ of income for the highest quintile income group. The proportion of the market welfare loss in income for the lowest income group is six times that of the highest income group, which indicates that this consumption tax is regressive but its overall impact is small.

Finally, we also compare this tax with a tax on soft drinks, which is often considered in policy debates. To reduce the sweetener consumption by $10 \%$, the consumption tax on soft drinks is $63.19 \%$. The associated per capita EV is $\$ 52.92$, which takes $0.28 \%$ of income. Hence it is clearly less efficient but of the same order of magnitude. 
Tax on caloric sweetener inputs combined. Next, we simulate a tax imposed on caloric sweetener inputs. Under the assumptions that the processor's markup is constant and consumer demand is not perfectly elastic, the tax on the price of sweeteners is fully passed on to consumers of sweetener-intensive foods through higher output prices. The changes for all households in food demand, real expenditure, sweeteners consumption, and welfare are shown in Table 13. To reach the target of reducing the sugar equivalent quantity of all sweeteners that all households consume by $10 \%$ and minimizing the associated welfare loss of all households, the tax rates are estimated to be $27.47 \%$ on Sugars, $42.95 \%$ on Corn Sweeteners, and a very small rate on Other Sweeteners. This simulated tax will have the most effect on the final price of "Sweetener products" and "Soft drink" because these two final foods hold $68.51 \%$ of the Sugars and 54.36\% of the Corn Sweeteners that are contained in the nine sweetener-intensive food categories. With the highest new consumer prices, these two food categories have over a $1 \%$ decrease in their demand. Other food categories have smaller decreases compared to these two categories.

With different tax rates on different types of caloric sweeteners, the variation of the sweeteners' price leads food manufacturers to make adjustments in their production process in terms of scale and substitution effects. Scale effects result from the consumers' demand adjusting to higher unit cost and hence higher consumer prices. Further, the variation of sweetener input prices leads food processors to substitute away from expensive sweeteners to cheaper sweeteners and other inputs.

Sugars and Corn Sweeteners used in each food category decrease and the Other Sweeteners and Artificial Sweeteners increase. There is some decrease in the usage of Artificial Sweeteners in the "Sweetener product" group. The quantity of Sugars declines the most in the "Sweetener products" and the quantity of Corn Sweeteners declines the most for the "Soft drinks.”

The contribution of "Soft drinks" in aggregate-sweetener use falls the most. "Processed fruits and vegetables," "Juice," and "Sweetener products" see their contribution fall by more than $10 \%$. Accounting for the sweetener change in all nine foods together, the Corn Sweeteners quantity decreases the most (by 12.41\%), followed by Sugars quantity (by 8.95\%). The quantities of Other Sweeteners and Artificial Sweeteners increase, as they are substitutes to the taxed sweeteners. In sum, the sugar equivalent sweetener quantity is reduced by $10 \%$, again by design.

The use of Sugars and Corn Sweeteners decreases because of the increase in their prices. However, the cost of all four types of sweeteners goes up as the increase in prices exceeds the drop in quantities because the inputs are price-inelastic. This tax on Caloric Sweeteners causes the per capita real expenditure to increase $0.27 \%$, at a rate smaller than occurs when the tax is on the price of final products. The per capita EV is $\$ 5.98$ (or $0.032 \%$ of the per capita income), which is also smaller than the one caused by the consumption tax on the price of final products.

Detailed simulation results on the five-quintile income groups with the tax on Caloric Sweeteners (Appendix $\mathrm{H}$ ) show that the consumption of all nine sweetener-intensive foods falls for each of the income groups. The decreases in "Sweetener products" and "Soft drink" are much higher than for the other food categories. The comparison across the five income groups shows that for most food categories, demand drops less as income goes up as a consequence of the difference in the price elasticities for the different income groups. The sugar equivalent quantity of added sweeteners consumed by all households is reduced by $10 \%$, with an average decrease of $10.45 \%$ for the lowest quintile income group, $10.19 \%$ for the second quintile, $10.04 \%$ for the 
third quintile, $9.90 \%$ for the fourth quintile, and 9.73\% for the highest quintile. The quantities of Sugars and Corn Sweeteners used in all nine foods decrease while the quantities of Other Sweeteners and Artificial Sweeteners increase. The absolute values of the rates of change in quantities of Sugars and Corn Sweeteners decrease monotonically from low-income to highincome groups, while the absolute values of the change rates in quantities of Other Sweeteners and Artificial Sweeteners increase in an ascending order from low-income to high-income groups. The expenditures on all four types of sweeteners consumed all rise because these derived demands are price-inelastic.

The changes on the real expenditure and market welfare with a tax on Caloric Sweeteners are also provided in Table 12. The per capita real expenditure changes move at ascending rates from $0.007 \%$ for the lowest income group to $0.43 \%$ for the highest income group. The highest income group has the largest market welfare loss. In per capita terms, the EV is small. It takes $0.12 \%$ of the income of the lowest income group and $0.02 \%$ of the income of the highest income group. The proportion of the market welfare loss in income for the lowest income group is six times that of the highest income group, just as was the case when the consumption tax was imposed. The simulated tax on Caloric Sweeteners is also regressive, as it puts a greater burden on poor consumers. However, the welfare loss is much smaller in the case of the input tax than in the case of the consumer tax. Hence, the tax burden on the poor is reduced with the input tax.

Tax on individual sweetener input. Finally, we consider the case in which the tax is sequentially imposed on individual sweeteners. We are motivated to investigate the scenarios of taxing Sugar and Corn Sweeteners. The health literature often discusses whether the intake of sugar and HFCS causes obesity, hence, the focus on these two major sweeteners. Table 14 shows per capita food demand, real expenditure, sweetener consumption, and the market welfare changes of nine foods for all households with a tax imposed on Sugars or Corn Sweeteners to reduce the sugar equivalent quantity of all sweeteners by $10 \%$ and minimize the associated market welfare loss. It turns out that a tax of $61.25 \%$ on the price of Sugars or a tax of $156.85 \%$ on the price of Corn sweeteners is needed to reach the $10 \%$ reduction target.

With the application of the tax on Sugars, manufacturers substitute from Sugars to other types of sweeteners. This case is motivated by the ongoing debate alleging that some sweeteners are healthier than others. HFCS has been heavily targeted in some debates as a major source of health problems. These claims have not been confirmed, but it is still interesting to look at the consequences of singling out a caloric sweetener with a tax. "Sweeteners products" consumption exhibits the highest decrease $(-2.63 \%)$ because it uses Sugars the most. Considering all the Sugar in nine food categories together, the consumption quantity of Sugars decreases $22.09 \%$ while the associated expenditure increases. Other types of sweeteners exhibit increases in both their quantities and values. The per capita real expenditure on all nine foods increases by $0.46 \%$. The per capita EV is about $\$ 6.65$ and it takes $0.035 \%$ of consumer income.

With the application of the tax on Corn Sweeteners, manufacturers switch away from Corn Sweeteners to other types of sweeteners. "Soft drink" has the highest (3.02\%) decrease in its food demand because it uses Corn Sweeteners the most. Counting all the Sugars in nine food categories together, the consumption quantity of Corn Sweeteners decreases (37.64\%) while its consumption value increases. Other types of sweeteners increase in both their quantity and value. The per capita real expenditure of all nine foods increases by $0.09 \%$. The per capita EV is about $\$ 6.90$ and it takes $0.037 \%$ of income.

In the case of an individual tax on the price of the Sugars input, results for the 
disaggregated income groups show differences across the income groups (Appendix I). The absolute value of the change in food demand goes down as income goes up. For the sweeteners, the absolute values of the rates of change in quantities of Sugars decrease monotonically from low-income to high-income groups, while the absolute values of the proportional changes in quantities of Corn Sweeteners and Other Sweeteners increase in ascending order from low- to high-income groups. The rates of change in quantities of Artificial Sweeteners increase from the negative values for the lowest income group to positive values for the highest income group. The values of all four types of sweeteners consumed rise. When a tax is applied to the price of Corn Sweeteners instead of Sugars, the changes are similar to those for changes in the price of Sugars except that the rates of change in quantities of Sugars are not monotonic as shown in Appendix J. The values of all four types of sweeteners consumed rise.

The real expenditure and market welfare changes are shown in Table 12 along with the outcomes for other cases. With the tax on Sugars, the real expenditure increases monotonically from $0.25 \%$ for the lowest income group to $0.60 \%$ for the highest income group. With the tax on Corn Sweeteners, the real expenditures decrease for the lowest $20 \%$ and second $20 \%$ quintile income groups but increase for the other three quintile income groups. For the market welfare evaluation, the absolute values of the per capita EV under both situations have a U-shaped trend across the income groups, but the fraction of $\mathrm{EV}$ in income decreases from the lowest income group to the highest income group. The tax on individual sweeteners is regressive too, but the welfare loss to the poor is much lower than in the case of the consumer tax.

\section{Sensitivity Analysis}

\section{Doubling the sweetener reduction}

All the above simulations are designed to reduce the sugar equivalent quantity of all sweeteners by $10 \%$. In order to test whether the results are linear when the policy target changes, we simulate a 20\% reduction (around 26.27. grams per capita daily sugar equivalent added sweetener consumption, which contain 105.07 calories) and minimize the associated market welfare loss (Appendix K).

For the case of a $20 \%$ reduction, the tax on the price of the final products would need to be $78.60 \%$ for the "Sweetener products" food group, and smaller numbers for other food categories. This causes a 39.64\% decrease in "Sweetener products" consumption, a 0.03\% decrease in "Condiments/Spices" consumption, and some increases in other foods consumption. We find that the simulated tax and the food demand changes are around twice those that occur when the sugar equivalent quantity of all sweeteners is reduced by $10 \%$. The quantities of all four types of sweeteners fall. Sugars and Artificial Sweeteners fall more than do Corn Sweeteners and Other Sweeteners. The proportional decreases are about double those of the rates when the sugar equivalent quantity of all sweeteners is reduced by $10 \%$. But the relative change of the real expenditure does not vary much (from 1.86\% to 1.85\%) when the target goes from a $10 \%$ to a $20 \%$ reduction. The per capita EV is about $\$ 55.18$ and is less than twice of the per capita EV of $\$ 31.00$ when the goal is a $10 \%$ decrease. It is about $0.29 \%$ of consumer income.

Doubling the targeted reduction in sugar equivalent quantity of all sweeteners requires a tax of $\mathbf{8 0 . 5 9 \%}$ on Sugars, $117.12 \%$ on Corn Sweeteners, and a small rate on Other Sweeteners. These values are almost three times those of the tax rates with the initial target of a $10 \%$ reduction of sweetener consumption. The combined results of changes in the tax rates are more than twice those of the rates when the sugar equivalent quantity of all sweeteners is reduced by 
$10 \%$ except for Corn Sweeteners, whose proportional decrease is less than doubled. The nonlinearity in results exists because sweetener input taxes are weighted by sweetener cost shares in imposing the effects on the price of final products, and because of further effects on the demand of food and sweetener consumption. The relative changes of the real expenditure, EV, and fraction of EV in income are all more than twice those that occur under the $10 \%$ reduction target. Per capita EV is about $\$ 13.95$ and it is about $0.074 \%$ of income.

\section{Parameter assumptions}

For the simulation results on sweetener consumption, change comes from two sources: one is the substitution among final products chosen by consumers; the other is the substitution among sweeteners in the production process managed by the manufacturers. The real values of the substitutability among sweeteners are unknown so all of our simulations are based on the values we assumed for the input price elasticities. To test how the results depend on the input elasticities, we decreased all the cross-price elasticities between sweeteners by one-half in the uppertriangles of the price elasticities matrix for each of the nine food industries while keeping the own-price elasticities as before (Appendix L). In simulating the reduction in sugar equivalent quantity of all sweeteners by $10 \%$ with the new elasticities (Appendix M), we find that the tax rates on Caloric Sweeteners decrease only a little compared with the tax rates before changing the input elasticities (Table 13). The results are similar for other configurations of the taxes (taxing All Sweeteners, Sugars, or Corn Sweeteners). From these simulations, we determine that if the substitutability among sweeteners is decreased by half, the tax required to reach the desired goal is reduced, but only a little. The input price elasticities play a less important role than do the demand price elasticities for the final products. The simulation results do not depend much on the parameter values assumed. Computations and approximations in the simulations are discussed in Appendix N. Appendixes O, P, Q, and R also provide the simulation results and sensitivity analysis of taxing on the price of All Sweeteners. There is not much difference between the scenarios of taxing All Sweeteners and taxing Caloric Sweeteners.

\section{Summary and Discussion}

In this paper we analyzed the use of consumption and input taxes as instruments to reduce sweetener intake and derive their welfare effects on different income groups. We applied the LinQuad approach to a partial demand system for selected food consumption in the United States in 2002. Nine sweetener-intensive food groups were constructed for all households from the 2002 Economic Census Industry Series Reports (Manufacturing). Because of the possible different consumption patterns across income levels, we divided all households into five quintile income groups. We calibrated demand systems for all households and for each income group. Sugars, Corn Sweeteners, Other Sweeteners, and Artificial Sweeteners are the four types of sweeteners considered. Substitution among sweeteners takes place when a tax is imposed on some sweeteners. We compared two ways to reach the target of reducing the sugar equivalent quantity of all sweeteners by a certain amount while minimizing the loss of consumer welfare from the taxes.

Taxing the price of final products intensive in sweeteners leads to the largest tax, a decrease in the demand of "Sweetener products," and all four types of sweeteners decrease in quantity. Taxing Caloric Sweeteners as inputs causes relatively large decreases in final consumption of final goods among "Sweetener products" and "Soft drink" and decreases in the 
quantities of Sugars and Corn Sweeteners used in final goods. Taxing individual sweeteners only lowers the quantity of the particular sweetener that is taxed. Imposing a tax on Sugars and on Corn Sweeteners causes the demand in "Sweetener products" and "Soft drink" to fall the most. And these results apply to each of the income groups. Thus, the results of the policy may vary depending on which food category a policymaker may target or which sweetener may be targeted.

The consumer welfare impacts of various taxes were measured and compared. We showed that increasing the price of the sweetener-intensive foods, whether by taxing the final products or by taxing sweetener components, would reduce consumer welfare by a relatively small magnitude: $\$ 31.00$ per capita EV with a consumption tax, and \$5.98 per capita EV with a Caloric Sweeteners input tax. From an overall perspective, no matter which tax instrument is applied, the lowest income group is always the group most affected and the highest income group the least affected. Based on these findings, we conclude that both the tax on the price of sweetener-intensive final products and the tax on the sweeteners are regressive.

All the existing studies to date, including the one described in this paper, over-estimate the problem of regressiveness because the reduction in sweetener consumption is relatively more significant for the low-income group than for the high-income group. So the poor benefit more than the rich if health status is incorporated into the welfare evaluation. A possible way to correct the regressiveness would be to impose decreasing weights on the EV from the low-income group to the high-income group when designing the policy target. With a higher weight on the EV of poor households, the aversion to regressive schemes is better addressed.

Overall, the tax on sweeteners has a smaller impact on consumers' real expenditures and market welfare than does the tax on final products. A tax on Caloric Sweeteners causes the smaller loss to consumers on a per capita basis (\$5.98) compared to taxing all sweeteners. A tax on Sugars or Corn Sweeteners has a higher effect, but not much higher (\$6.65 and \$6.90 respectively). A tax on the price of final products poses a welfare loss burden about five times as great on all households and for each income group compared with the tax on Caloric Sweeteners. So taxing Caloric Sweeteners is the most efficient way to achieve the policy target.

It should be noted that the measurement of the food demand, real expenditure, sweeteners consumption value, and welfare evaluation are all based on the adjusted value of shipments from the Economic Census report. These wholesale values underestimate the demand and expenditure. In reality, there exists a markup or gross margin between the wholesale and retail value of consumption. The gross margin for the food and beverage stores is estimated by the Bureau of Labor Statistics and Annual Benchmark report for Retail Trade and Food Services of the Census Bureau to be 28.3\% of sales in 2001 (Nakamura, 2008). In aggregate, the wholesale values would need to be rescaled by 1.39 to get the retail value of consumption. The rescaled values of food consumption, real expenditure, sweetener consumption, and EV will reflect the real impacts on consumers.

\section{Limitations and Extensions}

There are obvious limitations in our analysis. First, we only account for the consumption effect of the policy instruments. Long-run health benefits derived from reduced sweetener consumption (e.g., reduced obesity) are not incorporated in the welfare measurement among the policy effects. So we overstate the loss in welfare and the regressive nature of the tax. The poor group with the largest initial added sweetener consumption would have the greatest reduction in consumption and thus would be likely to experience greater health benefits. Second, food items included in the 
investigation are relatively limited. Some caloric-intensive foods are not included (such as food with fat). Smed, Jensen and Denver (2007) found that the reduction in sweetened products was accompanied by increased demand for higher fat foods. Future extension of our research should take into account the substitution between the added sugar and fat component or go to the subfood sectors to capture sector-specific effects.

Third, the composition of food at home and food away from home may be quite different. Food at home might be much healthier than food away from home (Schroeter and Lusk, 2007), which is often highly caloric. By more carefully accounting for expenditure differences in the distribution of different food at home to expenditures on food away from home, our results may change. Data are relatively limited in this regard. Fourth, and finally, this analysis enables evaluation of the effects for different demographic groups but we include only income as the demographic variable in this study. Other demographic variables could be included in future studies to investigate the role of elasticities in the consumption patterns and to examine the changes in welfare. 


\section{References}

Atwood, J.A., and G.A. Helmers. 1998. "Examining Quantity and Quality Effects of Restricting Nitrogen Applications to Feedgrains.” American Journal of Agricultural Economics 80: 369-381.

Beghin, J.C., J. Bureau, and S. Drogué. 2004. "The Calibration of Incomplete Demand Systems in Quantitative Analysis.” Applied Economics 36(8): 839-847.

Beghin, J.C., and H.H. Jensen. 2008. "Farm Policies and Added Sugars in US Diets.” Food Policy 33: 480-488.

Boizot-Szantaï, C., and F. Etilé. 2005. “The Food Prices / Body Mass Index Relationship: Theory and Evidence from a Sample of French Adults.” Paper prepared for presentation at the Congress of the EAAE (European Association of Agricultural Economists), Copenhagen, Denmark, 24-27 August.

Bureau of Labor Statistics. 2002. 2002 Expenditure Tables. U.S. Department of Labor. http://www.bls.gov/cex/csxstnd.htm\#2002 (accessed July 2008)

Cash, S.B., D.L. Sunding, and D. Zilberman. 2005. "Fat Taxes and Thin Subsidies: Prices, Diet, and Health Outcomes." Acta Agriculturae Scand C: Food Economics (special issue on the economics and policy of diet and health) 2: 167-174

Chouinard, H.H., D.E. Davis, J.T. LaFrance, and J.M. Perloff. 2007. "Fat Taxes: Big Money for Small Changes." Forum for Health Economics \& Policy, 10(2), Art.2, available online at http://www.bepress.com/fhep/10/2/2.

—. 2010. "Milk Marketing Order Winners and Losers." Applied Economic Perspectives and Policy 32(1): 59-76.

Farah, H., and J. Buzby. 2005. “U.S. Food Consumption Up 16 Percent Since 1970”. Amber Waves, United States Department of Agriculture, Economic Research Service. http://www.ers.usda.gov/AmberWaves/November05/Findings/USFoodConsumption.htm (accessed January. 2009).

Flegal, K.M., M.D. Carroll, C.L. Ogden, and L.R. Curtin. 2010. "Prevalence and Trends in Obesity among US Adults, 1999-2008.” Journal of the American Medical Association 303(3): 235-241.

Goodwin, B., and G. Brester, 1995. "Structural Change in Factor Demand Relationship in the U.S. Food and Kindred Products Industry.” American Journal of Agricultural Economics. 77: 69-79.

Gustavsen, G. 2005. "Public Policies and the Demand for Carbonated Soft Drinks: A Censored Quartile Regression Approach.” Paper prepared for presentation at the Congress of the EAAE (European Association of Agricultural Economists), Copenhagen, Denmark, 24-27 August.

Kuchler, F., A Tegene, and J.M. Harris. 2004. "Taxing Snack Foods: What to Expect for Diet and Tax Revenues.” Agriculture Information Bulletin No. 747-08, August.

-. 2005. "Taxing Snacks Foods: Manipulating Diet Quality or Financing Information Programs?” Review of Agricultural Economics 27 (1): 4-20

LaFrance, J.T. 1998. “The LINQUAD Incomplete Demand Model.” Working Paper, Department of Agricultural and Resource Economics, University of California, Berkeley.

Leicester, A., and F. Windmeijer. 2004. "The 'Fat Tax' Economic Incentives to Reduce Obesity.” London: The Institute for Fiscal Studies. Briefing Note No. 49. 
Mullen, J.D., M.K. Wohlgenant, and D.E. Farris. 1988. "Input Substitution and the Distribution of Surplus Grains from Lower U.S. Beef-Processing Costs." American Journal of Agricultural Economics 70: 245-254.

Nakamura, E. 2008. "Pass-Through in Retail and Wholesale.” American Economic Review 98(2): 430-437.

O’Donoghue, T., and M. Rabin. 1999. “Doing It Now or Later.” The American Economic Review 89(1): 103-124.

Richards, T.J., P.M. Patterson, and A. Tegene. 2007. "Obesity and Nutrient Consumption: A Rational Addiction?” Contemporary Economic Policy 25(3): 309-324.

Santarossa, J.M., and D.D. Mainland. 2003. "Employing an Environmental Taxation Mechanism to Reduce Fat Intake.” In Chern, W and Rickertsen, K, ed. Health, Nutrition and Food Demand. Oxford : CABI Publishing, pp. 223-245.

Schmidhuber, J. 2004. "The Growing Global Obesity Problem: Some Policy Options to Address It.” Journal of Agricultural and Development Economics 1(2): 272-290.

Schroeter, C., and J. Lusk. 2007. "The Impact of Economic Factors on Consumer Health." Selected paper presented at the WAEA (Western Agricultural Economic Association) Annual Meeting, Portland, Oregon, 29 July-1 August.

Schroeter, C., J. Lusk, and W. Tyner. 2008. "Determining the Impact of Food Price and Income Changes on Body Weight." Journal of Health Economics 27:45-68.

Smed, S., J.D. Jensen, and S. Denver. 2007. "Socio-economic Characteristics and the Effect of Taxation as a Health Policy Instrument." Food Policy 32: 5-6.

Sumner, D.A., and M.K.Wohlgenant. 1985. "Effects of an Increase in the Federal Excise Tax on Cigarettes." American Journal of Agricultural Economics 67(2): 235-242.

U.S. Census Bureau. 2004. Economic Census, Manufacturing Reports, Industry Series, 2002. U.S. Department of Commerce, Census Bureau. www.census.gov/econ/census02/ guide/INDRPT31.HTM (accessed April 2008).

U.S. Department of Health and Human Services and U.S. Department of Agriculture, Economic Research Service. 2005. Dietary Guidelines for Americans, 2005. http://www.health.gov/dietaryguidelines/dga2005/document/ (accessed November 2009).

U.S. Department of Agriculture, Economic Research Service.

—. 2008a. "Commodity and Food Elasticities" http://www.ers.usda.gov/Data/Elasticities/ (accessed August 2008).

— 2008b. "Food Availability Data System". http://www.ers.usda.gov/Data/ FoodConsumption/FoodAvailIndex.htm (accessed September 2008). 
Table 1. Categories of the Sweeteners in the U.S. Food Manufacturing Industry ${ }^{\mathrm{a}}$

\begin{tabular}{|c|c|c|}
\hline $\begin{array}{l}\text { Sweeteners } \\
\text { Group }\end{array}$ & $\begin{array}{c}\text { Material } \\
\text { Code }\end{array}$ & Materials Consumed \\
\hline \multirow{6}{*}{$\begin{array}{l}\text { Sugars } \\
\text { (Sugars } \\
\text { from cane or } \\
\text { beet) }\end{array}$} & 31131001 & Sugar, cane and beet (sugar solids) \\
\hline & 31131005 & Sugar, cane and beet (sugar solids), excluding brown \\
\hline & 31131009 & Brown sugar, cane and beet (sugar solids) \\
\hline & 31131100 & Raw cane sugar (converted to 96\% basis) \\
\hline & 11193000 & Sugar cane \\
\hline & 11199100 & Sugar beets \\
\hline \multirow{7}{*}{$\begin{array}{l}\text { Corn } \\
\text { sweeteners }\end{array}$} & 31122101 & Corn syrup \\
\hline & 31122103 & High fructose corn syrup (HFCS) (solids) \\
\hline & 31122105 & Fructose corn syrup (50\% or less) (solids) \\
\hline & 31122107 & Fructose corn syrup (50\% or more) (solids) \\
\hline & 31122111 & $\begin{array}{l}\text { Glucose syrup (corn syrup), conventional and regular } \\
\text { (solids) }\end{array}$ \\
\hline & 31122117 & Crystalline fructose (dry fructose) \\
\hline & 31122119 & $\begin{array}{l}\text { Dextrose and corn syrup, including corn syrup solids (dry } \\
\text { weight) }\end{array}$ \\
\hline $\begin{array}{l}\text { Other } \\
\text { sweeteners }\end{array}$ & 31100003 & $\begin{array}{l}\text { Other natural sweeteners (including dextrose, honey, } \\
\text { molasses, and blends of corn sweeteners and sugar) } \\
\text { (solids) }\end{array}$ \\
\hline \multirow{2}{*}{$\begin{array}{l}\text { Artificial } \\
\text { sweeteners }\end{array}$} & 32510053 & Sugar substitutes (mannitol, sorbitol, etc.) \\
\hline & 32510057 & Artificial sweeteners (solids) \\
\hline
\end{tabular}

Source: 2002 Economic Census Industry Series Reports (Manufacturing).

a. Material code and material categories are based on Table 7 in the 2002 Economic Census Industry Series Reports (Manufacturing). 
Table 2. Categories of Sweetener-Intensive Intermediate Materials in the U.S. Food Manufacturing Industry ${ }^{a}$

\begin{tabular}{|l|c|l|}
\hline $\begin{array}{l}\text { Selected Intermediate } \\
\text { Products }\end{array}$ & $\begin{array}{c}\text { Representative Industry } \\
\text { NAICS Code }\end{array}$ & $\begin{array}{l}\text { Representative Industry } \\
\text { NAICS Definition }\end{array}$ \\
\hline Fluid milk & 311511 & Fluid milk mfg \\
\hline Cheese & 311513 & Cheese mfg \\
\hline $\begin{array}{l}\text { Dry, condensed and } \\
\text { evaporated milk }\end{array}$ & 311514 & $\begin{array}{l}\text { Dry, condensed, and } \\
\text { evaporated dairy } \\
\text { product mfg }\end{array}$ \\
\hline $\begin{array}{l}\text { Ice cream and yogurt } \\
\text { mixes }\end{array}$ & 311520 & $\begin{array}{l}\text { Ice cream and frozen } \\
\text { dessert mfg }\end{array}$ \\
\hline Prepared mixes & 311822 & $\begin{array}{l}\text { Flour mixes and dough } \\
\text { mfg from purchased flour }\end{array}$ \\
\hline Flour & 311211 & Flour milling \\
\hline Liquid beverage base & 311930 & $\begin{array}{l}\text { Flavoring syrup and } \\
\text { concentrate mfg }\end{array}$ \\
\hline Chocolate & 311320 & $\begin{array}{l}\text { Chocolate and } \\
\text { confectionery mfg from } \\
\text { cacao beans }\end{array}$ \\
\hline
\end{tabular}

Source: 2002 Economic Census Industry Series Reports (Manufacturing).

a. Material code and material categories are based on Table 7 in the 2002 Economic Census Industry Series Reports (Manufacturing). 
Table 3. Nine Target Sweetener-Intensive Foods in the U.S. Food Manufacturing Industry

\begin{tabular}{|c|c|c|c|c|}
\hline $\begin{array}{l}\text { Sweetener- } \\
\text { Intensive Foods }\end{array}$ & $\begin{array}{l}\text { NAICS } \\
\text { Code }\end{array}$ & NAICS Definition & $\begin{array}{l}\text { Proportion of } \\
\text { Products } \\
\text { Going to } \\
\text { Direct } \\
\text { Consumption } \\
(\%) \\
\end{array}$ & $\begin{array}{c}\text { Consumption } \\
\text { Adjustment } \\
\text { Ratio }^{\mathrm{a}}\end{array}$ \\
\hline \multirow{2}{*}{$\begin{array}{l}\text { Milk (Fluid milk / } \\
\text { Dry, condensed, } \\
\text { and evaporated } \\
\text { dairy product) }\end{array}$} & 311511 & Fluid milk mfg & 91.06 & 1.00 \\
\hline & 311514 & $\begin{array}{l}\text { Dry, condensed, and } \\
\text { evaporated dairy product } \\
\text { mfg }\end{array}$ & 86.30 & 0.75 \\
\hline Cheese & 311513 & Cheese mfg & 81.08 & 1.03 \\
\hline Ice cream / yogurt & 311520 & $\begin{array}{l}\text { Ice cream and frozen } \\
\text { dessert mfg }\end{array}$ & 93.86 & 1.00 \\
\hline \multirow{6}{*}{$\begin{array}{l}\text { Breakfast cereal / } \\
\text { Bakery }\end{array}$} & 311211 & Flour milling & 65.06 & 0.75 \\
\hline & 311230 & Breakfast cereal mfg & 100 & 0.75 \\
\hline & 311812 & Commercial bakeries & 100 & 0.75 \\
\hline & 311813 & $\begin{array}{l}\text { Frozen cakes, pies, and } \\
\text { other pastries mfg }\end{array}$ & 100 & 0.75 \\
\hline & 311821 & Cookie and cracker mfg & 100 & 0.75 \\
\hline & 311822 & $\begin{array}{l}\text { Flour mixes and dough } \\
\text { mfg from purchased flour }\end{array}$ & 91.94 & 0.75 \\
\hline \multirow[b]{2}{*}{ Soft drink } & 312111 & Soft drink mfg & 100 & 1.00 \\
\hline & 311930 & $\begin{array}{l}\text { Flavoring syrup and } \\
\text { concentrate mfg }\end{array}$ & 16.42 & 1.00 \\
\hline \multirow{2}{*}{ Juice } & $311411^{b}$ & $\begin{array}{l}\text { Frozen fruit, juice and } \\
\text { vegetable mfg }\end{array}$ & 100 & 1.78 \\
\hline & $311421^{\mathrm{c}}$ & $\begin{array}{l}\text { Fruit and vegetable } \\
\text { canning }\end{array}$ & 100 & 1.52 \\
\hline \multirow{6}{*}{$\begin{array}{l}\text { Sweetener } \\
\text { products (Refined } \\
\text { sugar / } \\
\text { Confectionery / } \\
\text { Honey, Molasses, } \\
\text { Syrup and Gelatin } \\
\text { pudding mix / } \\
\text { Jam and jelly) }\end{array}$} & $\begin{array}{c}311312 / \\
311313 \\
\end{array}$ & $\begin{array}{l}\text { Cane sugar refining / Beet } \\
\text { sugar manufacturing }\end{array}$ & 58.02 & 1.02 \\
\hline & 311320 & $\begin{array}{l}\text { Chocolate and } \\
\text { confectionery mfg from } \\
\text { cacao beans }\end{array}$ & 64.44 & 1.07 \\
\hline & 311330 & $\begin{array}{l}\text { Confectionery mfg from } \\
\text { purchased chocolate }\end{array}$ & 100 & 1.07 \\
\hline & 311340 & $\begin{array}{l}\text { Non-chocolate } \\
\text { confectionery mfg }\end{array}$ & 100 & 1.07 \\
\hline & $311999^{d}$ & $\begin{array}{l}\text { All other miscellaneous } \\
\text { food mfg }\end{array}$ & 100 & 0.72 \\
\hline & $311421^{\mathrm{e}}$ & $\begin{array}{l}\text { Fruit and vegetable } \\
\text { canning }\end{array}$ & 100 & 1.52 \\
\hline $\begin{array}{l}\text { Processed fruits } \\
\text { and vegetables }\end{array}$ & $311423^{f}$ & $\begin{array}{l}\text { Dried and dehydrated } \\
\text { food mfg }\end{array}$ & 100 & 0.63 \\
\hline
\end{tabular}




\begin{tabular}{|c|c|c|c|c|}
\hline $\begin{array}{l}\text { (Dried fruits and } \\
\text { vegetables / } \\
\text { Tomato } \\
\text { sauce/Catsup) }\end{array}$ & $311421^{\mathrm{g}}$ & $\begin{array}{l}\text { Fruit and vegetable } \\
\text { canning }\end{array}$ & 100 & 1.52 \\
\hline \multirow{2}{*}{$\begin{array}{l}\text { Condiments / } \\
\text { Spices } \\
\text { (Mayonnaise, } \\
\text { dressing, and } \\
\text { other prepared } \\
\text { sauce+ Spice and } \\
\text { extract) }\end{array}$} & 311941 & $\begin{array}{l}\text { Mayonnaise, dressing, and } \\
\text { other prepared sauce mfg }\end{array}$ & 100 & 1.00 \\
\hline & 311942 & Spice and extract mfg & 100 & 4.28 \\
\hline
\end{tabular}

Source: 2002 Economic Census Industry Series Reports (Manufacturing).

a. Consumption adjustment ratios (the ratio of food disappearance to food production) are based on USDA/ERS Food Availability Data System.

b. "Juice” was matched to segment of "Frozen juices, aides, drink, and cocktail” of food manufacturing industry 311411.

c. "Juice" was matched to segment of "Canned fruit juices, nectars, and concentrates + Fresh fruit juices and nectars" of food manufacturing industry 311421.

d. "Sweetener products: All other miscellaneous food mfg" was matched to segment of "Desserts (readyto-mix) + Sweetening syrup and molasses” of food manufacturing industry 311999.

e. "Sweetener products: Fruit and vegetable canning" was matched to segment of "Canned jams, jellies and preserves" of food manufacturing industry 311421.

f. "Processed fruits and vegetables: Dried and dehydrated food mfg" was matched to segment of "Dried and dehydrated fruits and vegetables, including freeze-dried" of food manufacturing industry 311423.

g. "Processed fruits and vegetables: Fruit and vegetable canning" was matched to segment of "Canned catsup and other tomato based sauce" of food manufacturing industry 311421. 
Table 4. Values and Shares of Sweeteners in Nine Target Sweetener-Intensive U.S. Food Manufacturing Industry

\begin{tabular}{|c|c|c|c|c|c|}
\hline \multirow{2}{*}{$\begin{array}{l}\text { Sweetener- } \\
\text { Intensive } \\
\text { Food }\end{array}$} & \multicolumn{5}{|c|}{ Values of Sweeteners (million dollars) and Industry Value Shares } \\
\hline & Sugars & $\begin{array}{c}\text { Corn } \\
\text { Sweeteners }\end{array}$ & $\begin{array}{c}\text { Other } \\
\text { Sweeteners }\end{array}$ & $\begin{array}{c}\text { Artificial } \\
\text { Sweeteners }\end{array}$ & $\begin{array}{c}\text { All } \\
\text { Sweeteners }\end{array}$ \\
\hline Milk & $\begin{array}{c}145566.23 \\
(3.76 \%)\end{array}$ & $\begin{array}{c}204832.69 \\
(10.00 \%)\end{array}$ & $\begin{array}{c}0.00 \\
(0.00 \%)\end{array}$ & $\begin{array}{c}111.54 \\
(0.07 \%)\end{array}$ & $\begin{array}{c}350510.45 \\
(5.52 \%)\end{array}$ \\
\hline Cheese & $\begin{array}{l}7005.03 \\
(0.18 \%)\end{array}$ & $\begin{array}{c}14767.97 \\
(0.72 \%)\end{array}$ & $\begin{array}{c}0.00 \\
(0.00 \%)\end{array}$ & $\begin{array}{c}0.00 \\
(0.00 \%)\end{array}$ & $\begin{array}{c}21773.00 \\
(0.34 \%)\end{array}$ \\
\hline $\begin{array}{l}\text { Ice cream / } \\
\text { yogurt }\end{array}$ & $\begin{array}{c}88003.26 \\
(2.28 \%)\end{array}$ & $\begin{array}{l}78183.66 \\
(3.82 \%)\end{array}$ & $\begin{array}{c}0.00 \\
(0.00 \%)\end{array}$ & $\begin{array}{c}162.28 \\
(0.10 \%)\end{array}$ & $\begin{array}{c}166349.20 \\
(2.62 \%)\end{array}$ \\
\hline $\begin{array}{l}\text { Breakfast } \\
\text { cereal / } \\
\text { Bakery } \\
\end{array}$ & $\begin{array}{c}792602.14 \\
(20.49 \%)\end{array}$ & $\begin{array}{c}171137.66 \\
(8.35 \%)\end{array}$ & $\begin{array}{c}118477.75 \\
(44.93 \%)\end{array}$ & $\begin{array}{c}13367.47 \\
(7.88 \%)\end{array}$ & $\begin{array}{c}1095585.03 \\
(17.25 \%)\end{array}$ \\
\hline Soft drink & $\begin{array}{c}58065.00 \\
(1.50 \%)\end{array}$ & $\begin{array}{c}1113977.00 \\
(54.36 \%)\end{array}$ & $\begin{array}{l}42982.00 \\
(16.30 \%)\end{array}$ & $\begin{array}{l}33746.00 \\
(19.89 \%)\end{array}$ & $\begin{array}{c}1248770.00 \\
(19.67 \%)\end{array}$ \\
\hline Juice & $\begin{array}{c}26169.29 \\
(0.68 \%)\end{array}$ & $\begin{array}{c}86191.00 \\
(4.21 \%)\end{array}$ & $\begin{array}{c}0.00 \\
(0.00 \%) \\
\end{array}$ & $\begin{array}{c}0.00 \\
(0.00 \%) \\
\end{array}$ & $\begin{array}{c}112360.30 \\
(1.77 \%)\end{array}$ \\
\hline $\begin{array}{l}\text { Sweetener } \\
\text { products }\end{array}$ & $\begin{array}{c}2649603.07 \\
(68.51 \%)\end{array}$ & $\begin{array}{c}255077.12 \\
(12.45 \%)\end{array}$ & $\begin{array}{c}19092.95 \\
(7.24 \%)\end{array}$ & $\begin{array}{c}112985.72 \\
(66.61 \%)\end{array}$ & $\begin{array}{c}3036758.86 \\
(47.82 \%)\end{array}$ \\
\hline $\begin{array}{l}\text { Processed } \\
\text { fruits and } \\
\text { vegetables }\end{array}$ & $\begin{array}{c}18492.67 \\
(0.48 \%)\end{array}$ & $\begin{array}{c}65166.89 \\
(3.18 \%)\end{array}$ & $\begin{array}{c}0.00 \\
(0.00 \%)\end{array}$ & $\begin{array}{c}0.00 \\
(0.00 \%)\end{array}$ & $\begin{array}{c}83659.56 \\
(1.32 \%)\end{array}$ \\
\hline $\begin{array}{l}\text { Condiments / } \\
\text { Spices }\end{array}$ & $\begin{array}{c}81829.56 \\
(2.12 \%)\end{array}$ & $\begin{array}{c}59831.74 \\
(2.92 \%)\end{array}$ & $\begin{array}{l}83132.41 \\
(31.53 \%)\end{array}$ & $\begin{array}{l}9255.16 \\
(5.46 \%)\end{array}$ & $\begin{array}{c}234048.88 \\
(3.69 \%)\end{array}$ \\
\hline $\begin{array}{l}\text { Sum of Nine } \\
\text { Target } \\
\text { Sweetener- } \\
\text { Intensive } \\
\text { Foods }\end{array}$ & $\begin{array}{c}17350095.40 \\
(100.00 \%)\end{array}$ & $\begin{array}{c}15361062.51 \\
(100.00 \%)\end{array}$ & $\begin{array}{l}800258.30 \\
(100.00 \%)\end{array}$ & $\begin{array}{l}151399.65 \\
(100.00 \%)\end{array}$ & $\begin{array}{c}29622485.68 \\
(100.00 \%)\end{array}$ \\
\hline
\end{tabular}

Source: 2002 Economic Census Industry Series Reports (Manufacturing).

Note: Numbers in parentheses are the (value) shares of the respective sweetener used in the nine target sweetener-intensive foods. 
Table 5. Cost Shares of Sweeteners in Nine Target Sweetener-Intensive U.S. Food Manufacturing Industry

\begin{tabular}{|l|c|c|c|c|c|}
\hline \multirow{2}{*}{ Food } & \multicolumn{5}{|c|}{ Cost Shares of Sweeteners (\%) } \\
\cline { 2 - 6 } & Sugars & $\begin{array}{c}\text { Corn } \\
\text { Sweeteners }\end{array}$ & $\begin{array}{c}\text { Other } \\
\text { Sweeteners }\end{array}$ & $\begin{array}{c}\text { Artificial } \\
\text { Sweeteners }\end{array}$ & $\begin{array}{c}\text { All } \\
\text { Sweeteners }\end{array}$ \\
\hline Milk & 0.5171 & 0.7276 & 0.0000 & 0.0004 & 1.2451 \\
\hline Cheese & 0.0381 & 0.0804 & 0.0000 & 0.0000 & 0.1185 \\
\hline Ice cream / yogurt & 1.1464 & 1.0185 & 0.0000 & 0.0021 & 2.1670 \\
\hline $\begin{array}{l}\text { Breakfast cereal / } \\
\text { Bakery }\end{array}$ & 1.8881 & 0.4077 & 0.2822 & 0.0318 & 2.6098 \\
\hline Soft drink & 0.1750 & 3.3567 & 0.1295 & 0.1017 & 3.7628 \\
\hline Juice & 0.2174 & 0.7159 & 0.0000 & 0.0000 & 0.9333 \\
\hline Sweetener products & 10.7965 & 1.0394 & 0.0778 & 0.4604 & 12.3740 \\
\hline $\begin{array}{l}\text { Processed fruits } \\
\text { and vegetables }\end{array}$ & 0.2245 & 0.7912 & 0.0000 & 0.0000 & 1.0157 \\
\hline $\begin{array}{l}\text { Condiments / } \\
\text { Spices }\end{array}$ & 0.2790 & 0.2040 & 0.2834 & 0.0316 & 0.7980 \\
\hline
\end{tabular}

Source: Calculated from 2002 Economic Census Industry Series Reports (Manufacturing). 
Table 6. Own-Price and Income / Total Expenditure Elasticities of Nine Target Sweetener-Intensive Foods

\begin{tabular}{|c|c|c|c|c|c|c|c|c|}
\hline \multirow{2}{*}{ Food } & \multicolumn{8}{|c|}{ Elasticities } \\
\hline & \multicolumn{4}{|c|}{ Own-Price Elasticity } & \multicolumn{4}{|c|}{ Income / Total Expenditure Elasticity } \\
\hline Cheese & -1.07 & 0.62 & -1.90 & -0.33 & 0.22 & 0.75 & -0.42 & 1.40 \\
\hline Ice cream / yogurt & -0.83 & 0.07 & -0.91 & -0.74 & -0.17 & 0.22 & -0.41 & 0.04 \\
\hline Breakfast cereal / Bakery & -0.47 & 0.29 & -1.03 & -0.04 & 0.23 & 0.49 & -0.55 & 1.18 \\
\hline Sweetener products & -0.50 & 0.72 & -2.63 & -0.05 & 0.05 & 0.40 & -0.71 & 0.19 \\
\hline Processed fruits and vegetables & -1.97 & 0.90 & -3.07 & -0.64 & 0.49 & 0.56 & -0.30 & 1.16 \\
\hline Condiments / Spices & -1.04 & 0.49 & -1.93 & -0.58 & 0.12 & 0.42 & 0.05 & 1.00 \\
\hline
\end{tabular}

Source: USDA/ERS Commodity and Food Elasticities, 2008a; Chouinard et al., 2010. 
Table 7. Cross-Price Elasticities of Nine Target Sweetener-Intensive Foods

\begin{tabular}{|c|c|c|c|c|c|c|c|c|c|}
\hline Food & Milk & Cheese & $\begin{array}{l}\text { Ice cream } \\
\text { / yogurt }\end{array}$ & $\begin{array}{c}\text { Breakfast } \\
\text { cereal / } \\
\text { Bakery } \\
\end{array}$ & $\begin{array}{c}\text { Soft } \\
\text { drink }\end{array}$ & Juice & $\begin{array}{c}\text { Sweetener } \\
\text { products }\end{array}$ & $\begin{array}{l}\text { Processed } \\
\text { fruits and } \\
\text { vegetables }\end{array}$ & $\begin{array}{c}\text { Condiments } \\
\text { / Spices }\end{array}$ \\
\hline Milk & & -0.0267 & & -0.0281 & -0.0709 & 0.0171 & 0.0055 & -0.0137 & \\
\hline Cheese & & & -0.0485 & -0.0386 & & -0.0155 & 0.0364 & 0.0172 & \\
\hline Ice cream / yogurt & & & & -0.0349 & & -0.0047 & & & \\
\hline $\begin{array}{l}\text { Breakfast cereal / } \\
\text { Bakery }\end{array}$ & & & & & & 0.0055 & 0.0203 & 0.0205 & \\
\hline Soft drink & & & & & & -0.0030 & & & \\
\hline Juice & & & & & & & 0.0482 & 0.0180 & \\
\hline $\begin{array}{l}\text { Sweetener } \\
\text { products }\end{array}$ & & & & & & & & 0.0050 & \\
\hline $\begin{array}{l}\text { Processed fruits } \\
\text { and vegetables }\end{array}$ & & & & & & & & & \\
\hline $\begin{array}{l}\text { Condiments / } \\
\text { Spices }\end{array}$ & & & & & & & & & \\
\hline
\end{tabular}

Source: USDA/ERS Commodity and Food Elasticities, 2008a; Chouinard et al., 2010. 
Table 8. Per Capita Income and Food Expenditure Distribution among Nine Sweetener-Intensive Foods (Dollars)

\begin{tabular}{|c|c|c|c|c|c|c|}
\hline & & \multicolumn{5}{|c|}{ Quintiles of Income } \\
\hline & $\begin{array}{c}\text { All } \\
\text { Households }\end{array}$ & $\begin{array}{c}\text { Lowest } \\
20 \%\end{array}$ & $\begin{array}{c}\text { Second } \\
20 \%\end{array}$ & $\begin{array}{l}\text { Third } \\
20 \%\end{array}$ & $\begin{array}{c}\text { Fourth } \\
20 \%\end{array}$ & $\begin{array}{c}\text { Highest } \\
20 \%\end{array}$ \\
\hline Population (billion) & 0.28 & 0.04 & 0.05 & 0.06 & 0.06 & 0.07 \\
\hline Average annual income after taxes & 18773.60 & 4857.46 & 9406.96 & 14214.37 & 20019.16 & 35049.03 \\
\hline Annual food expenditure (per capita) & 726.13 & 702.63 & 679.00 & 691.40 & 731.25 & 793.57 \\
\hline Milk & 100.44 & 104.98 & 107.31 & 95.18 & 99.59 & 98.18 \\
\hline Cheese & 65.55 & 60.44 & 56.54 & 62.73 & 66.77 & 75.57 \\
\hline Ice cream / yogurt & 27.39 & 25.26 & 23.62 & 26.21 & 27.90 & 31.58 \\
\hline Breakfast cereal / Bakery & 149.78 & 150.03 & 141.06 & 138.98 & 148.90 & 164.84 \\
\hline Soft drink & 118.41 & 114.12 & 109.23 & 112.87 & 120.07 & 129.86 \\
\hline Juice & 42.96 & 41.98 & 40.55 & 40.33 & 42.70 & 47.40 \\
\hline Sweetener products & 87.56 & 86.58 & 79.50 & 85.20 & 87.20 & 95.78 \\
\hline Processed fruits and vegetables & 29.39 & 28.84 & 27.74 & 28.36 & 29.48 & 31.53 \\
\hline Condiments / Spices & 104.65 & 90.40 & 93.45 & 101.54 & 108.64 & 118.83 \\
\hline \multicolumn{7}{|l|}{ Sweeteners } \\
\hline $\begin{array}{l}\text { All Sweeteners (sugar equivalent) } \\
\text { (pounds) }\end{array}$ & 105.69 & 103.83 & 97.85 & 101.28 & 105.85 & 115.37 \\
\hline Sugars & 61.90 & 61.21 & 56.96 & 59.54 & 61.73 & 67.67 \\
\hline Corn Sweeteners & 54.81 & 53.41 & 51.24 & 52.26 & 55.22 & 59.63 \\
\hline Other Sweeteners & 2.86 & 2.72 & 2.63 & 2.71 & 2.89 & 3.17 \\
\hline Artificial Sweeteners & 0.54 & 0.53 & 0.49 & 0.52 & 0.54 & 0.59 \\
\hline
\end{tabular}

Source: Consumer Expenditure Survey (CEX) 2002, BLS; 2002 Economic Census Industry Series Reports (Manufacturing).

a. Industry-level value of shipment in 2002 Economic Census Industry Series Reports (Manufacturing) are distributed to income groups by the athome food expenditure weight from CEX 2002. The weight for "Fluid milk / Dry, condensed, and evaporated dairy product" is from "Fresh milk and cream"; weights for "Cheese" and "Ice cream yogurt" are from "Other dairy products"; weight for "Breakfast cereal/Bakery" is from "Cereals and bakery products"; weight for "Soft drink" is from "Nonalcoholic beverages"; weight for "Juice” is from "Processed fruits"; weight for "Refined Sugar + Confectionery + Honey, Molasses, Syrup and Gelatin pudding mix + Jam and jelly" is from "Sugars and other sweets"; weight for "Dried fruit and vegetables + Tomato Sauce/Catsup" is from "Processed fruits and processed vegetables"; weight for "Mayonnaise, dressing, and other prepared sauce + Spice and extract” is from "Miscellaneous foods.” 
Table 9. Marshallian Elasticities of Nine Target Sweetener-Intensive Foods for All Households

\begin{tabular}{|l|c|c|c|c|c|c|c|c|c|}
\hline Food & Milk & Cheese & $\begin{array}{c}\text { Ice } \\
\text { cream / } \\
\text { yogurt }\end{array}$ & $\begin{array}{c}\text { Breakfast } \\
\text { cereal / } \\
\text { Bakery }\end{array}$ & $\begin{array}{c}\text { Soft } \\
\text { drink }\end{array}$ & Juice & $\begin{array}{c}\text { Sweetener } \\
\text { products }\end{array}$ & $\begin{array}{c}\text { Processed } \\
\text { fruits and } \\
\text { vegetables }\end{array}$ & $\begin{array}{c}\text { Condiments / } \\
\text { Spices }\end{array}$ \\
\hline Milk & -0.72467 & -0.02670 & -0.00005 & -0.02812 & -0.07089 & 0.01710 & 0.00544 & -0.01371 & -0.00014 \\
\hline Cheese & -0.04194 & -1.06820 & -0.04846 & -0.03849 & -0.00144 & -0.01555 & 0.03630 & 0.01715 & -0.00109 \\
\hline $\begin{array}{l}\text { Ice cream / } \\
\text { yogurt }\end{array}$ & 0.00090 & -0.11461 & -0.83342 & -0.03491 & 0.00112 & -0.00469 & 0.00077 & 0.00015 & 0.00085 \\
\hline $\begin{array}{l}\text { Breakfast } \\
\text { cereal / } \\
\text { Bakery }\end{array}$ & -0.01991 & -0.01686 & -0.00696 & -0.47447 & -0.00147 & 0.00544 & 0.02015 & 0.02040 \\
\hline Soft drink & -0.05981 & 0.00009 & 0.00005 & 0.00020 & -0.92680 & -0.00300 & 0.00014 & -0.00111 \\
\hline Juice & 0.03811 & -0.02427 & -0.00380 & 0.01773 & -0.01085 & -0.85255 & 0.04798 & 0.01792 & -0.00187 \\
\hline $\begin{array}{l}\text { Sweetener } \\
\text { products }\end{array}$ & 0.00613 & 0.02778 & -0.00008 & 0.03589 & -0.00031 & 0.02430 & -0.50441 & 0.00499 & -0.00024 \\
\hline $\begin{array}{l}\text { Processed } \\
\text { fruits and } \\
\text { vegetables }\end{array}$ & -0.04929 & 0.03734 & -0.00082 & 0.10191 & -0.00315 & 0.02595 & 0.01283 & -1.97171 \\
\hline $\begin{array}{l}\text { Condiments / } \\
\text { Spices }\end{array}$ & -0.00063 & -0.00033 & -0.00021 & -0.00076 & -0.00079 & -0.00018 & -0.00054 & -0.00010 & -1.03918 \\
\hline
\end{tabular}

Source: Elasticities for final products used for the calculation are from USDA/ERS, 2008a and Chouinard et al., 2010. (See Table 6 and 7). 
Table 10. Changes for All Households with Tax on the Price of Final Products for Nine Sweetener-Intensive Foods

\begin{tabular}{|c|c|c|c|c|}
\hline Food & $\begin{array}{c}\text { Initial per } \\
\text { Capita Food } \\
\text { Demand } \\
\text { (dollars) }^{\mathrm{a}}\end{array}$ & $\begin{array}{c}\text { Tax Rate } \\
\text { (\%) }\end{array}$ & $\begin{array}{l}\text { Price with } \\
\text { Tax }\end{array}$ & $\begin{array}{c}\text { Food } \\
\text { Demand } \\
\text { Change (\%) }\end{array}$ \\
\hline Milk & 100.44 & 0.000 & 1.000 & 0.214 \\
\hline Cheese & 65.55 & 0.000 & 1.000 & 1.431 \\
\hline Ice cream / yogurt & 27.39 & 0.000 & 1.000 & 0.027 \\
\hline $\begin{array}{l}\text { Breakfast cereal / } \\
\text { Bakery }\end{array}$ & 149.78 & 0.000 & 1.000 & 0.796 \\
\hline Soft drink & 118.41 & 0.000 & 1.000 & 0.005 \\
\hline Juice & 42.96 & 0.000 & 1.000 & 1.893 \\
\hline Sweetener products & 87.56 & 39.295 & 1.393 & -19.820 \\
\hline $\begin{array}{l}\text { Processed fruits and } \\
\text { vegetables }\end{array}$ & 29.39 & 0.007 & 1.000 & 0.498 \\
\hline Condiments / Spices & 104.65 & 0.000 & 1.000 & -0.019 \\
\hline Sweeteners & $\begin{array}{r}\text { Initial p } \\
\text { Sweeteners } \\
\text { (l }\end{array}$ & $\begin{array}{l}\text { Capita } \\
\text { nsumption }\end{array}$ & $\begin{array}{r}\text { Sweeteners } \\
\text { Quanti }\end{array}$ & $\begin{array}{l}\text { onsumption } \\
\text { Change } \\
\text { ) }\end{array}$ \\
\hline $\begin{array}{l}\text { All Sweeteners } \\
\text { (sugar equivalent) }\end{array}$ & 10 & & & 000 \\
\hline Sugars & & & & \\
\hline Corn Sweeteners & & & & \\
\hline Other Sweeteners & & & & \\
\hline Artificial Sweeteners & & & & 139 \\
\hline $\begin{array}{l}\text { Real Expenditure on } \\
\text { Nine Foods } \\
\end{array}$ & $\begin{array}{c}\text { Initial per } \\
\text { Expenditu }\end{array}$ & $\begin{array}{l}\text { pita Real } \\
\text { (dollars) }\end{array}$ & Real Expen & ture Change \\
\hline & & & & \\
\hline Welfare & \multicolumn{4}{|c|}{ Market Welfare Change } \\
\hline EV (million dollars) & \multicolumn{4}{|c|}{-8688.339} \\
\hline Per capita EV (dollars) & \multicolumn{4}{|c|}{-31.000} \\
\hline EV/Income (\%) & \multicolumn{4}{|c|}{0.165} \\
\hline
\end{tabular}

a. Initial prices are normalized to $\$ 1 /$ unit.

b. The quantity of total sweeteners in converted into sugar equivalent based on the sweeteners' caloric content. Cane sugars and beet sugars are relatively pure sucrose. They have approximately $4 \mathrm{kcal}$ per gram. HFCS is the primary corn sweetener in the United States. It has approximately $3 \mathrm{kcal}$ per gram. As a representative of Other Sweeteners, honey has approximately $3 \mathrm{kcal}$ per gram. Aspartame is the most popular artificial sweetener currently used in the U.S. food industry. It has approximately 4 kcal per gram. 
Table 11. Sweeteners Consumption Quantity Changes on All Households and Disaggregated Income Groups for Nine Sweetener-Intensive Foods

\begin{tabular}{|c|c|c|c|c|c|c|}
\hline & \multirow{2}{*}{$\begin{array}{c}\text { All } \\
\text { Households }\end{array}$} & \multicolumn{5}{|c|}{ Households by Quintiles } \\
\hline & & $\begin{array}{c}\text { Lowest } \\
20 \% \\
\end{array}$ & $\begin{array}{c}\text { Second } \\
20 \% \\
\end{array}$ & $\begin{array}{l}\text { Third } \\
20 \% \\
\end{array}$ & $\begin{array}{c}\text { Fourth } \\
20 \% \\
\end{array}$ & $\begin{array}{c}\text { Highest } \\
20 \% \\
\end{array}$ \\
\hline Tax on Price of Final Products & \multicolumn{6}{|c|}{ (Sweeteners consumption quantity change-\%) } \\
\hline All Sweeteners (sugar equivalent) ${ }^{\mathrm{a}}$ & -10.000 & -13.102 & -10.734 & -9.128 & -7.794 & -6.256 \\
\hline Sugars & -13.390 & -19.775 & -16.408 & -13.816 & -11.892 & -9.488 \\
\hline Corn Sweeteners & -2.270 & -3.400 & -2.737 & -2.363 & -1.996 & -1.618 \\
\hline Other Sweeteners & -1.083 & -1.652 & -1.321 & -1.132 & -0.950 & -0.761 \\
\hline Artificial Sweeteners & -13.139 & -19.621 & -16.232 & -13.507 & -11.615 & -9.274 \\
\hline Tax on the Price of Caloric Sweeteners & \multicolumn{6}{|c|}{ (Sweetener consumption quantity change-\%) } \\
\hline All Sweeteners (sugar equivalent) ${ }^{\mathrm{a}}$ & -10.000 & -10.451 & -10.193 & -10.039 & -9.899 & -9.727 \\
\hline Sugars & -8.954 & -9.460 & -9.141 & -9.006 & -8.829 & -8.668 \\
\hline Corn Sweeteners & -12.412 & -12.798 & -12.580 & -12.443 & -12.331 & -12.174 \\
\hline Other Sweeteners & 3.221 & 3.066 & 3.122 & 3.210 & 3.257 & 3.326 \\
\hline Artificial Sweeteners & 1.322 & 0.682 & 1.057 & 1.241 & 1.482 & 1.703 \\
\hline Tax on the Price of Sugars & \multicolumn{6}{|c|}{ (Sweetener consumption quantity change-\%) } \\
\hline All Sweeteners (sugar equivalent) ${ }^{\mathrm{a}}$ & -10.000 & -10.613 & -10.132 & -10.098 & -9.821 & -9.707 \\
\hline Sugars & -22.089 & -22.804 & -22.426 & -22.139 & -21.921 & -21.652 \\
\hline Corn Sweeteners & 7.405 & 7.207 & 7.302 & 7.389 & 7.418 & 7.559 \\
\hline Other Sweeteners & 2.809 & 2.709 & 2.719 & 2.798 & 2.816 & 2.906 \\
\hline Artificial Sweeteners & 0.203 & -0.676 & -0.193 & 0.109 & 0.407 & 0.745 \\
\hline Tax on the Price of Corn Sweeteners & \multicolumn{6}{|c|}{ (Sweetener consumption quantity change-\%) } \\
\hline All Sweeteners (sugar equivalent) ${ }^{\mathrm{a}}$ & -10.000 & -10.273 & -10.250 & -9.979 & -9.993 & -9.744 \\
\hline Sugars & 7.727 & 7.428 & 7.767 & 7.645 & 7.821 & 7.830 \\
\hline Corn Sweeteners & -37.636 & -38.236 & -37.884 & -37.686 & -37.491 & -37.290 \\
\hline Other Sweeteners & 4.729 & 4.394 & 4.564 & 4.710 & 4.829 & 4.909 \\
\hline Artificial Sweeteners & 3.117 & 2.554 & 2.923 & 3.028 & 3.280 & 3.426 \\
\hline
\end{tabular}

a. See Table 10 footnote b. 
Table 12. Real Expenditure Changes and Welfare Loss on All Households and Disaggregated Income Groups for Nine Sweetener-Intensive Foods

\begin{tabular}{|c|c|c|c|c|c|c|}
\hline & \multirow[b]{2}{*}{$\begin{array}{l}\text { All } \\
\text { Households }\end{array}$} & \multicolumn{5}{|c|}{ Households by Quintiles } \\
\hline & & $\begin{array}{c}\text { Lowest } \\
20 \%\end{array}$ & $\begin{array}{c}\text { Second } \\
20 \%\end{array}$ & $\begin{array}{c}\text { Third } \\
20 \%\end{array}$ & $\begin{array}{c}\text { Fourth } \\
20 \%\end{array}$ & $\begin{array}{c}\text { Highest } \\
20 \%\end{array}$ \\
\hline \multicolumn{7}{|c|}{\begin{tabular}{|l} 
Tax on the price of Final Products \\
\end{tabular}} \\
\hline Real expenditure change (\%) & 1.864 & 0.512 & 1.139 & 1.846 & 2.156 & 2.701 \\
\hline \multicolumn{7}{|l|}{ Market welfare change } \\
\hline EV (million dollars) & -8688.339 & -1114.503 & -1361.776 & -1700.009 & -1978.280 & -2533.770 \\
\hline Per capita EV (dollars) & -31.000 & -29.044 & -27.396 & -30.096 & -31.248 & -34.999 \\
\hline EV/Income (\%) & 0.165 & 0.598 & 0.291 & 0.212 & 0.156 & 0.100 \\
\hline \multicolumn{7}{|c|}{ Tax on the price of Caloric Sweeteners } \\
\hline Real expenditure change (\%) & 0.275 & 0.007 & 0.154 & 0.257 & 0.337 & 0.434 \\
\hline \multicolumn{7}{|l|}{ Market welfare change } \\
\hline EV (million dollars) & -1676.896 & -225.009 & -275.217 & -323.774 & -379.645 & -473.252 \\
\hline Per capita EV (dollars) & -5.983 & -5.864 & -5.537 & -5.732 & -5.997 & -6.537 \\
\hline EV/Income (\%) & 0.032 & 0.121 & 0.059 & 0.040 & 0.030 & 0.019 \\
\hline \multicolumn{7}{|l|}{ Tax on the price of Sugars } \\
\hline Real expenditure change (\%) & 0.461 & 0.246 & 0.351 & 0.451 & 0.507 & 0.596 \\
\hline \multicolumn{7}{|l|}{ Market welfare change } \\
\hline EV (million dollars) & -1864.867 & -251.309 & -303.591 & -361.428 & -420.462 & -528.077 \\
\hline Per capita EV (dollars) & -6.654 & -6.549 & -6.108 & -6.399 & -6.641 & -7.294 \\
\hline EV/Income (\%) & 0.035 & 0.135 & 0.065 & 0.045 & 0.033 & 0.021 \\
\hline \multicolumn{7}{|c|}{ Tax on the price of Corn Sweeteners } \\
\hline Real expenditure change (\%) & 0.094 & -0.339 & -0.084 & 0.058 & 0.198 & 0.341 \\
\hline \multicolumn{7}{|l|}{ Market welfare change } \\
\hline EV (million dollars) & -1934.313 & -256.827 & -320.043 & -371.551 & -440.768 & -545.124 \\
\hline Per capita EV (dollars) & -6.902 & -6.693 & -6.439 & -6.578 & -6.962 & -7.530 \\
\hline EV/Income (\%) & 0.037 & 0.138 & 0.068 & 0.046 & 0.035 & 0.021 \\
\hline
\end{tabular}


Table 13. Changes for All Households with Tax on the Price of Caloric Sweeteners for Nine Sweetener-Intensive Foods

\begin{tabular}{|c|c|c|c|c|c|c|c|c|}
\hline \multirow{5}{*}{ Food } & \multirow{5}{*}{$\begin{array}{l}\text { Initial per } \\
\text { Capita Food } \\
\text { Demand } \\
\text { (dollars) }^{\mathbf{a}}\end{array}$} & \multirow{5}{*}{$\begin{array}{c}\text { Price with } \\
\text { Tax }\end{array}$} & \multirow{5}{*}{$\begin{array}{c}\text { Food } \\
\text { Demand } \\
\text { Change } \\
(\%)\end{array}$} & \multicolumn{5}{|c|}{ Tax Rate } \\
\hline & & & & Sugars & $\begin{array}{c}\text { Corn } \\
\text { Sweeteners }\end{array}$ & $\begin{array}{c}\text { Other } \\
\text { Sweeteners }\end{array}$ & & \\
\hline & & & & $27.469 \%$ & $42.946 \%$ & $0.00001 \%$ & & \\
\hline & & & & \multicolumn{5}{|c|}{ Sweeteners Consumption Quantity Change (\%) } \\
\hline & & & & Sugars & $\begin{array}{c}\text { Corn } \\
\text { Sweeteners }\end{array}$ & $\begin{array}{c}\text { Other } \\
\text { Sweeteners }\end{array}$ & $\begin{array}{c}\text { Artificial } \\
\text { Sweeteners }\end{array}$ & $\begin{array}{c}\text { All } \\
\text { Sweeteners } \\
\text { (sugar } \\
\text { equivalent) }\end{array}$ \\
\hline Milk & 100.44 & 1.004 & -0.369 & -1.267 & -11.592 & 1.980 & 14.198 & -7.439 \\
\hline Cheese & 65.55 & 1.000 & -0.002 & -0.928 & -12.802 & 1.062 & 0.310 & -8.971 \\
\hline Ice cream / yogurt & 27.39 & 1.006 & -0.560 & -1.481 & -9.077 & 2.461 & 12.288 & -5.264 \\
\hline $\begin{array}{l}\text { Breakfast cereal / } \\
\text { Bakery }\end{array}$ & 149.78 & 1.006 & -0.232 & -7.921 & -5.904 & 1.984 & 9.754 & -6.653 \\
\hline Soft drink & 118.41 & 1.013 & -1.182 & -2.097 & -16.439 & 8.762 & 5.041 & -14.197 \\
\hline Juice & 42.96 & 1.003 & -0.103 & -1.089 & -14.018 & 5.626 & 1.505 & -10.740 \\
\hline $\begin{array}{l}\text { Sweetener } \\
\text { products }\end{array}$ & 87.56 & 1.030 & -1.498 & -11.164 & -8.317 & 10.427 & -0.963 & -10.147 \\
\hline $\begin{array}{l}\text { Processed fruits } \\
\text { and vegetables }\end{array}$ & 29.39 & 1.003 & -0.580 & -1.593 & -14.580 & 3.603 & 0.566 & -11.354 \\
\hline $\begin{array}{l}\text { Condiments / } \\
\text { Spices }\end{array}$ & 104.65 & 1.001 & -0.150 & -1.317 & -7.307 & 0.101 & 1.850 & -3.125 \\
\hline Sweeteners & $\begin{array}{r}\text { Initial pe } \\
\text { Sweeteners } \\
\text { (lb }\end{array}$ & $\begin{array}{l}\text { Capita } \\
\text { onsumption } \\
\text { ) }\end{array}$ & $\begin{array}{r}\text { Swe } \\
\text { Consump } \\
\text { Cha }\end{array}$ & $\begin{array}{l}\text { ners } \\
\text { Quantity } \\
\text { (\%) }\end{array}$ & $\begin{array}{l}\text { Initial per Ca| } \\
\text { Consumpti }\end{array}$ & $\begin{array}{l}\text { ta Sweeteners } \\
\text { n (dollars) }\end{array}$ & $\begin{array}{r}\text { Sweeteners } \\
\text { Value C }\end{array}$ & $\begin{array}{l}\text { ansumption } \\
\text { ange (\%) }\end{array}$ \\
\hline $\begin{array}{l}\text { All Sweeteners } \\
\text { (sugar equivalent) }^{b}\end{array}$ & 105 & & & & 22 & & & 133 \\
\hline Sugars & 61. & & & & 13 & & & 498 \\
\hline Corn Sweeteners & 54. & & & & & & & 823 \\
\hline Other Sweeteners & 2.8 & & & & & & & 46 \\
\hline
\end{tabular}




\begin{tabular}{|c|c|c|c|c|}
\hline $\begin{array}{l}\text { Artificial } \\
\text { Sweeteners }\end{array}$ & 0.54 & 1.322 & 0.61 & 1.322 \\
\hline $\begin{array}{l}\text { Real Expenditure } \\
\text { on Nine Foods }\end{array}$ & Initial per $\mathrm{C}$ & ure (dollars) & \multicolumn{2}{|c|}{ Real Expenditure Change (\%) } \\
\hline & & & & \\
\hline Welfare & \multicolumn{4}{|c|}{ Market Welfare Change } \\
\hline $\begin{array}{l}\text { EV (million } \\
\text { dollars) }\end{array}$ & \multicolumn{4}{|c|}{-1676.89600} \\
\hline $\begin{array}{l}\text { Per capita EV } \\
\text { (dollars) }\end{array}$ & \multicolumn{4}{|c|}{-5.98315} \\
\hline EV/Income (\%) & \multicolumn{4}{|c|}{0.03187} \\
\hline
\end{tabular}

a. Initial prices are normalized to \$1/unit.

b. See Table 10 footnote $b$. 
Table 14. Changes for All Households with Tax on the Price of Individual Sweeteners for Nine Sweetener-Intensive Foods

\begin{tabular}{|c|c|c|c|c|c|}
\hline \multirow{4}{*}{ Food } & \multirow{4}{*}{$\begin{array}{l}\text { Initial per Capita Food } \\
\text { Demand (dollars) }^{\text {a }}\end{array}$} & \multicolumn{2}{|c|}{$\begin{array}{c}\text { Tax on the Price of } \\
\text { Sugars }\end{array}$} & \multicolumn{2}{|c|}{$\begin{array}{l}\text { Tax on the Price of } \\
\text { Corn Sweeteners }\end{array}$} \\
\hline & & \multicolumn{4}{|c|}{ Tax Rate } \\
\hline & & \multicolumn{2}{|c|}{$61.245 \%$} & \multicolumn{2}{|c|}{$156.849 \%$} \\
\hline & & $\begin{array}{l}\text { Price } \\
\text { with } \\
\text { Tax } \\
\end{array}$ & $\begin{array}{c}\text { Food } \\
\text { Demand } \\
\text { Change (\%) }\end{array}$ & $\begin{array}{l}\text { Price } \\
\text { with } \\
\text { Tax } \\
\end{array}$ & $\begin{array}{c}\text { Food } \\
\text { Demand } \\
\text { Change (\%) }\end{array}$ \\
\hline Milk & 100.44 & 1.002 & -0.182 & 1.007 & -0.733 \\
\hline Cheese & 65.55 & 1.000 & 0.101 & 1.001 & -0.138 \\
\hline Ice cream / yogurt & 27.39 & 1.005 & -0.488 & 1.010 & -0.825 \\
\hline $\begin{array}{l}\text { Breakfast cereal / } \\
\text { Bakery }\end{array}$ & 149.78 & 1.009 & -0.330 & 1.004 & -0.171 \\
\hline Soft drink & 118.41 & 1.001 & -0.092 & 1.032 & -3.025 \\
\hline Juice & 42.96 & 1.001 & 0.189 & 1.007 & -0.525 \\
\hline Sweetener products & 87.56 & 1.053 & -2.633 & 1.010 & -0.458 \\
\hline $\begin{array}{l}\text { Processed fruits and } \\
\text { vegetables }\end{array}$ & 29.39 & 1.001 & -0.061 & 1.007 & -1.450 \\
\hline Condiments / Spices & 104.65 & 1.001 & -0.142 & 1.002 & -0.204 \\
\hline Sweeteners & $\begin{array}{l}\text { Initial per Capita } \\
\text { Sweeteners } \\
\text { Consumption (lbs) } \\
\end{array}$ & \multicolumn{4}{|c|}{$\begin{array}{l}\text { Sweeteners Consumption Quantity Change } \\
(\mathbf{( \% )}\end{array}$} \\
\hline $\begin{array}{l}\text { All Sweeteners } \\
\text { (sugar equivalent) }^{\mathrm{b}}\end{array}$ & 105.69 & & 10.000 & & -10.000 \\
\hline Sugars & 61.90 & & 22.089 & & 7.727 \\
\hline Corn Sweeteners & 54.81 & & 7.405 & & -37.636 \\
\hline Other Sweeteners & 2.86 & & 2.809 & & 4.729 \\
\hline Artificial Sweeteners & 0.54 & & 0.203 & & 3.117 \\
\hline Sweeteners & $\begin{array}{c}\text { Initial per Capita } \\
\text { Sweeteners } \\
\text { Consumption (dollars) } \\
\end{array}$ & \multicolumn{4}{|c|}{ Sweeteners Consumption Value Change (\%) } \\
\hline All Sweeteners & 22.66 & & 20.312 & & 31.635 \\
\hline Sugars & 13.80 & & 29.226 & & 7.727 \\
\hline Corn Sweeteners & 7.31 & & 7.405 & & 82.578 \\
\hline Other Sweeteners & 0.94 & & 2.809 & & 4.729 \\
\hline Artificial Sweeteners & 0.61 & & 0.203 & & 3.117 \\
\hline $\begin{array}{l}\text { Real Expenditure on } \\
\text { Nine Foods }\end{array}$ & $\begin{array}{l}\text { Initial per Capita Real } \\
\text { Expenditure (dollars) } \\
\end{array}$ & \multicolumn{4}{|c|}{ Real Expenditure Change (\%) } \\
\hline & 726.13 & & 0.461 & & 0.094 \\
\hline Welfare & & \multicolumn{4}{|c|}{ Market Welfare Change } \\
\hline EV (million dollars) & & & 864.867 & & 1934.313 \\
\hline $\begin{array}{l}\text { Per capita EV } \\
\text { (dollars) }\end{array}$ & & & -6.654 & & -6.902 \\
\hline EV/Income (\%) & & & 0.035 & & 0.037 \\
\hline
\end{tabular}

a. Initial prices are normalized to \$1/unit.

b. See Table 10 footnote b. 
Appendix A. Categories of Sweetener-Intensive Intermediate Materials in the U.S. Food Manufacturing Industry

\begin{tabular}{|c|c|c|c|c|}
\hline $\begin{array}{l}\text { Selected } \\
\text { intermediate } \\
\text { products }\end{array}$ & $\begin{array}{c}\text { Repre- } \\
\text { sentative } \\
\text { industry } \\
\text { NAICS } \\
\text { code }\end{array}$ & $\begin{array}{l}\text { Represent- } \\
\text { ative } \\
\text { industry } \\
\text { NAICS } \\
\text { definition }\end{array}$ & $\begin{array}{c}\text { Material } \\
\text { code }^{\mathbf{a}}\end{array}$ & Materials consumed $^{\mathrm{a}}$ \\
\hline \multirow{2}{*}{ Fluid milk } & \multirow{2}{*}{311511} & \multirow{2}{*}{$\begin{array}{l}\text { Fluid milk } \\
\text { mfg }\end{array}$} & 31151101 & Fluid skim milk \\
\hline & & & 31151103 & Cream \\
\hline \multirow[t]{2}{*}{ Cheese } & \multirow[t]{2}{*}{311513} & \multirow[t]{2}{*}{ Cheese mfg } & 31151301 & $\begin{array}{l}\text { Natural cheese (excluding } \\
\text { cottage cheese) }\end{array}$ \\
\hline & & & 31151305 & Processed cheese \\
\hline \multirow{4}{*}{$\begin{array}{l}\text { Dry, } \\
\text { condensed } \\
\text { and } \\
\text { evaporated } \\
\text { milk }\end{array}$} & \multirow{4}{*}{311514} & \multirow{4}{*}{$\begin{array}{l}\text { Dry, } \\
\text { condensed, } \\
\text { and } \\
\text { evaporated } \\
\text { dairy product } \\
\text { mfg }\end{array}$} & 31151401 & $\begin{array}{l}\text { Condensed and evaporated } \\
\text { milk }\end{array}$ \\
\hline & & & 31151403 & $\begin{array}{l}\text { Whey (liquid, concentrated, } \\
\text { and dried) and modified whey } \\
\text { products }\end{array}$ \\
\hline & & & 31151405 & $\begin{array}{l}\text { Milk and milk replacers (dry } \\
\text { milk, dry whey, blends, soy } \\
\text { whey, etc.) }\end{array}$ \\
\hline & & & 31151407 & Dry milk \\
\hline \multirow{5}{*}{$\begin{array}{l}\text { Ice cream } \\
\text { and yogurt } \\
\text { mixes }\end{array}$} & \multirow{5}{*}{311520} & \multirow{5}{*}{$\begin{array}{l}\text { Ice cream } \\
\text { and frozen } \\
\text { dessert mfg }\end{array}$} & 31152001 & $\begin{array}{l}\text { Ice cream mixes (excluding } \\
\text { low-fat and nonfat) }\end{array}$ \\
\hline & & & 31152003 & Sherbet mix \\
\hline & & & 31152005 & Ice cream mix, low-fat \\
\hline & & & 31152007 & Yogurt mix \\
\hline & & & 31152009 & Ice cream mix, nonfat \\
\hline \multirow{4}{*}{$\begin{array}{l}\text { Prepared } \\
\text { mixes }\end{array}$} & \multirow{4}{*}{311822} & \multirow{4}{*}{$\begin{array}{l}\text { Flour mixes } \\
\text { and dough } \\
\text { mfg from } \\
\text { purchased } \\
\text { flour }\end{array}$} & 31100005 & $\begin{array}{l}\text { Prepared doughnut mixes, cake } \\
\text { and yeast types }\end{array}$ \\
\hline & & & 31100007 & $\begin{array}{l}\text { Prepared bread mixes, } \\
\text { including franchise mixes }\end{array}$ \\
\hline & & & 31100009 & Prepared cake mixes \\
\hline & & & 31100011 & $\begin{array}{l}\text { Other prepared mixes, } \\
\text { including sweet-goods }\end{array}$ \\
\hline \multirow{6}{*}{ Flour } & \multirow{6}{*}{311211} & \multirow{6}{*}{ Flour milling } & 31121101 & Wheat flour \\
\hline & & & 31121103 & $\begin{array}{l}\text { Wheat flour, cookie and } \\
\text { cracker type (excluding } \\
\text { prepared mixes) }\end{array}$ \\
\hline & & & 31121105 & $\begin{array}{l}\text { Wheat flour, other (including } \\
\text { whole wheat, and clear flour), } \\
\text { excluding prepared mixes }\end{array}$ \\
\hline & & & 31121109 & $\begin{array}{l}\text { Wheat flour, cake type } \\
\text { (excluding prepared mixes) }\end{array}$ \\
\hline & & & 31121111 & $\begin{array}{l}\text { Wheat flour, white bread type } \\
\text { (excluding prepared mixes) }\end{array}$ \\
\hline & & & 31121119 & Corn grits \\
\hline
\end{tabular}




\begin{tabular}{|c|c|c|c|c|}
\hline & & & 31121121 & Corn meal and flakes \\
\hline & & & 31121131 & Prepared flour mixes \\
\hline & & & 31121133 & Flour (excluding wheat) \\
\hline & & & 31122121 & Wheat gluten \\
\hline & & Flavoring & 31193001 & $\begin{array}{l}\text { Liquid beverage base } \\
\text { concentrates with some juice } \\
\text { content (finished drink basis) }\end{array}$ \\
\hline $\begin{array}{l}\text { Liquid } \\
\text { beverage } \\
\text { base }\end{array}$ & 311930 & $\begin{array}{l}\text { syrup and } \\
\text { concentrate } \\
\text { mfg }\end{array}$ & 31193003 & $\begin{array}{l}\text { Other liquid beverage base } \\
\text { concentrates (finished drink } \\
\text { basis) }\end{array}$ \\
\hline & & & 31193005 & $\begin{array}{l}\text { Liquid beverage base syrups } \\
\text { (finished drink basis) }\end{array}$ \\
\hline & & Chocolate & 31132001 & $\begin{array}{l}\text { Chocolate (compounds, cocoa, } \\
\text { chocolate liquor, coatings, } \\
\text { chocolate flavoring, etc.) }\end{array}$ \\
\hline & & & 31132003 & \begin{tabular}{|l} 
Chocolate coatings \\
\end{tabular} \\
\hline Chocolate & 311320 & $\begin{array}{l}\text { confectionery } \\
\text { mfg from }\end{array}$ & 31132005 & $\begin{array}{l}\text { Unsweetened chocolate } \\
\text { (chocolate liquor) }\end{array}$ \\
\hline & & cacao beans & 31132007 & $\begin{array}{l}\text { Cocoa, pressed cake and } \\
\text { powder }\end{array}$ \\
\hline & & & 31132009 & Cocoa butter \\
\hline
\end{tabular}

Source: 2002 Economic Census Industry Series Reports (Manufacturing).

a. Material code and material categories are based on Table 7 in the 2002 Economic Census Industry Series Reports (Manufacturing). 
Appendix B. Quantities of Sweeteners in Nine Target Sweetener-Intensive U.S. Food Manufacturing Industry

\begin{tabular}{|c|c|c|c|c|c|}
\hline \multirow[b]{2}{*}{ Food } & \multicolumn{5}{|c|}{ Quantities of Sweeteners (million lbs) } \\
\hline & $\begin{array}{c}\text { Sugars } \\
(22.29 \\
\text { cents/lb) }\end{array}$ & $\begin{array}{c}\text { Corn } \\
\text { Sweeteners } \\
(13.34 \\
\text { cents/lb) }\end{array}$ & $\begin{array}{c}\text { Other } \\
\text { Sweeteners } \\
(32.95 \\
\text { cents/lb) }\end{array}$ & $\begin{array}{c}\text { Artificial } \\
\text { Sweeteners } \\
(112.04 \\
\text { cents/lb) }\end{array}$ & $\begin{array}{c}\text { All } \\
\text { Sweeteners }^{\mathrm{a}}\end{array}$ \\
\hline Milk & 653056.21 & 1535477.40 & 0.00 & 99.55 & 1804763.81 \\
\hline Cheese & 31426.79 & 110704.39 & 0.00 & 0.00 & 114455.09 \\
\hline Ice cream / yogurt & 394810.52 & 586084.41 & 0.00 & 144.84 & 834518.67 \\
\hline $\begin{array}{l}\text { Breakfast cereal / } \\
\text { Bakery }\end{array}$ & 3555864.25 & 1282891.04 & 359568.28 & 11930.98 & 4799639.72 \\
\hline Soft drink & 260497.98 & 8350652.17 & 130446.13 & 30119.60 & 6651441.31 \\
\hline Juice & 117403.74 & 646109.47 & 0.00 & 0.00 & 601985.85 \\
\hline $\begin{array}{l}\text { Sweetener } \\
\text { products }\end{array}$ & 11886958.58 & 1912122.36 & 57945.23 & 100844.09 & 13465353.37 \\
\hline $\begin{array}{l}\text { Processed fruits } \\
\text { and vegetables }\end{array}$ & 82963.98 & 488507.45 & 0.00 & 0.00 & 449344.57 \\
\hline $\begin{array}{l}\text { Condiments / } \\
\text { Spices }\end{array}$ & 367113.35 & 448513.82 & 252298.66 & 8260.59 & 900983.29 \\
\hline
\end{tabular}

Source: 2002 Economic Census Industry Series Reports (Manufacturing).

a. Converted to sugar equivalent based on sweeteners' caloric content (see Table 10, footnote b). 


\section{Appendix C. Calculation of Consumption Adjustment Ratio from Food Availability Data}

The food availability (food disappearance) data compiled by USDA/ERS is a measure of the amount of food available for human consumption in the United States, and derived from estimates of food supplies moving from production to domestic consumption. Food for human consumption is not measured directly by the food disappearance data. Instead, food disappearance is calculated as the difference between available commodity supplies (production, imports, and beginning stocks) and nonfood use (farm inputs, exports, ending stocks) with adjustment for losses. Food availability data measure food supplies available for consumption for all the outlets, both at home and away from home.

As a measure of final consumption, the food availability data measure the use of raw and semi-processed agricultural commodities from which final food products are made. For the majority of foods, the association between the categories in the food availability data and the final consumption forms is fairly direct; examples are dairy products and juice. However, for some categories, the forms of final products are unknown, and little data are available on supplies of further processed foods.

The food supply data for the grain group are available only in their primary formwhite and wheat flour, durum flour, rice, oat, corn, barley, and rye flour. They are presented in grain equivalents and do not estimate food consumption very precisely. Hence, food availability data provide limited information on the final products consumed in this group. Instead of measuring an estimate of consumption of the pasta, oatmeal, breakfast cereals, bread, and grits, data are only available as supplies of flour, oats, corn, and barley.

In order to obtain the adjustment ratio of the Breakfast cereal and Bakery products group, the adjusted ratios of wheat flour, rye flour, rice, corn for food use (cereals and other products), oat, and barley are averaged by their disappearance data weight to get a weighted average adjustment ratio 0.75 for this whole group and applied to measure the grain ingredients. This corresponds to the "Flour milling” (NAICS 311211), "Breakfast Cereal Manufacturing” (NAICS 3111230), “Commercial Bakeries” (NAICS 311812), “Frozen Cakes, Pies, and Other Pastries Manufacturing” (NAICS 311813), “Cookie and Cracker Manufacturing” (NAICS 311821), “Flour Mixes and Dough Manufacturing from Purchased Flour” (NAICS 311822). 
Appendix D. Price Elasticity between the Sweeteners for Nine Sweetener-Intensive Foods ${ }^{\mathrm{a}}$

\begin{tabular}{|c|c|c|c|c|c|c|}
\hline Food & Sweeteners & Sugars & $\begin{array}{c}\text { Corn } \\
\text { Sweeteners }\end{array}$ & $\begin{array}{c}\text { Other } \\
\text { Sweeteners }\end{array}$ & $\begin{array}{c}\text { Artificial } \\
\text { Sweeteners }\end{array}$ & $\begin{array}{l}\text { All other } \\
\text { inputs }\end{array}$ \\
\hline \multirow{5}{*}{ Milk } & Sugars & -0.4800000 & $0.3000000^{C}$ & $0.0000700^{\mathrm{d}}$ & $0.0001400^{\mathrm{d}}$ & 0.1797900 \\
\hline & $\begin{array}{c}\text { Corn } \\
\text { Sweeteners }\end{array}$ & 0.2131978 & -0.4800000 & $0.0000700^{\mathrm{d}}$ & $0.0001400^{\mathrm{d}}$ & 0.2665922 \\
\hline & $\begin{array}{c}\text { Other } \\
\text { Sweeteners }\end{array}$ & 0.0309245 & 0.0435153 & -0.4800000 & $0.0001400^{\mathrm{d}}$ & 0.4054202 \\
\hline & $\begin{array}{c}\text { Artificial } \\
\text { Sweeteners }\end{array}$ & 0.1827121 & 0.2571023 & 0.0004136 & -0.4800000 & 0.0397721 \\
\hline & $\begin{array}{l}\text { All other } \\
\text { materials }\end{array}$ & 0.0009414 & 0.0019642 & 0.0000048 & 0.0000002 & -0.0029106 \\
\hline \multirow{5}{*}{ Cheese } & Sugars & -0.4800000 & $0.3000000^{C}$ & $0.0005000^{\mathrm{e}}$ & $0.0005000^{\mathrm{e}}$ & 0.1790000 \\
\hline & $\begin{array}{c}\text { Corn } \\
\text { Sweeteners }\end{array}$ & 0.1423019 & -0.4800000 & $0.0005000^{\mathrm{e}}$ & $0.0005000^{\mathrm{e}}$ & 0.3366981 \\
\hline & $\begin{array}{c}\text { Other } \\
\text { Sweeteners }\end{array}$ & 0.0106298 & 0.0224097 & -0.4800000 & $0.0005000^{\mathrm{e}}$ & 0.4464605 \\
\hline & $\begin{array}{c}\text { Artificial } \\
\text { Sweeteners }\end{array}$ & 0.0031261 & 0.0065905 & 0.0001470 & -0.4800000 & 0.4701363 \\
\hline & $\begin{array}{l}\text { All other } \\
\text { materials }\end{array}$ & 0.0000683 & 0.0002710 & 0.0000080 & 0.0000287 & -0.0003760 \\
\hline \multirow{5}{*}{$\begin{array}{l}\text { Ice cream / } \\
\text { yogurt }\end{array}$} & Sugars & -0.4800000 & $0.3000000^{\mathrm{C}}$ & $0.0002000^{\mathrm{d}}$ & $0.0004000^{\mathrm{d}}$ & 0.1794000 \\
\hline & $\begin{array}{c}\text { Corn } \\
\text { Sweeteners }\end{array}$ & 0.3376790 & -0.4800000 & $0.0002000^{\mathrm{d}}$ & $0.0004000^{\mathrm{d}}$ & 0.1417210 \\
\hline & $\begin{array}{c}\text { Other } \\
\text { Sweeteners }\end{array}$ & 0.0534163 & 0.0474559 & -0.4800000 & $0.0004000^{\mathrm{d}}$ & 0.3787278 \\
\hline & $\begin{array}{c}\text { Artificial } \\
\text { Sweeteners }\end{array}$ & 0.2169210 & 0.1927165 & 0.0008122 & -0.4800000 & 0.0695503 \\
\hline & $\begin{array}{l}\text { All other } \\
\text { materials }\end{array}$ & 0.0021022 & 0.0014754 & 0.0000166 & 0.0000015 & -0.0035958 \\
\hline \multirow{5}{*}{$\begin{array}{l}\text { Breakfast } \\
\text { cereal / } \\
\text { Bakery }\end{array}$} & Sugars & -0.4800000 & $0.1000000^{\mathrm{f}}$ & $0.0100000^{\mathrm{g}}$ & $0.0050000^{\mathrm{h}}$ & 0.3650000 \\
\hline & $\begin{array}{c}\text { Corn } \\
\text { Sweeteners }\end{array}$ & 0.4631372 & -0.4800000 & $0.0100000^{\mathrm{g}}$ & $0.0050000^{\mathrm{h}}$ & 0.0018628 \\
\hline & $\begin{array}{c}\text { Other } \\
\text { Sweeteners }\end{array}$ & 0.0668988 & 0.0144447 & -0.4800000 & $0.0050000^{\mathrm{h}}$ & 0.3936565 \\
\hline & $\begin{array}{c}\text { Artificial } \\
\text { Sweeteners }\end{array}$ & 0.2964668 & 0.0640127 & 0.0443157 & -0.4800000 & 0.0752048 \\
\hline & $\begin{array}{l}\text { All other } \\
\text { materials }\end{array}$ & 0.0070761 & 0.0000078 & 0.0011408 & 0.0000246 & -0.0082493 \\
\hline \multirow{3}{*}{ Soft drink } & Sugars & -0.4800000 & $0.3000000^{\mathrm{C}}$ & $0.0100000^{\mathrm{g}}$ & $0.0050000^{\mathrm{h}}$ & 0.1650000 \\
\hline & $\begin{array}{c}\text { Corn } \\
\text { Sweeteners }\end{array}$ & 0.0156372 & -0.4800000 & $0.0100000^{\mathrm{g}}$ & $0.0050000^{\mathrm{h}}$ & 0.4493628 \\
\hline & $\begin{array}{c}\text { Other } \\
\text { Sweeteners }\end{array}$ & 0.0135091 & 0.2591729 & -0.4800000 & $0.0050000^{\mathrm{h}}$ & 0.2023179 \\
\hline
\end{tabular}




\begin{tabular}{|c|c|c|c|c|c|c|}
\hline & $\begin{array}{c}\text { Artificial } \\
\text { Sweeteners }\end{array}$ & 0.0086032 & 0.1650532 & 0.0063685 & -0.4800000 & 0.2999751 \\
\hline & $\begin{array}{l}\text { All other } \\
\text { materials }\end{array}$ & 0.0003000 & 0.0156733 & 0.0002723 & 0.0003170 & -0.0165625 \\
\hline \multirow{5}{*}{ Juice } & Sugars & -0.4800000 & $0.3000000^{C}$ & $0.0005000^{\mathrm{e}}$ & $0.0005000^{\mathrm{e}}$ & 0.1790000 \\
\hline & $\begin{array}{c}\text { Corn } \\
\text { Sweeteners }\end{array}$ & 0.0910859 & -0.4800000 & $0.0005000^{\mathrm{e}}$ & $0.0005000^{\mathrm{e}}$ & 0.3879141 \\
\hline & $\begin{array}{c}\text { Other } \\
\text { Sweeteners }\end{array}$ & 0.0397106 & 0.1307906 & -0.4800000 & $0.0005000^{\mathrm{e}}$ & 0.3089988 \\
\hline & $\begin{array}{c}\text { Artificial } \\
\text { Sweeteners }\end{array}$ & 0.0116786 & 0.0384644 & 0.0001470 & -0.4800000 & 0.4297100 \\
\hline & $\begin{array}{l}\text { All other } \\
\text { materials }\end{array}$ & 0.0003928 & 0.0028033 & 0.0000085 & 0.0000404 & -0.0032450 \\
\hline \multirow{5}{*}{$\begin{array}{l}\text { Sweetener } \\
\text { products }\end{array}$} & Sugars & -0.4800000 & $0.0400000^{\mathrm{f}}$ & $0.0030000^{\mathrm{f}}$ & $0.0010000^{\mathrm{f}}$ & 0.4360000 \\
\hline & $\begin{array}{c}\text { Corn } \\
\text { Sweeteners }\end{array}$ & 0.4154983 & -0.4800000 & $0.0030000^{\mathrm{f}}$ & $0.0010000^{\mathrm{f}}$ & 0.0605017 \\
\hline & $\begin{array}{c}\text { Other } \\
\text { Sweeteners }\end{array}$ & 0.4163216 & 0.0400793 & -0.4800000 & $0.0010000^{f}$ & 0.0225991 \\
\hline & $\begin{array}{c}\text { Artificial } \\
\text { Sweeteners }\end{array}$ & 0.0234508 & 0.0022576 & 0.0001690 & -0.4800000 & 0.4541226 \\
\hline & $\begin{array}{l}\text { All other } \\
\text { materials }\end{array}$ & 0.0537199 & 0.0007176 & 0.0000201 & 0.0023860 & -0.0568436 \\
\hline \multirow{5}{*}{$\begin{array}{l}\text { Processed } \\
\text { fruits and } \\
\text { vegetables }\end{array}$} & Sugars & -0.4800000 & $0.3000000^{C}$ & $0.0005000^{\mathrm{e}}$ & $0.0005000^{\mathrm{e}}$ & 0.1790000 \\
\hline & $\begin{array}{c}\text { Corn } \\
\text { Sweeteners }\end{array}$ & 0.0851322 & -0.4800000 & $0.0005000^{\mathrm{e}}$ & $0.0005000^{\mathrm{e}}$ & 0.3938678 \\
\hline & $\begin{array}{c}\text { Other } \\
\text { Sweeteners }\end{array}$ & 0.0280617 & 0.0988876 & -0.4800000 & $0.0005000^{\mathrm{e}}$ & 0.3525507 \\
\hline & $\begin{array}{c}\text { Artificial } \\
\text { Sweeteners }\end{array}$ & 0.0082527 & 0.0290820 & 0.0001470 & -0.4800000 & 0.4425183 \\
\hline & $\begin{array}{l}\text { All other } \\
\text { materials }\end{array}$ & 0.0004060 & 0.0031483 & 0.0000142 & 0.0000608 & -0.0036294 \\
\hline \multirow{5}{*}{$\begin{array}{l}\text { Condiments } \\
\text { / Spices }\end{array}$} & Sugars & -0.4800000 & $0.3000000^{C}$ & $0.0100000^{\mathrm{g}}$ & $0.0050000^{\mathrm{h}}$ & 0.1650000 \\
\hline & $\begin{array}{c}\text { Corn } \\
\text { Sweeteners } \\
\end{array}$ & 0.4102984 & -0.4800000 & $0.0100000^{\mathrm{g}}$ & $0.0050000^{\mathrm{h}}$ & 0.0547016 \\
\hline & $\begin{array}{c}\text { Other } \\
\text { Sweeteners }\end{array}$ & 0.0098433 & 0.0071972 & -0.4800000 & $0.0050000^{\mathrm{h}}$ & 0.4579596 \\
\hline & $\begin{array}{c}\text { Artificial } \\
\text { Sweeteners }\end{array}$ & 0.0442075 & 0.0323234 & 0.0449114 & -0.4800000 & 0.3585577 \\
\hline & $\begin{array}{l}\text { All other } \\
\text { materials }\end{array}$ & 0.0004640 & 0.0001125 & 0.0013084 & 0.0001141 & -0.0019990 \\
\hline
\end{tabular}

Source: 2002 Economic Census Industry Series Reports (Manufacturing).

a. The own-price elasticities of the sweeteners are set to -0.48 . The lower triangle elements are derived from the upper triangle elements because their ratios are proportional to their cost shares' ratio based on the definition of Hessian matrix in the production.

b. The price elasticities of sweeteners to "All Other Inputs” are derived using the homogeneity property 
of the Hessian matrix from the output-constant cost function of food manufacturers with respect to prices. c. The cross-price elasticity of Sugars with respect to Corn Sweeteners is set to 0.30.

d. There is no usage of Other Sweeteners in the final products "Milk" and "Ice cream / yogurt." For "Milk," the cross-price elasticities of Sugars and Corn Sweeteners with respect to Other Sweeteners are both set to 0.00007; the cross-price elasticities of Sugars, Corn Sweeteners, and Other Sweeteners with respect to Artificial Sweeteners are all set to 0.00014. For "Ice cream / yogurt," these two values are set to 0.0002 and 0.0004 .

e. If neither Other Sweeteners nor Artificial Sweeteners is used, the sweeteners' cross-price elasticities in the upper triangle are all set to 0.0005 except the one between Sugars and Corn Sweeteners.

f. The concavity curvature of the cost function requires that the Hessian matrix be negative semi-definite. When some sweeteners' cost shares are very small or equal to zero, the corresponding elements in the upper-triangle of the input price elasticity matrix need to be set to smaller values to satisfy the homogeneity condition.

g. The cross-price elasticities of Sugars and Corn Sweeteners with respect to Other Sweeteners are both set to 0.01 .

h. The cross-price elasticities of Sugars, Corn Sweeteners, and Other Sweeteners with respect to Artificial Sweeteners are all set to 0.005 . 
Appendix E. Parameters in LinQuad Demand Systems for Nine Sweetener-Intensive Foods

E -1 Parameters of the income term $(\chi)$ and linear price term $(\varepsilon)$ in the LinQuad Demand Systems

\begin{tabular}{|c|c|c|c|c|c|c|c|}
\hline \multirow[b]{3}{*}{ Food } & \multirow[b]{3}{*}{$\chi$} & \multicolumn{6}{|c|}{$\varepsilon$} \\
\hline & & $\varepsilon_{\text {All }}$ & $\varepsilon_{1}$ & $\varepsilon_{2}$ & $\varepsilon_{3}$ & $\varepsilon_{4}$ & $\varepsilon_{5}$ \\
\hline & & $\begin{array}{c}\text { All } \\
\text { household }\end{array}$ & $\begin{array}{c}\text { Lowest } \\
20 \% \\
\text { quintile }\end{array}$ & $\begin{array}{c}\text { Second } \\
20 \% \\
\text { quintile }\end{array}$ & $\begin{array}{c}\text { Third } \\
20 \% \\
\text { quintile }\end{array}$ & $\begin{array}{c}\text { Fourth } \\
20 \% \\
\text { quintile }\end{array}$ & $\begin{array}{c}\text { Highest } \\
20 \% \\
\text { quintile }\end{array}$ \\
\hline Milk & 0.00015 & 51062.05 & 8740.34 & 10004.52 & 9996.22 & 10855.01 & 11465.96 \\
\hline Cheese & 0.00077 & 35704.07 & 6449.18 & 6726.63 & 7202.93 & 7530.81 & 7794.53 \\
\hline Ice cream / yogurt & -0.00025 & 16535.57 & 2524.77 & 2799.56 & 3189.63 & 3591.33 & 4430.29 \\
\hline Breakfast cereal / Bakery & 0.00180 & 52595.44 & 9421.28 & 10179.61 & 10421.44 & 11171.35 & 11401.76 \\
\hline Soft drink & -0.00020 & 67038.67 & 10978.79 & 12084.01 & 13096.47 & 14413.70 & 16465.71 \\
\hline Juice & 0.00087 & 16840.66 & 3313.71 & 3479.41 & 3454.00 & 3480.93 & 3112.61 \\
\hline Sweetener products & 0.00022 & 33349.38 & 5275.03 & 5842.78 & 6629.58 & 7235.25 & 8366.75 \\
\hline Processed fruits and vegetables & 0.00076 & 19535.95 & 4017.12 & 4079.74 & 4051.03 & 3966.38 & 3421.69 \\
\hline Condiments / Spices & 0.00068 & 56409.76 & 9464.30 & 10454.22 & 11319.98 & 12151.45 & 13019.81 \\
\hline
\end{tabular}

Source: USDA/ERS, 2008a and Chouinard et al. 2010.

Note: Elasticities for final products used in the calculation are from Chouinard et al. 2010 (see Table 6 and 7). 
E -2 Parameter matrix of the quadratic price term $\left(V_{A l l}\right)$ in the LinQuad Demand Systems for All households

\begin{tabular}{|c|c|c|c|c|c|c|c|c|c|}
\hline Food & Milk & Cheese & $\begin{array}{c}\text { Ice } \\
\text { cream / } \\
\text { yogurt } \\
\end{array}$ & $\begin{array}{c}\text { Breakfast } \\
\text { cereal / } \\
\text { Bakery } \\
\end{array}$ & $\begin{array}{c}\text { Soft } \\
\text { drink }\end{array}$ & Juice & $\begin{array}{l}\text { Sweetener } \\
\text { products }\end{array}$ & $\begin{array}{l}\text { Processed } \\
\text { fruits and } \\
\text { vegetables }\end{array}$ & $\begin{array}{l}\text { Condiments/ } \\
\text { Spices }\end{array}$ \\
\hline Milk & -20396.35 & -749.33 & 0.00 & -786.49 & -1990.45 & 482.51 & 156.63 & -385.17 & 0.00 \\
\hline $\begin{array}{l}\text { Ice cream / } \\
\text { yogurt }\end{array}$ & 0.00 & -883.41 & -6399.86 & -276.29 & 0.00 & -37.95 & 0.00 & 0.00 & 0.00 \\
\hline $\begin{array}{l}\text { Breakfast } \\
\text { cereal / } \\
\text { Bakery }\end{array}$ & -786.49 & -681.62 & -276.29 & -19858.86 & 0.00 & 242.11 & 888.05 & 864.42 & 0.00 \\
\hline Soft drink & -1990.45 & 0.00 & 0.00 & 0.00 & -30764.59 & -101.04 & 0.00 & 0.00 & 0.00 \\
\hline Juice & 482.51 & -279.64 & -37.95 & 242.11 & -101.04 & -10257.30 & 597.97 & 219.56 & 0.00 \\
\hline $\begin{array}{l}\text { Sweetener } \\
\text { products }\end{array}$ & 156.63 & 685.06 & 0.00 & 888.05 & 0.00 & 597.97 & -12373.77 & 123.44 & 0.00 \\
\hline $\begin{array}{l}\text { Processed } \\
\text { fruits and } \\
\text { vegetables }\end{array}$ & -385.17 & 318.54 & 0.00 & 864.42 & 0.00 & 219.56 & 123.44 & -16236.25 & 0.00 \\
\hline
\end{tabular}

Source: Elasticities for final products used for the calculation are from USDA/ERS, 2008a and Chouinard et al. 2010 (see Tables 6 and 7). 
E -3 Parameter matrix of the quadratic price term $(V)$ in the LinQuad Demand Systems for Disaggregated Income Groups

\begin{tabular}{|l|c|c|c|c|c|c|c|c|c|}
\hline Food & Milk & Cheese & $\begin{array}{c}\text { Ice } \\
\text { cream / } \\
\text { yogurt }\end{array}$ & $\begin{array}{c}\text { Breakfast } \\
\text { cereal / } \\
\text { Bakery }\end{array}$ & $\begin{array}{c}\text { Soft } \\
\text { drink }\end{array}$ & Juice & $\begin{array}{c}\text { Sweetener } \\
\text { products }\end{array}$ & $\begin{array}{c}\text { Processed } \\
\text { fruits and } \\
\text { vegetables }\end{array}$ & $\begin{array}{c}\text { Condiments/ } \\
\text { Spices }\end{array}$ \\
\hline Milk & -4079.27 & -149.87 & 0.00 & -157.30 & -398.09 & 96.50 & 31.33 & -77.03 & 0.00 \\
\hline Cheese & -149.87 & -3922.62 & -176.68 & -136.32 & 0.00 & -55.93 & 137.01 & 63.71 & 0.00 \\
\hline $\begin{array}{l}\text { Ice cream / } \\
\text { yogurt }\end{array}$ & 0.00 & -176.68 & -1279.97 & -55.26 & 0.00 & -7.59 & 0.00 & 0.00 & 0.00 \\
\hline $\begin{array}{l}\text { Breakfast } \\
\text { cereal / } \\
\text { Bakery }\end{array}$ & -157.30 & -136.32 & -55.26 & -3971.77 & 0.00 & 48.42 & 177.61 & 172.88 \\
\hline Soft drink & -398.09 & 0.00 & 0.00 & 0.00 & -6152.92 & -20.21 & 0.00 & 0.00 & 0.00 \\
\hline Juice & 96.50 & -55.93 & -7.59 & 48.42 & -20.21 & -2051.46 & 119.59 & 43.91 & 0.00 \\
\hline $\begin{array}{l}\text { Sweetener } \\
\text { products }\end{array}$ & 31.33 & 137.01 & 0.00 & 177.61 & 0.00 & 119.59 & -2474.75 & 24.69 & 0.00 \\
\hline $\begin{array}{l}\text { Processed } \\
\text { fruits and } \\
\text { vegetables }\end{array}$ & -77.03 & 63.71 & 0.00 & 172.88 & 0.00 & 43.91 & 24.69 & -3247.25 \\
\hline $\begin{array}{l}\text { Condiments / } \\
\text { Spices }\end{array}$ & 0.00 & 0.00 & 0.00 & 0.00 & 0.00 & 0.00 & 0.00 & 0.00 \\
\hline
\end{tabular}

Source: Elasticities for final products used for the calculation are from USDA/ERS, 2008a and Chouinard et al. 2010 (see Tables 6 and 7). 


\section{Appendix F. Disaggregated Income Groups Marshallian Elasticities of Nine Target Sweetener-Intensive Foods}

F -1. Lowest 20\% Quintile of Income Marshallian Elasticities of Nine Target Sweetener-Intensive Foods

\begin{tabular}{|c|c|c|c|c|c|c|c|c|c|}
\hline Food & Milk & Cheese & $\begin{array}{c}\text { Ice } \\
\text { cream / } \\
\text { yogurt } \\
\end{array}$ & $\begin{array}{c}\text { Breakfast } \\
\text { cereal / } \\
\text { Bakery } \\
\end{array}$ & $\begin{array}{c}\text { Soft } \\
\text { drink }\end{array}$ & Juice & $\begin{array}{c}\text { Sweetener } \\
\text { products }\end{array}$ & $\begin{array}{l}\text { Processed } \\
\text { fruits and } \\
\text { vegetables }\end{array}$ & $\begin{array}{c}\text { Condiments/ } \\
\text { Spices }\end{array}$ \\
\hline Milk & -1.01280 & -0.03729 & -0.00004 & -0.03926 & -0.09899 & 0.02390 & 0.00765 & -0.01916 & -0.00013 \\
\hline $\begin{array}{l}\text { Ice cream / } \\
\text { yogurt }\end{array}$ & 0.00104 & -0.18173 & -1.32049 & -0.05559 & 0.00115 & -0.00744 & 0.00086 & 0.00026 & 0.00088 \\
\hline $\begin{array}{l}\text { Breakfast } \\
\text { cereal / } \\
\text { Bakery }\end{array}$ & -0.02857 & -0.02437 & -0.00991 & -0.69160 & -0.00138 & 0.00795 & 0.02982 & 0.02972 & -0.00105 \\
\hline Soft drink & -0.09073 & 0.00010 & 0.00005 & 0.00025 & -1.40488 & -0.00455 & 0.00015 & 0.00005 & 0.00015 \\
\hline Juice & 0.05774 & -0.03590 & -0.00525 & 0.02710 & -0.01491 & -1.27415 & 0.07246 & 0.02672 & -0.00181 \\
\hline $\begin{array}{l}\text { Sweetener } \\
\text { products }\end{array}$ & 0.00916 & 0.04109 & -0.00007 & 0.05309 & -0.00030 & 0.03590 & -0.74508 & 0.00736 & -0.00023 \\
\hline $\begin{array}{l}\text { Processed } \\
\text { fruits and } \\
\text { vegetables }\end{array}$ & -0.07235 & 0.05605 & -0.00069 & 0.15243 & -0.00302 & 0.03866 & 0.02005 & -2.93468 & -0.00231 \\
\hline
\end{tabular}

Source: Elasticities for final products used for the calculation are from USDA/ERS, 2008a and Chouinard et al. 2010 (see Tables 6 and 7). 
F -2. Second 20\% Quintile of Income Marshallian Elasticities of Nine Target Sweetener-Intensive Foods

\begin{tabular}{|l|c|c|c|c|c|c|c|c|c|}
\hline Food & Milk & Cheese & $\begin{array}{c}\text { Ice } \\
\text { cream / } \\
\text { yogurt }\end{array}$ & $\begin{array}{c}\text { Breakfast } \\
\text { cereal / } \\
\text { Bakery }\end{array}$ & $\begin{array}{c}\text { Soft } \\
\text { drink }\end{array}$ & Juice & $\begin{array}{c}\text { Sweetener } \\
\text { products }\end{array}$ & $\begin{array}{c}\text { Processed } \\
\text { fruits and } \\
\text { vegetables }\end{array}$ & $\begin{array}{c}\text { Condiment/ } \\
\text { Spices }\end{array}$ \\
\hline Milk & -0.76487 & -0.02817 & -0.00004 & -0.02967 & -0.07478 & 0.01804 & 0.00576 & -0.01447 & -0.00012 \\
\hline Cheese & -0.05478 & -1.39643 & -0.06322 & -0.05023 & -0.00152 & -0.02036 & 0.04769 & 0.02238 & -0.00120 \\
\hline $\begin{array}{l}\text { Ice cream / } \\
\text { yogurt }\end{array}$ & 0.00113 & -0.14992 & -1.08972 & -0.04571 & 0.00119 & -0.00611 & 0.00083 & 0.00023 & 0.00094 \\
\hline $\begin{array}{l}\text { Breakfast } \\
\text { cereal / } \\
\text { Bakery }\end{array}$ & -0.02379 & -0.02008 & -0.00821 & -0.56806 & -0.00141 & 0.00648 & 0.02434 & 0.02438 & -0.00112 \\
\hline Soft drink & -0.07313 & 0.00009 & 0.00005 & 0.00023 & -1.13307 & -0.00366 & 0.00014 & 0.00004 & 0.00016 \\
\hline Juice & 0.04561 & -0.02881 & -0.00432 & 0.02133 & -0.01240 & -1.01840 & 0.05767 & 0.02133 & -0.00188 \\
\hline $\begin{array}{l}\text { Sweetener } \\
\text { products }\end{array}$ & 0.00763 & 0.03453 & -0.00007 & 0.04459 & -0.00031 & 0.03017 & -0.62647 & 0.00619 & -0.00025 \\
\hline $\begin{array}{l}\text { Processed } \\
\text { fruits and } \\
\text { vegetables }\end{array}$ & -0.05877 & 0.04484 & -0.00071 & 0.12194 & -0.00304 & 0.03094 & 0.01578 & -2.35566 \\
\hline $\begin{array}{l}\text { Condiments / } \\
\text { Spices }\end{array}$ & -0.00077 & -0.00036 & -0.00019 & -0.00091 & -0.00080 & -0.00024 & -0.00056 & -0.00015 & -1.31214 \\
\hline
\end{tabular}

Source: Elasticities for final products used for the calculation are from USDA/ERS, 2008a and Chouinard et al. 2010 (see Tables 6 and 7). 
F -3. Third 20\%Quintile of Income Marshallian Elasticities of Nine Target Sweetener-Intensive Foods

\begin{tabular}{|l|c|c|c|c|c|c|c|c|c|}
\hline Food & Milk & Cheese & $\begin{array}{c}\text { Ice } \\
\text { cream / } \\
\text { yogurt }\end{array}$ & $\begin{array}{c}\text { Breakfast } \\
\text { cereal / } \\
\text { Bakery }\end{array}$ & $\begin{array}{c}\text { Soft } \\
\text { drink }\end{array}$ & Juice & $\begin{array}{c}\text { Sweetener } \\
\text { products }\end{array}$ & $\begin{array}{c}\text { Processed } \\
\text { fruits and } \\
\text { vegetables }\end{array}$ & $\begin{array}{c}\text { Condiments } \\
\text { /Spices }\end{array}$ \\
\hline Milk & -0.75889 & -0.02796 & -0.00005 & -0.02944 & -0.07423 & 0.01790 & 0.00570 & -0.01436 & -0.00015 \\
\hline Cheese & -0.04344 & -1.10762 & -0.05023 & -0.03989 & -0.00143 & -0.01614 & 0.03765 & 0.01775 & -0.00114 \\
\hline $\begin{array}{l}\text { Ice cream / } \\
\text { yogurt }\end{array}$ & 0.00090 & -0.11882 & -0.86419 & -0.03621 & 0.00111 & -0.00485 & 0.00079 & 0.00018 & 0.00089 \\
\hline $\begin{array}{l}\text { Breakfast } \\
\text { cereal / } \\
\text { Bakery }\end{array}$ & -0.02124 & -0.01804 & -0.00742 & -0.50743 & -0.00150 & 0.00580 & 0.02156 & 0.02179 \\
\hline Soft drink & -0.06227 & 0.00009 & 0.00005 & 0.00020 & -0.96485 & -0.00312 & 0.00015 & -0.00120 \\
\hline Juice & 0.04036 & -0.02568 & -0.00397 & 0.01878 & -0.01135 & -0.90123 & 0.05074 & 0.01889 & -0.00199 \\
\hline $\begin{array}{l}\text { Sweetener } \\
\text { products }\end{array}$ & 0.00627 & 0.02833 & -0.00008 & 0.03661 & -0.00030 & 0.02478 & -0.51446 & 0.00508 & -0.00024 \\
\hline $\begin{array}{l}\text { Processed } \\
\text { fruits and } \\
\text { vegetables }\end{array}$ & -0.05058 & 0.03836 & -0.00079 & 0.10484 & -0.00309 & 0.02664 & 0.01321 & -2.02750 \\
\hline $\begin{array}{l}\text { Condiments / } \\
\text { Spices }\end{array}$ & -0.00062 & -0.00035 & -0.00020 & -0.00077 & -0.00077 & -0.00019 & -0.00055 & -0.00248 \\
\hline Source: Elastch & -0.00012 & -1.06283 \\
\hline
\end{tabular}

Source: Elasticities for final products used for the calculation are from USDA/ERS, 2008a and Chouinard et al. 2010 (see Tables 6 and 7). 
F -4. Fourth 20\%Quintile of Income Marshallian Elasticities of Nine Target Sweetener-Intensive Foods

\begin{tabular}{|c|c|c|c|c|c|c|c|c|c|}
\hline Food & Milk & Cheese & $\begin{array}{c}\text { Ice } \\
\text { cream / } \\
\text { yogurt }\end{array}$ & $\begin{array}{c}\text { Breakfast } \\
\text { cereal / } \\
\text { Bakery }\end{array}$ & $\begin{array}{c}\text { Soft } \\
\text { drink }\end{array}$ & Juice & $\begin{array}{c}\text { Sweetener } \\
\text { products }\end{array}$ & $\begin{array}{l}\text { Processed } \\
\text { fruits and } \\
\text { vegetables }\end{array}$ & $\begin{array}{c}\text { Condiments } \\
\text { / Spices }\end{array}$ \\
\hline Milk & -0.64715 & -0.02385 & -0.00005 & -0.02512 & -0.06333 & 0.01527 & 0.00484 & -0.01224 & -0.00015 \\
\hline Cheese & -0.03657 & -0.92853 & -0.04217 & -0.03358 & -0.00144 & -0.01353 & 0.03145 & 0.01490 & -0.00111 \\
\hline $\begin{array}{l}\text { Ice cream / } \\
\text { yogurt }\end{array}$ & 0.00088 & -0.09956 & -0.72435 & -0.03025 & 0.00112 & -0.00406 & 0.00075 & 0.00014 & 0.00087 \\
\hline $\begin{array}{l}\text { Breakfast } \\
\text { cereal / } \\
\text { Bakery }\end{array}$ & -0.01785 & -0.01509 & -0.00626 & -0.42271 & -0.00150 & 0.00482 & 0.01784 & 0.01816 & -0.00116 \\
\hline Soft drink & -0.05221 & 0.00009 & 0.00005 & 0.00019 & -0.80923 & -0.00261 & 0.00014 & 0.00002 & 0.00016 \\
\hline Juice & 0.03374 & -0.02175 & -0.00347 & 0.01559 & -0.00999 & -0.75947 & 0.04256 & 0.01594 & -0.00194 \\
\hline $\begin{array}{l}\text { Sweetener } \\
\text { products }\end{array}$ & 0.00543 & 0.02469 & -0.00008 & 0.03188 & -0.00032 & 0.02160 & -0.44849 & 0.00443 & -0.00024 \\
\hline $\begin{array}{l}\text { Processed } \\
\text { fruits and } \\
\text { vegetables }\end{array}$ & -0.07235 & 0.05605 & -0.00069 & 0.15243 & -0.00302 & 0.03866 & 0.02005 & -2.93468 & -0.00231 \\
\hline $\begin{array}{l}\text { Condiments / } \\
\text { Spices }\end{array}$ & -0.00078 & -0.00043 & -0.00020 & -0.00107 & -0.00086 & -0.00029 & -0.00064 & -0.00019 & -1.75701 \\
\hline
\end{tabular}

Source: Elasticities for final products used for the calculation are from USDA/ERS, 2008a and Chouinard et al. 2010 (see Tables 6 and 7). 
F -5. Highest 20\% Quintile of Income Marshallian Elasticities of Nine Target Sweetener-Intensive Foods

\begin{tabular}{|l|c|c|c|c|c|c|c|c|c|}
\hline Food & Milk & Cheese & $\begin{array}{c}\text { Ice } \\
\text { cream / } \\
\text { yogurt }\end{array}$ & $\begin{array}{c}\text { Breakfast } \\
\text { cereal / } \\
\text { Bakery }\end{array}$ & $\begin{array}{c}\text { Soft } \\
\text { drink }\end{array}$ & Juice & $\begin{array}{c}\text { Sweetener } \\
\text { products }\end{array}$ & $\begin{array}{c}\text { Processed } \\
\text { fruits and } \\
\text { vegetables }\end{array}$ & $\begin{array}{c}\text { Condiments } \\
\text { / Spices }\end{array}$ \\
\hline Milk & -0.57407 & -0.02116 & -0.00006 & -0.02229 & -0.05622 & 0.01355 & 0.00427 & -0.01085 & -0.00015 \\
\hline Cheese & -0.02835 & -0.71751 & -0.03271 & -0.02598 & -0.00140 & -0.01040 & 0.02414 & 0.01159 & -0.00098 \\
\hline $\begin{array}{l}\text { Ice cream / } \\
\text { yogurt }\end{array}$ & 0.00074 & -0.07690 & -0.55962 & -0.02335 & 0.00109 & -0.00318 & 0.00070 & 0.00004 & 0.00077 \\
\hline $\begin{array}{l}\text { Breakfast } \\
\text { cereal / } \\
\text { Bakery }\end{array}$ & -0.01420 & -0.01196 & -0.00507 & -0.33395 & -0.00149 & 0.00386 & 0.01392 & 0.01443 & -0.00104 \\
\hline Soft drink & -0.0422 & 0.00008 & 0.00006 & 0.00016 & -0.65425 & -0.00212 & 0.00014 & 0.00001 & 0.00015 \\
\hline Juice & 0.02642 & -0.01720 & -0.00295 & 0.01222 & -0.00839 & -0.59819 & 0.03324 & 0.01270 & -0.00175 \\
\hline $\begin{array}{l}\text { Sweetener } \\
\text { products }\end{array}$ & 0.00430 & 0.01964 & -0.00009 & 0.02537 & -0.00032 & 0.01721 & -0.35709 & 0.00355 & -0.00022 \\
\hline $\begin{array}{l}\text { Processed } \\
\text { fruits and } \\
\text { vegetables }\end{array}$ & -0.03599 & 0.02673 & -0.00097 & 0.07326 & -0.00329 & 0.01881 & 0.00869 & -1.42286 & -0.00231 \\
\hline $\begin{array}{l}\text { Condiments / } \\
\text { Spices }\end{array}$ & -0.00053 & -0.00028 & -0.00023 & -0.00059 & -0.00078 & -0.00010 & -0.00050 & -0.00003 & -0.70874 \\
\hline
\end{tabular}

Source: Elasticities for final products used for the calculation are from USDA/ERS, 2008a and Chouinard et al. 2010 (see Tables 6 and 7). 
Appendix G. Changes on All Households and Disaggregated Income Groups with Tax on the Price of Final Products for Nine Sweetener-Intensive Foods

\begin{tabular}{|c|c|c|c|c|c|c|c|c|c|c|c|c|}
\hline \multirow{4}{*}{ Food } & \multirow{2}{*}{\multicolumn{2}{|c|}{ All households }} & \multicolumn{10}{|c|}{ Households by quintiles } \\
\hline & & & \multicolumn{2}{|c|}{ Lowest 20\% } & \multicolumn{2}{|c|}{ Second $20 \%$} & \multicolumn{2}{|c|}{ Third 20\% } & \multicolumn{2}{|c|}{ Fourth 20\% } & \multicolumn{2}{|c|}{ Highest $20 \%$} \\
\hline & \multicolumn{12}{|c|}{ Food demand (per capita) } \\
\hline & $\begin{array}{c}\text { Initial } \\
\text { value } \\
\text { (dollars) }^{\mathrm{a}}\end{array}$ & $\begin{array}{c}\text { Change } \\
(\%)\end{array}$ & $\begin{array}{c}\text { Initial } \\
\text { value } \\
\text { (dollars) }^{\mathrm{a}}\end{array}$ & $\begin{array}{c}\text { Change } \\
\text { (\%) }\end{array}$ & $\begin{array}{c}\text { Initial } \\
\text { value } \\
\text { (dollars) }^{\mathrm{a}}\end{array}$ & $\begin{array}{c}\text { Change } \\
\text { (\%) }\end{array}$ & $\begin{array}{c}\text { Initial } \\
\text { value } \\
\text { (dollars) }^{\mathrm{a}}\end{array}$ & $\begin{array}{c}\text { Change } \\
(\%)\end{array}$ & $\begin{array}{c}\text { Initial } \\
\text { value } \\
\text { (dollars) }^{\mathrm{a}}\end{array}$ & $\begin{array}{c}\text { Change } \\
(\%)\end{array}$ & $\begin{array}{c}\text { Initial } \\
\text { value } \\
\text { (dollars) }^{\mathrm{a}}\end{array}$ & $\begin{array}{c}\text { Change } \\
(\%)\end{array}$ \\
\hline Milk & 100.44 & 0.214 & 104.98 & 0.301 & 107.31 & 0.227 & 95.18 & 0.224 & 99.59 & 0.191 & 98.18 & 0.168 \\
\hline Cheese & 65.55 & 1.431 & 60.44 & 2.285 & 56.54 & 1.879 & 62.73 & 1.484 & 66.77 & 1.239 & 75.57 & 0.951 \\
\hline $\begin{array}{l}\text { Ice cream / } \\
\text { yogurt }\end{array}$ & 27.39 & 0.027 & 25.26 & 0.029 & 23.62 & 0.028 & 26.21 & 0.028 & 27.90 & 0.027 & 31.58 & 0.026 \\
\hline $\begin{array}{l}\text { Breakfast } \\
\text { cereal / } \\
\text { Bakery }\end{array}$ & 149.78 & 0.796 & 150.03 & 1.178 & 141.06 & 0.962 & 138.98 & 0.852 & 148.90 & 0.705 & 164.84 & 0.550 \\
\hline Soft drink & 118.41 & 0.005 & 114.12 & 0.005 & 109.23 & 0.005 & 112.87 & 0.005 & 120.07 & 0.005 & 129.86 & 0.005 \\
\hline Juice & 42.96 & 1.893 & 41.98 & 2.858 & 40.55 & 2.275 & 40.33 & 2.001 & 42.70 & 1.679 & 47.40 & 1.311 \\
\hline $\begin{array}{l}\text { Sweetener } \\
\text { products }\end{array}$ & 87.56 & -19.820 & 86.58 & -29.277 & 79.50 & -24.616 & 85.20 & -20.215 & 87.20 & -17.623 & 95.78 & -14.032 \\
\hline $\begin{array}{l}\text { Processed } \\
\text { fruits and } \\
\text { vegetables }\end{array}$ & 29.39 & 0.498 & 28.84 & 0.779 & 27.74 & 0.613 & 28.36 & 0.513 & 29.48 & 0.431 & 31.53 & 0.337 \\
\hline $\begin{array}{l}\text { Condiments } \\
\text { / Spices }\end{array}$ & 104.65 & -0.019 & 90.40 & -0.022 & 93.45 & -0.020 & 101.54 & -0.020 & 108.64 & -0.019 & 118.83 & -0.018 \\
\hline \multirow[b]{2}{*}{ Sweeteners } & \multicolumn{12}{|c|}{ Sweeteners consumption quantities (per capita) } \\
\hline & $\begin{array}{c}\text { Initial } \\
\text { value } \\
\text { (lbs) } \\
\end{array}$ & $\begin{array}{c}\text { Change } \\
(\%)\end{array}$ & $\begin{array}{c}\text { Initial } \\
\text { value } \\
\text { (lbs) } \\
\end{array}$ & $\begin{array}{c}\text { Change } \\
(\%)\end{array}$ & $\begin{array}{c}\text { Initial } \\
\text { value } \\
\text { (lbs) }\end{array}$ & $\begin{array}{c}\text { Change } \\
(\%)\end{array}$ & $\begin{array}{c}\text { Initial } \\
\text { value } \\
\text { (lbs) }\end{array}$ & $\begin{array}{c}\text { Change } \\
(\%)\end{array}$ & $\begin{array}{c}\text { Initial } \\
\text { value } \\
\text { (lbs) }\end{array}$ & $\begin{array}{c}\text { Change } \\
(\%)\end{array}$ & $\begin{array}{c}\text { Initial } \\
\text { value } \\
\text { (lbs) }\end{array}$ & $\begin{array}{c}\text { Change } \\
(\%)\end{array}$ \\
\hline $\begin{array}{l}\text { All } \\
\text { Sweeteners } \\
\text { (sugar } \\
\text { equivalent) }\end{array}$ & 105.69 & -10.000 & 103.83 & -13.102 & 97.85 & -10.734 & 101.28 & -9.128 & 105.85 & -7.794 & 115.37 & -6.256 \\
\hline
\end{tabular}




\begin{tabular}{|c|c|c|c|c|c|c|c|c|c|c|c|c|}
\hline Sugars & 61.90 & -13.390 & 61.21 & -19.775 & 56.96 & -16.408 & 59.54 & -13.816 & 61.73 & -11.892 & 67.67 & -9.488 \\
\hline $\begin{array}{l}\text { Corn } \\
\text { Sweeteners }\end{array}$ & 54.81 & -2.270 & 53.41 & -3.400 & 51.24 & -2.737 & 52.26 & -2.363 & 55.22 & -1.996 & 59.63 & -1.618 \\
\hline $\begin{array}{l}\text { Other } \\
\text { Sweeteners }\end{array}$ & 2.86 & -1.083 & 2.72 & -1.652 & 2.63 & -1.321 & 2.71 & -1.132 & 2.89 & -0.950 & 3.17 & -0.761 \\
\hline $\begin{array}{l}\text { Artificial } \\
\text { Sweeteners }\end{array}$ & 0.54 & -13.139 & 0.53 & -19.621 & 0.49 & -16.232 & 0.52 & -13.507 & 0.54 & -11.615 & 0.59 & -9.274 \\
\hline
\end{tabular}

Source: Elasticities for final products are from USDA/ERS, 2008a and Chouinard et al. 2010 (see Tables 6 and 7).

a. Initial prices are normalized to $\$ 1 /$ unit.

b. See Table 10, footnote b. 
Appendix H. Changes on All Households and Disaggregated Income Groups with Tax on the Price of Caloric Sweeteners for Nine Sweetener-Intensive Foods

\begin{tabular}{|c|c|c|c|c|c|c|c|c|c|c|c|c|}
\hline \multirow[b]{4}{*}{ Food } & \multirow{2}{*}{\multicolumn{2}{|c|}{ All households }} & \multicolumn{10}{|c|}{ Households by quintiles } \\
\hline & & & \multicolumn{2}{|c|}{ Lowest 20\% } & \multicolumn{2}{|c|}{ Second $20 \%$} & \multicolumn{2}{|c|}{ Third 20\% } & \multicolumn{2}{|c|}{ Fourth $20 \%$} & \multicolumn{2}{|c|}{ Highest 20\% } \\
\hline & \multicolumn{12}{|c|}{ Food demand (per capita) } \\
\hline & $\begin{array}{c}\text { Initial } \\
\text { value } \\
\text { (dollars) }^{\mathrm{a}}\end{array}$ & $\begin{array}{c}\text { Change } \\
\text { (\%) }\end{array}$ & $\begin{array}{c}\text { Initial } \\
\text { value } \\
\text { (dollars) }^{\mathrm{a}}\end{array}$ & $\begin{array}{c}\text { Change } \\
\text { (\%) }\end{array}$ & $\begin{array}{c}\text { Initial } \\
\text { value } \\
\text { (dollars) } \\
\text { a }\end{array}$ & $\begin{array}{c}\text { Change } \\
(\%)\end{array}$ & $\begin{array}{c}\text { Initial } \\
\text { value } \\
\text { (dollars) } \\
\text { a }\end{array}$ & $\begin{array}{c}\text { Change } \\
\text { (\%) }\end{array}$ & $\begin{array}{c}\text { Initial } \\
\text { value } \\
\text { (dollars) }^{\mathrm{a}}\end{array}$ & $\begin{array}{c}\text { Change } \\
(\%)\end{array}$ & $\begin{array}{c}\text { Initial } \\
\text { value } \\
\text { (dollars) }^{\mathrm{a}}\end{array}$ & $\begin{array}{c}\text { Change } \\
(\%)\end{array}$ \\
\hline Milk & 100.44 & -0.369 & 104.98 & -0.516 & 107.31 & -0.390 & 95.18 & -0.387 & 99.59 & -0.330 & 98.18 & -0.293 \\
\hline Cheese & 65.55 & -0.002 & 60.44 & 0.000 & 56.54 & -0.001 & 62.73 & -0.002 & 66.77 & -0.002 & 75.57 & -0.003 \\
\hline $\begin{array}{l}\text { Ice cream / } \\
\text { yogurt }\end{array}$ & 27.39 & -0.560 & 25.26 & -0.889 & 23.62 & -0.733 & 26.21 & -0.580 & 27.90 & -0.486 & 31.58 & -0.375 \\
\hline $\begin{array}{l}\text { Breakfast } \\
\text { cereal / } \\
\text { Bakery }\end{array}$ & 149.78 & -0.232 & 150.03 & -0.336 & 141.06 & -0.277 & 138.98 & -0.248 & 148.90 & -0.208 & 164.84 & -0.165 \\
\hline Soft drink & 118.41 & -1.182 & 114.12 & -1.791 & 109.23 & -1.445 & 112.87 & -1.230 & 120.07 & -1.032 & 129.86 & -0.834 \\
\hline Juice & 42.96 & -0.103 & 41.98 & -0.150 & 40.55 & -0.121 & 40.33 & -0.109 & 42.70 & -0.093 & 47.40 & -0.075 \\
\hline $\begin{array}{l}\text { Sweetener } \\
\text { products }\end{array}$ & 87.56 & -1.498 & 86.58 & -2.212 & 79.50 & -1.860 & 85.20 & -1.528 & 87.20 & -1.332 & 95.78 & -1.061 \\
\hline $\begin{array}{l}\text { Processed } \\
\text { fruits and } \\
\text { vegetables }\end{array}$ & 29.39 & -0.580 & 28.84 & -0.856 & 27.74 & -0.690 & 28.36 & -0.596 & 29.48 & -0.513 & 31.53 & -0.422 \\
\hline $\begin{array}{l}\text { Condiments } \\
\text { / Spices }\end{array}$ & 104.65 & -0.150 & 90.40 & -0.251 & 93.45 & -0.188 & 101.54 & -0.153 & 108.64 & -0.128 & 118.83 & -0.103 \\
\hline \multirow[b]{2}{*}{ Sweeteners } & \multicolumn{12}{|c|}{ Sweeteners consumption quantities (per capita) } \\
\hline & $\begin{array}{c}\text { Initial } \\
\text { value } \\
\text { (lbs) } \\
\end{array}$ & $\begin{array}{c}\text { Change } \\
(\%)\end{array}$ & $\begin{array}{c}\text { Initial } \\
\text { value } \\
\text { (lbs) } \\
\end{array}$ & $\begin{array}{c}\text { Change } \\
\text { (\%) }\end{array}$ & $\begin{array}{c}\text { Initial } \\
\text { value } \\
\text { (lbs) } \\
\end{array}$ & $\begin{array}{c}\text { Change } \\
(\%)\end{array}$ & $\begin{array}{c}\text { Initial } \\
\text { value } \\
\text { (lbs) } \\
\end{array}$ & $\begin{array}{c}\text { Change } \\
(\%)\end{array}$ & $\begin{array}{c}\text { Initial } \\
\text { value } \\
\text { (lbs) } \\
\end{array}$ & $\begin{array}{c}\text { Change } \\
(\%)\end{array}$ & $\begin{array}{c}\text { Initial } \\
\text { value } \\
\text { (lbs) } \\
\end{array}$ & $\begin{array}{c}\text { Change } \\
(\%)\end{array}$ \\
\hline $\begin{array}{l}\text { All } \\
\text { Sweeteners } \\
\text { (sugar } \\
\text { equivalent) }\end{array}$ & 105.69 & -10.000 & 103.83 & -10.451 & 97.85 & -10.193 & 101.28 & -10.039 & 105.85 & -9.899 & 115.37 & -9.727 \\
\hline
\end{tabular}




\begin{tabular}{|c|c|c|c|c|c|c|c|c|c|c|c|c|}
\hline Sugars & 61.90 & -8.954 & 61.21 & -9.460 & 56.96 & -9.141 & 59.54 & -9.006 & 61.73 & -8.829 & 67.67 & -8.668 \\
\hline $\begin{array}{l}\text { Corn } \\
\text { Sweeteners }\end{array}$ & 54.81 & -12.412 & 53.41 & -12.798 & 51.24 & -12.580 & 52.26 & -12.443 & 55.22 & -12.331 & 59.63 & -12.174 \\
\hline $\begin{array}{l}\text { Other } \\
\text { Sweeteners }\end{array}$ & 2.86 & 3.221 & 2.72 & 3.066 & 2.63 & 3.122 & 2.71 & 3.210 & 2.89 & 3.257 & 3.17 & 3.326 \\
\hline $\begin{array}{l}\text { Artificial } \\
\text { Sweeteners }\end{array}$ & 0.54 & 1.322 & 0.53 & 0.682 & 0.49 & 1.057 & 0.52 & 1.241 & 0.54 & 1.482 & 0.59 & 1.703 \\
\hline \multicolumn{13}{|c|}{ Sweeteners consumption values (per capita) } \\
\hline Sweeteners & $\begin{array}{c}\text { Initial } \\
\text { value } \\
\text { (dollars) }\end{array}$ & $\begin{array}{c}\text { Change } \\
\text { (\%) }\end{array}$ & $\begin{array}{c}\text { Initial } \\
\text { value } \\
\text { (dollars) }\end{array}$ & $\begin{array}{c}\text { Change } \\
\text { (\%) }\end{array}$ & $\begin{array}{c}\text { Initial } \\
\text { value } \\
\text { (dollars) }\end{array}$ & $\begin{array}{c}\text { Change } \\
\text { (\%) }\end{array}$ & $\begin{array}{c}\text { Initial } \\
\text { value } \\
\text { (dollars) }\end{array}$ & $\begin{array}{c}\text { Change } \\
\text { (\%) }\end{array}$ & $\begin{array}{c}\text { Initial } \\
\text { value } \\
\text { (dollars) }\end{array}$ & $\begin{array}{c}\text { Change } \\
(\%)\end{array}$ & $\begin{array}{c}\text { Initial } \\
\text { value } \\
\text { (dollars) }\end{array}$ & $\begin{array}{c}\text { Change } \\
\text { (\%) }\end{array}$ \\
\hline $\begin{array}{l}\text { All } \\
\text { Sweeteners }\end{array}$ & 22.66 & 20.133 & 22.26 & 19.520 & 20.95 & 19.952 & 21.72 & 20.054 & 22.68 & 20.292 & 24.75 & 20.456 \\
\hline Sugars & 13.8 & 17.498 & 13.64 & 16.842 & 12.70 & 17.270 & 13.27 & 17.424 & 13.76 & 17.662 & 15.08 & 17.862 \\
\hline $\begin{array}{l}\text { Corn } \\
\text { Sweeteners }\end{array}$ & 7.31 & 28.823 & 7.12 & 28.266 & 6.84 & 28.579 & 6.97 & 28.776 & 7.37 & 28.935 & 7.95 & 29.173 \\
\hline $\begin{array}{l}\text { Other } \\
\text { Sweeteners }\end{array}$ & 0.94 & 3.346 & 0.89 & 3.193 & 0.87 & 3.247 & 0.89 & 3.336 & 0.95 & 3.381 & 1.04 & 3.450 \\
\hline $\begin{array}{l}\text { Artificial } \\
\text { Sweeteners }\end{array}$ & 0.61 & 1.322 & 0.59 & 0.682 & 0.55 & 1.057 & 0.58 & 1.241 & 0.61 & 1.482 & 0.66 & 1.703 \\
\hline
\end{tabular}

Source: Elasticities for final products are from USDA/ERS, 2008a and Chouinard et al. 2010 (see Tables 6 and 7).

a. Initial prices are normalized to \$1/unit.

b. See Table 10, footnote b. 
Appendix I. Changes on All Households and Disaggregated Income Groups with Tax on the Price of Sugars for Nine SweetenerIntensive Foods

\begin{tabular}{|c|c|c|c|c|c|c|c|c|c|c|c|c|}
\hline \multirow{4}{*}{ Food } & \multirow{2}{*}{\multicolumn{2}{|c|}{ All households }} & \multicolumn{10}{|c|}{ Households by quintiles } \\
\hline & & & \multicolumn{2}{|c|}{ Lowest 20\% } & \multicolumn{2}{|c|}{ Second $20 \%$} & \multicolumn{2}{|c|}{ Third $20 \%$} & \multicolumn{2}{|c|}{ Fourth 20\% } & \multicolumn{2}{|c|}{ Highest 20\% } \\
\hline & \multicolumn{12}{|c|}{ Food demand (per capita) } \\
\hline & $\begin{array}{c}\text { Initial } \\
\text { value } \\
\text { (dollars) }^{\mathrm{a}}\end{array}$ & $\begin{array}{c}\text { Change } \\
(\%)\end{array}$ & $\begin{array}{c}\text { Initial } \\
\text { value } \\
\text { (dollars) }^{\mathrm{a}}\end{array}$ & $\begin{array}{c}\text { Change } \\
(\%)\end{array}$ & $\begin{array}{c}\text { Initial } \\
\text { value } \\
\text { (dollars) }^{\mathrm{a}}\end{array}$ & $\begin{array}{c}\text { Change } \\
(\%)\end{array}$ & $\begin{array}{c}\text { Initial } \\
\text { value } \\
\text { (dollars) }^{\mathrm{a}}\end{array}$ & $\begin{array}{c}\text { Change } \\
(\%)\end{array}$ & $\begin{array}{c}\text { Initial } \\
\text { value } \\
\text { (dollars) }^{\mathrm{a}}\end{array}$ & $\begin{array}{c}\text { Change } \\
(\%)\end{array}$ & $\begin{array}{c}\text { Initial } \\
\text { value } \\
\text { (dollars) }^{\mathrm{a}}\end{array}$ & $\begin{array}{c}\text { Change } \\
(\%)\end{array}$ \\
\hline Milk & 100.44 & -0.182 & 104.98 & -0.254 & 107.31 & -0.192 & 95.18 & -0.191 & 99.59 & -0.163 & 98.18 & -0.144 \\
\hline Cheese & 65.55 & 0.101 & 60.44 & 0.163 & 56.54 & 0.133 & 62.73 & 0.105 & 66.77 & 0.087 & 75.57 & 0.066 \\
\hline $\begin{array}{l}\text { Ice cream / } \\
\text { yogurt }\end{array}$ & 27.39 & -0.488 & 25.26 & -0.775 & 23.62 & -0.638 & 26.21 & -0.506 & 27.90 & -0.423 & 31.58 & -0.326 \\
\hline $\begin{array}{l}\text { Breakfast } \\
\text { cereal / } \\
\text { Bakery }\end{array}$ & 149.78 & -0.330 & 150.03 & -0.478 & 141.06 & -0.394 & 138.98 & -0.353 & 148.90 & -0.294 & 164.84 & -0.234 \\
\hline Soft drink & 118.41 & -0.092 & 114.12 & -0.139 & 109.23 & -0.112 & 112.87 & -0.095 & 120.07 & -0.080 & 129.86 & -0.064 \\
\hline Juice & 42.96 & 0.189 & 41.98 & 0.288 & 40.55 & 0.228 & 40.33 & 0.200 & 42.70 & 0.167 & 47.40 & 0.130 \\
\hline $\begin{array}{l}\text { Sweetener } \\
\text { products }\end{array}$ & 87.56 & -2.633 & 86.58 & -3.888 & 79.50 & -3.270 & 85.20 & -2.685 & 87.20 & -2.341 & 95.78 & -1.864 \\
\hline $\begin{array}{l}\text { Processed } \\
\text { fruits and } \\
\text { vegetables }\end{array}$ & 29.39 & -0.061 & 28.84 & -0.084 & 27.74 & -0.070 & 28.36 & -0.063 & 29.48 & -0.056 & 31.53 & -0.048 \\
\hline $\begin{array}{l}\text { Condiments } \\
\text { / Spices }\end{array}$ & 104.65 & -0.142 & 90.40 & -0.239 & 93.45 & -0.179 & 101.54 & -0.146 & 108.64 & -0.122 & 118.83 & -0.098 \\
\hline \multirow[b]{2}{*}{ Sweeteners } & \multicolumn{12}{|c|}{ Sweeteners consumption quantities (per capita) } \\
\hline & $\begin{array}{c}\text { Initial } \\
\text { value (lbs) }\end{array}$ & $\begin{array}{c}\text { Change } \\
\text { (\%) }\end{array}$ & $\begin{array}{c}\text { Initial } \\
\text { value (lbs) }\end{array}$ & $\begin{array}{c}\text { Change } \\
(\%)\end{array}$ & $\begin{array}{c}\text { Initial } \\
\text { value } \\
\text { (lbs) }\end{array}$ & $\begin{array}{c}\text { Change } \\
(\%)\end{array}$ & $\begin{array}{c}\text { Initial } \\
\text { value } \\
\text { (lbs) }\end{array}$ & $\begin{array}{c}\text { Change } \\
(\%)\end{array}$ & $\begin{array}{c}\text { Initial } \\
\text { value } \\
\text { (lbs) }\end{array}$ & $\begin{array}{c}\text { Change } \\
(\%)\end{array}$ & $\begin{array}{c}\text { Initial } \\
\text { value } \\
\text { (lbs) }\end{array}$ & $\begin{array}{c}\text { Change } \\
(\%)\end{array}$ \\
\hline $\begin{array}{l}\text { All } \\
\text { Sweeteners } \\
\text { (sugar }\end{array}$ & 105.69 & -10.000 & 103.83 & -10.613 & 97.85 & -10.132 & 101.28 & -10.098 & 105.85 & -9.821 & 115.37 & -9.707 \\
\hline
\end{tabular}




\begin{tabular}{|c|c|c|c|c|c|c|c|c|c|c|c|c|}
\hline \multicolumn{13}{|l|}{ equivalent) $^{\mathrm{b}}$} \\
\hline Sugars & 61.90 & -22.089 & 61.21 & -22.804 & 56.96 & -22.426 & 59.54 & -22.139 & 61.73 & -21.921 & 67.67 & -21.652 \\
\hline $\begin{array}{l}\text { Corn } \\
\text { Sweeteners }\end{array}$ & 54.81 & 7.405 & 53.41 & 7.207 & 51.24 & 7.302 & 52.26 & 7.389 & 55.22 & 7.418 & 59.63 & 7.559 \\
\hline $\begin{array}{l}\text { Artificial } \\
\text { Sweeteners }\end{array}$ & 0.54 & 0.203 & 0.53 & -0.676 & 0.49 & -0.193 & 0.52 & 0.109 & 0.54 & 0.407 & 0.59 & 0.745 \\
\hline \multirow[b]{2}{*}{ Sweeteners } & \multicolumn{12}{|c|}{ Sweeteners consumption values (per capita) } \\
\hline & $\begin{array}{c}\text { Initial } \\
\text { value } \\
\text { (dollars) }\end{array}$ & $\begin{array}{c}\text { Change } \\
\text { (\%) }\end{array}$ & $\begin{array}{c}\text { Initial } \\
\text { value } \\
\text { (dollars) }\end{array}$ & $\begin{array}{c}\text { Change } \\
(\%)\end{array}$ & $\begin{array}{c}\text { Initial } \\
\text { value } \\
\text { (dollars) }\end{array}$ & $\begin{array}{c}\text { Change } \\
\text { (\%) }\end{array}$ & $\begin{array}{c}\text { Initial } \\
\text { value } \\
\text { (dollars) }\end{array}$ & $\begin{array}{c}\text { Change } \\
\text { (\%) }\end{array}$ & $\begin{array}{c}\text { Initial } \\
\text { value } \\
\text { (dollars) }\end{array}$ & $\begin{array}{c}\text { Change } \\
\text { (\%) }\end{array}$ & $\begin{array}{c}\text { Initial } \\
\text { value } \\
\text { (dollars) }\end{array}$ & $\begin{array}{c}\text { Change } \\
\text { (\%) }\end{array}$ \\
\hline $\begin{array}{l}\text { All } \\
\text { Sweeteners }\end{array}$ & 22.66 & 20.312 & 22.26 & 19.590 & 20.95 & 19.869 & 21.72 & 20.293 & 22.68 & 20.434 & 24.75 & 20.828 \\
\hline Sugars & 13.8 & 29.226 & 13.64 & 28.042 & 12.70 & 28.677 & 13.27 & 29.137 & 13.76 & 29.505 & 15.08 & 29.950 \\
\hline $\begin{array}{l}\text { Corn } \\
\text { Sweeteners }\end{array}$ & 7.31 & 7.405 & 7.12 & 7.207 & 6.84 & 7.302 & 6.97 & 7.389 & 7.37 & 7.418 & 7.95 & 7.559 \\
\hline $\begin{array}{l}\text { Other } \\
\text { Sweeteners }\end{array}$ & 0.94 & 2.809 & 0.89 & 2.709 & 0.87 & 2.719 & 0.89 & 2.798 & 0.95 & 2.816 & 1.04 & 2.906 \\
\hline $\begin{array}{l}\text { Artificial } \\
\text { Sweeteners }\end{array}$ & 0.61 & 0.203 & 0.59 & -0.676 & 0.55 & -0.193 & 0.58 & 0.109 & 0.61 & 0.407 & 0.66 & 0.745 \\
\hline
\end{tabular}

Source: Elasticities for final products are from USDA/ERS, 2008a and Chouinard et al. 2010 (see Tables 6 and 7).

a. Initial prices are normalized to $\$ 1 /$ unit.

b. See Table 10, footnote b. 
Appendix J. Changes on All Households and Disaggregated Income Groups with Tax on the Price of Corn Sweeteners for Nine Sweetener-Intensive Foods

\begin{tabular}{|c|c|c|c|c|c|c|c|c|c|c|c|c|}
\hline \multirow{4}{*}{ Food } & \multirow{2}{*}{\multicolumn{2}{|c|}{ All households }} & \multicolumn{10}{|c|}{ Food demand by household quintiles } \\
\hline & & & \multicolumn{2}{|c|}{ Lowest 20\% } & \multicolumn{2}{|c|}{ Second $20 \%$} & \multicolumn{2}{|c|}{ Third 20\% } & \multicolumn{2}{|c|}{ Fourth 20\% } & \multicolumn{2}{|c|}{ Highest $20 \%$} \\
\hline & \multicolumn{12}{|c|}{ Food demand (per capita) } \\
\hline & $\begin{array}{c}\text { Initial } \\
\text { value } \\
\text { (dollars) }^{\mathrm{a}}\end{array}$ & $\begin{array}{c}\text { Change } \\
\text { (\%) }\end{array}$ & $\begin{array}{c}\text { Initial } \\
\text { value } \\
\text { (dollars) }^{\mathrm{a}}\end{array}$ & $\begin{array}{c}\text { Change } \\
(\%)\end{array}$ & $\begin{array}{c}\text { Initial } \\
\text { value } \\
\text { (dollars) }^{\mathrm{a}}\end{array}$ & $\begin{array}{c}\text { Change } \\
\text { (\%) }\end{array}$ & $\begin{array}{c}\text { Initial } \\
\text { value } \\
\text { (dollars) }^{\mathrm{a}}\end{array}$ & $\begin{array}{c}\text { Change } \\
(\%)\end{array}$ & $\begin{array}{c}\text { Initial } \\
\text { value } \\
\text { (dollars) }^{\mathrm{a}}\end{array}$ & $\begin{array}{c}\text { Change } \\
\text { (\%) }\end{array}$ & $\begin{array}{c}\text { Initial } \\
\text { value } \\
\text { (dollars) }^{\mathrm{a}}\end{array}$ & $\begin{array}{c}\text { Change } \\
\text { (\%) }\end{array}$ \\
\hline Milk & 100.44 & -0.733 & 104.98 & -1.025 & 107.31 & -0.774 & 95.18 & -0.768 & 99.59 & -0.655 & 98.18 & -0.581 \\
\hline Cheese & 65.55 & -0.138 & 60.44 & -0.215 & 56.54 & -0.179 & 62.73 & -0.143 & 66.77 & -0.121 & 75.57 & -0.095 \\
\hline $\begin{array}{l}\text { Ice cream / } \\
\text { yogurt }\end{array}$ & 27.39 & -0.825 & 25.26 & -1.310 & 23.62 & -1.079 & 26.21 & -0.855 & 27.90 & -0.716 & 31.58 & -0.552 \\
\hline $\begin{array}{l}\text { Breakfast } \\
\text { cereal / } \\
\text { Bakery }\end{array}$ & 149.78 & -0.171 & 150.03 & -0.245 & 141.06 & -0.203 & 138.98 & -0.182 & 148.90 & -0.153 & 164.84 & -0.122 \\
\hline Soft drink & 118.41 & -3.025 & 114.12 & -4.585 & 109.23 & -3.698 & 112.87 & -3.149 & 120.07 & -2.641 & 129.86 & -2.135 \\
\hline Juice & 42.96 & -0.525 & 41.98 & -0.778 & 40.55 & -0.624 & 40.33 & -0.554 & 42.70 & -0.469 & 47.40 & -0.372 \\
\hline $\begin{array}{l}\text { Sweetener } \\
\text { products }\end{array}$ & 87.56 & -0.458 & 86.58 & -0.675 & 79.50 & -0.568 & 85.20 & -0.467 & 87.20 & -0.407 & 95.78 & -0.324 \\
\hline $\begin{array}{l}\text { Processed } \\
\text { fruits and } \\
\text { vegetables }\end{array}$ & 29.39 & -1.450 & 28.84 & -2.150 & 27.74 & -1.729 & 28.36 & -1.490 & 29.48 & -1.282 & 31.53 & -1.051 \\
\hline $\begin{array}{l}\text { Condiments } \\
\text { / Spices }\end{array}$ & 104.65 & -0.204 & 90.40 & -0.343 & 93.45 & -0.257 & 101.54 & -0.209 & 108.64 & -0.175 & 118.83 & -0.140 \\
\hline \multirow[b]{2}{*}{ Sweeteners } & \multicolumn{12}{|c|}{ Sweeteners consumption quantities (per capita) } \\
\hline & $\begin{array}{c}\text { Initial } \\
\text { value } \\
\text { (lbs) } \\
\end{array}$ & $\begin{array}{c}\text { Change } \\
\text { (\%) }\end{array}$ & $\begin{array}{l}\text { Initial } \\
\text { value } \\
\text { (lbs) } \\
\end{array}$ & $\begin{array}{c}\text { Change } \\
(\%)\end{array}$ & $\begin{array}{c}\text { Initial } \\
\text { value } \\
\text { (lbs) }\end{array}$ & $\begin{array}{c}\text { Change } \\
(\%)\end{array}$ & $\begin{array}{c}\text { Initial } \\
\text { value } \\
\text { (lbs) }\end{array}$ & $\begin{array}{c}\text { Change } \\
(\%)\end{array}$ & $\begin{array}{c}\text { Initial } \\
\text { value } \\
\text { (lbs) } \\
\end{array}$ & $\begin{array}{c}\text { Change } \\
(\%)\end{array}$ & $\begin{array}{c}\text { Initial } \\
\text { value } \\
\text { (lbs) } \\
\end{array}$ & $\begin{array}{c}\text { Change } \\
(\%)\end{array}$ \\
\hline $\begin{array}{l}\text { All } \\
\text { Sweeteners } \\
\text { (sugar } \\
\text { equivalent) }^{\text {b }}\end{array}$ & 105.69 & -10.000 & 103.83 & -10.273 & 97.85 & -10.250 & 101.28 & -9.979 & 105.85 & -9.993 & 115.37 & -9.744 \\
\hline
\end{tabular}




\begin{tabular}{|c|c|c|c|c|c|c|c|c|c|c|c|c|}
\hline Sugars & 61.90 & 7.727 & 61.21 & 7.428 & 56.96 & 7.767 & 59.54 & 7.645 & 61.73 & 7.821 & 67.67 & 7.830 \\
\hline $\begin{array}{l}\text { Corn } \\
\text { Sweeteners }\end{array}$ & 54.81 & -37.636 & 53.41 & -38.236 & 51.24 & -37.884 & 52.26 & -37.686 & 55.22 & -37.491 & 59.63 & -37.290 \\
\hline $\begin{array}{l}\text { Other } \\
\text { Sweeteners }\end{array}$ & 2.86 & 4.729 & 2.72 & 4.394 & 2.63 & 4.564 & 2.71 & 4.710 & 2.89 & 4.829 & 3.17 & 4.909 \\
\hline $\begin{array}{l}\text { Artificial } \\
\text { Sweeteners }\end{array}$ & 0.54 & 3.117 & 0.53 & 2.554 & 0.49 & 2.923 & 0.52 & 3.028 & 0.54 & 3.280 & 0.59 & 3.426 \\
\hline \multirow[b]{2}{*}{ Sweeteners } & \multicolumn{12}{|c|}{ Sweeteners consumption values (per capita) } \\
\hline & $\begin{array}{c}\text { Initial } \\
\text { value } \\
\text { (dollars) }\end{array}$ & $\begin{array}{c}\text { Change } \\
(\%)\end{array}$ & $\begin{array}{c}\text { Initial } \\
\text { value } \\
\text { (dollars) }\end{array}$ & $\begin{array}{c}\text { Change } \\
(\%)\end{array}$ & $\begin{array}{c}\text { Initial } \\
\text { value } \\
\text { (dollars) }\end{array}$ & $\begin{array}{c}\text { Change } \\
\text { (\%) }\end{array}$ & $\begin{array}{c}\text { Initial } \\
\text { value } \\
\text { (dollars) }\end{array}$ & $\begin{array}{c}\text { Change } \\
(\%)\end{array}$ & $\begin{array}{c}\text { Initial } \\
\text { value } \\
\text { (dollars) }\end{array}$ & $\begin{array}{c}\text { Change } \\
(\%)\end{array}$ & $\begin{array}{c}\text { Initial } \\
\text { value } \\
\text { (dollars) }\end{array}$ & $\begin{array}{c}\text { Change } \\
(\%)\end{array}$ \\
\hline $\begin{array}{l}\text { All } \\
\text { Sweeteners }\end{array}$ & 22.66 & 31.635 & 22.26 & 30.681 & 20.95 & 31.685 & 21.72 & 31.405 & 22.68 & 31.988 & 24.75 & 31.935 \\
\hline Sugars & 13.8 & 7.727 & 13.64 & 7.428 & 12.70 & 7.767 & 13.27 & 7.645 & 13.76 & 7.821 & 15.08 & 7.830 \\
\hline $\begin{array}{l}\text { Corn } \\
\text { Sweeteners }\end{array}$ & 7.31 & 82.578 & 7.12 & 80.848 & 6.84 & 81.875 & 6.97 & 82.433 & 7.37 & 82.993 & 7.95 & 83.577 \\
\hline $\begin{array}{l}\text { Other } \\
\text { Sweeteners }\end{array}$ & 0.94 & 4.729 & 0.89 & 4.394 & 0.87 & 4.564 & 0.89 & 4.710 & 0.95 & 4.829 & 1.04 & 4.909 \\
\hline $\begin{array}{l}\text { Artificial } \\
\text { Sweeteners }\end{array}$ & 0.61 & 3.117 & 0.59 & 2.554 & 0.55 & 2.923 & 0.58 & 3.028 & 0.61 & 3.280 & 0.66 & 3.426 \\
\hline
\end{tabular}

Source: Elasticities for final products are from USDA/ERS, 2008a and Chouinard et al. 2010 (see Tables 6 and 7).

a. Initial prices are normalized to $\$ 1 /$ unit.

b. See Table 10, footnote b. 
Appendix K. Changes for All Households with Tax for Nine Sweetener-Intensive Foods (Reduce the Sugar Equivalent Quantity of All Sweeteners by 20\%)

K-1. Changes for All Households with Tax on the Price of Final Products (Reduce the Sugar Equivalent Quantity of All Sweeteners by 20\%)

\begin{tabular}{|l|c|c|c|c|}
\hline Food & $\begin{array}{c}\text { Initial per } \\
\text { capita food } \\
\text { demand } \\
\text { (dollars) }\end{array}$ & $\begin{array}{c}\text { Tax rate } \\
\text { (\%) }\end{array}$ & $\begin{array}{c}\text { Price with } \\
\text { tax }\end{array}$ & $\begin{array}{c}\text { Food } \\
\text { demand } \\
\text { change } \\
\text { (\%) }\end{array}$ \\
\hline Milk & 100.44 & 0.000 & 1.000 & 0.429 \\
\hline Cheese & 65.55 & 0.000 & 1.000 & 2.870 \\
\hline Ice cream / yogurt & 27.39 & 0.000 & 1.000 & 0.048 \\
\hline $\begin{array}{l}\text { Breakfast cereal / } \\
\text { Bakery }\end{array}$ & 149.78 & 0.000 & 1.000 & 1.600 \\
\hline Soft drink & 118.41 & 0.000 & 1.000 & 0.009 \\
\hline Juice & 42.96 & 0.000 & 1.000 & 3.799 \\
\hline Sweetener products & 87.56 & 78.602 & 1.786 & -39.645 \\
\hline $\begin{array}{l}\text { Processed fruits and } \\
\text { vegetables }\end{array}$ & 29.39 & 0.002 & 1.000 & 1.039 \\
\hline Condiments / Spices & 104.65 & 0.000 & 1.000 & -0.034 \\
\hline Sweeteners & Initial per capita sweeteners & Sweeteners consumption \\
quantity change (\%)
\end{tabular}

Source: Elasticities for final products are from USDA/ERS, 2008a and Chouinard et al. 2010 (see Tables 6 and 7).

a. Initial prices are normalized to \$1/unit.

b. See Table 10, footnote b. 
K-2. Changes for All Households with Tax on the Price of Caloric Sweeteners (Reduce the Sugar Equivalent Quantity of All Sweeteners by $20 \%$ )

\begin{tabular}{|c|c|c|c|c|c|c|c|c|}
\hline \multirow{5}{*}{ Food } & \multirow{5}{*}{$\begin{array}{l}\text { Initial per } \\
\text { capita food } \\
\text { demand } \\
\text { (dollars) }^{\mathrm{a}}\end{array}$} & \multirow{5}{*}{$\begin{array}{l}\text { Price with } \\
\quad \text { tax }\end{array}$} & \multirow{5}{*}{$\begin{array}{c}\text { Food } \\
\text { demand } \\
\text { change } \\
(\%)\end{array}$} & \multicolumn{5}{|c|}{ Tax rate } \\
\hline & & & & Sugars & $\begin{array}{c}\text { Corn } \\
\text { Sweeteners }\end{array}$ & $\begin{array}{c}\text { Other } \\
\text { Sweeteners }\end{array}$ & & \\
\hline & & & & $80.587 \%$ & $\mathbf{1 1 7 . 1 1 8 \%}$ & $0.00012 \%$ & & \\
\hline & & & & \multicolumn{5}{|c|}{ Sweeteners consumption quantity change (\%) } \\
\hline & & & & Sugars & $\begin{array}{c}\text { Corn } \\
\text { Sweeteners }\end{array}$ & $\begin{array}{c}\text { Other } \\
\text { Sweeteners }\end{array}$ & $\begin{array}{c}\text { Artificial } \\
\text { Sweeteners }\end{array}$ & $\begin{array}{c}\text { All } \\
\text { Sweeteners } \\
\text { (sugar } \\
\text { equivalent) }\end{array}$ \\
\hline Milk & 100.44 & 1.009 & -0.828 & -5.716 & -22.420 & 4.527 & 34.928 & -14.824 \\
\hline Cheese & 65.55 & 1.001 & 0.014 & -4.970 & -25.015 & 2.409 & 0.713 & -17.386 \\
\hline Ice cream / yogurt & 27.39 & 1.015 & -1.285 & -6.205 & -16.930 & 5.699 & 30.301 & -11.043 \\
\hline $\begin{array}{l}\text { Breakfast cereal / } \\
\text { Bakery }\end{array}$ & 149.78 & 1.014 & -0.548 & -18.967 & -9.745 & 4.770 & 24.697 & -14.317 \\
\hline Soft drink & 118.41 & 1.027 & -2.595 & -7.449 & -32.239 & 20.036 & 11.266 & -25.850 \\
\hline Juice & 42.96 & 1.007 & -0.193 & -5.273 & -27.483 & 12.954 & 3.424 & -20.345 \\
\hline Sweetener products & 87.56 & 1.075 & -3.680 & -25.391 & -15.360 & 26.734 & -2.430 & -21.231 \\
\hline $\begin{array}{l}\text { Processed fruits and } \\
\text { vegetables }\end{array}$ & 29.39 & 1.007 & -1.266 & -6.379 & -28.581 & 8.161 & 1.271 & -21.411 \\
\hline Condiments / Spices & 104.65 & 1.003 & -0.344 & -5.845 & -12.954 & 0.229 & 4.298 & -6.761 \\
\hline Sweeteners & $\begin{array}{r}\text { Initial pe } \\
\text { sweeteners c } \\
\text { (lb }\end{array}$ & $\begin{array}{l}\text { capita } \\
\text { nsumption } \\
\text { ) }\end{array}$ & $\begin{array}{r}\text { Swe } \\
\text { consumpt } \\
\text { char } \\
\end{array}$ & $\begin{array}{l}\text { ners } \\
\text { quantity } \\
\text { (\%) }\end{array}$ & $\begin{array}{r}\text { Initial p } \\
\text { sweeteners } \\
\text { (do) }\end{array}$ & $\begin{array}{l}\text { capita } \\
\text { nsumption } \\
\text { irs) }\end{array}$ & $\begin{array}{r}\text { Sweeteners } \\
\text { value ch }\end{array}$ & $\begin{array}{l}\text { consumption } \\
\text { ange }(\%)\end{array}$ \\
\hline $\begin{array}{l}\text { All Sweeteners } \\
\text { (sugar equivalent) }^{\text {b }}\end{array}$ & 105 & & & & & & & 139 \\
\hline Sugars & 61. & & & & & & & 016 \\
\hline Corn Sweeteners & 54. & & & & & & 100 & 228 \\
\hline Other Sweeteners & 2.8 & & & & & & & 68 \\
\hline
\end{tabular}




\begin{tabular}{|c|c|c|c|c|}
\hline Artificial Sweeteners & 0.54 & 3.282 & 0.61 & 3.282 \\
\hline $\begin{array}{l}\text { Real expenditure on } \\
\text { above nine foods }\end{array}$ & \multicolumn{2}{|c|}{ Initial per capita real expenditure (dollars) } & \multicolumn{2}{|c|}{ Real expenditure change (\%) } \\
\hline & & & & \\
\hline Welfare & \multicolumn{4}{|c|}{ Market welfare change } \\
\hline EV (million dollars) & \multicolumn{4}{|c|}{-3908.899} \\
\hline Per capita EV (dollars) & \multicolumn{4}{|c|}{-13.947} \\
\hline EV/Income (\%) & \multicolumn{4}{|c|}{0.074} \\
\hline
\end{tabular}

Source: Elasticities for final products are from USDA/ERS, 2008a and Chouinard et al. 2010 (see Tables 6 and 7).

a. Initial prices are normalized to $\$ 1 /$ unit.

b. See Table 10, footnote b. 
Appendix L. Price Elasticity between the Sweeteners for Nine Sweetener-Intensive Foods (Reduce the Substitutability between Sweeteners by One-Half) ${ }^{\mathrm{a}}$

\begin{tabular}{|c|c|c|c|c|c|c|}
\hline Food & Sweeteners & Sugars & $\begin{array}{c}\text { Corn } \\
\text { Sweeteners }\end{array}$ & $\begin{array}{c}\text { Other } \\
\text { Sweeteners }\end{array}$ & $\begin{array}{c}\text { Artificial } \\
\text { Sweeteners }\end{array}$ & $\begin{array}{l}\text { All other } \\
\text { inputs }\end{array}$ \\
\hline \multirow{5}{*}{ Milk } & Sugars & -0.4800000 & $0.3000000^{\mathrm{C}}$ & $0.0000350^{\mathrm{d}}$ & $0.0000700^{\mathrm{d}}$ & 0.1798950 \\
\hline & $\begin{array}{c}\text { Corn } \\
\text { Sweeteners } \\
\end{array}$ & 0.2131978 & -0.4800000 & $0.0000350^{\mathrm{d}}$ & $0.0000700^{\mathrm{d}}$ & 0.2666972 \\
\hline & $\begin{array}{c}\text { Other } \\
\text { Sweeteners }\end{array}$ & 0.0154623 & 0.0217576 & -0.4800000 & $0.0000700^{\mathrm{d}}$ & 0.4427101 \\
\hline & $\begin{array}{c}\text { Artificial } \\
\text { Sweeteners }\end{array}$ & 0.0913560 & 0.1285511 & 0.0002068 & -0.4800000 & 0.2598860 \\
\hline & $\begin{array}{l}\text { All other } \\
\text { materials }\end{array}$ & 0.0009419 & 0.0019650 & 0.0000052 & 0.0000010 & -0.0029132 \\
\hline \multirow{5}{*}{ Cheese } & Sugars & -0.4800000 & $0.3000000^{\mathrm{C}}$ & $0.0002500^{\mathrm{e}}$ & $0.0002500^{\mathrm{e}}$ & 0.1795000 \\
\hline & $\begin{array}{c}\text { Corn } \\
\text { Sweeteners }\end{array}$ & 0.1423019 & -0.4800000 & $0.0002500^{\mathrm{e}}$ & $0.0002500^{\mathrm{e}}$ & 0.3371981 \\
\hline & $\begin{array}{c}\text { Other } \\
\text { Sweeteners }\end{array}$ & 0.0053149 & 0.0112048 & -0.4800000 & $0.0002500^{\mathrm{e}}$ & 0.4632303 \\
\hline & $\begin{array}{c}\text { Artificial } \\
\text { Sweeteners }\end{array}$ & 0.0015631 & 0.0032952 & 0.0000735 & -0.4800000 & 0.4750682 \\
\hline & $\begin{array}{l}\text { All other } \\
\text { materials }\end{array}$ & 0.0000685 & 0.0002714 & 0.0000083 & 0.0000290 & -0.0003772 \\
\hline \multirow{5}{*}{$\begin{array}{l}\text { Ice cream / } \\
\text { yogurt }\end{array}$} & Sugars & -0.4800000 & $0.3000000^{\mathrm{C}}$ & $0.0001000^{\mathrm{d}}$ & $0.0002000^{\mathrm{d}}$ & 0.1797000 \\
\hline & $\begin{array}{c}\text { Corn } \\
\text { Sweeteners }\end{array}$ & 0.3376790 & -0.4800000 & $0.0001000^{\mathrm{d}}$ & $0.0002000^{\mathrm{d}}$ & 0.1420210 \\
\hline & $\begin{array}{c}\text { Other } \\
\text { Sweeteners }\end{array}$ & 0.0267081 & 0.0237280 & -0.4800000 & $0.0002000^{\mathrm{d}}$ & 0.4293639 \\
\hline & $\begin{array}{c}\text { Artificial } \\
\text { Sweeteners }\end{array}$ & 0.1084605 & 0.0963582 & 0.0004061 & -0.4800000 & 0.2747752 \\
\hline & $\begin{array}{l}\text { All other } \\
\text { materials }\end{array}$ & 0.0021058 & 0.0014785 & 0.0000188 & 0.0000059 & -0.0036091 \\
\hline \multirow{5}{*}{$\begin{array}{l}\text { Breakfast } \\
\text { cereal / } \\
\text { Bakery }\end{array}$} & Sugars & -0.4800000 & $0.1000000^{f}$ & $0.0050000^{\mathrm{g}}$ & $0.0025000^{\mathrm{h}}$ & 0.3725000 \\
\hline & $\begin{array}{c}\text { Corn } \\
\text { Sweeteners }\end{array}$ & 0.4631372 & -0.4800000 & $0.0050000^{\mathrm{g}}$ & $0.0025000^{\mathrm{h}}$ & 0.0093628 \\
\hline & $\begin{array}{c}\text { Other } \\
\text { Sweeteners }\end{array}$ & 0.0334494 & 0.0072224 & -0.4800000 & $0.0025000^{\mathrm{h}}$ & 0.4368282 \\
\hline & $\begin{array}{c}\text { Artificial } \\
\text { Sweeteners }\end{array}$ & 0.1482334 & 0.0320064 & 0.0221579 & -0.4800000 & 0.2776024 \\
\hline & $\begin{array}{l}\text { All other } \\
\text { materials }\end{array}$ & 0.0072215 & 0.0000392 & 0.0012659 & 0.0000908 & -0.0086174 \\
\hline
\end{tabular}




\begin{tabular}{|c|c|c|c|c|c|c|}
\hline \multirow{5}{*}{ Soft drink } & Sugars & -0.4800000 & $0.3000000^{\mathrm{C}}$ & $0.0050000^{\mathrm{g}}$ & $0.0025000^{\mathrm{h}}$ & 0.1725000 \\
\hline & $\begin{array}{c}\text { Corn } \\
\text { Sweeteners }\end{array}$ & 0.0156372 & -0.4800000 & $0.0050000^{\mathrm{g}}$ & $0.0025000^{\mathrm{h}}$ & 0.4568628 \\
\hline & $\begin{array}{c}\text { Other } \\
\text { Sweeteners }\end{array}$ & 0.0067546 & 0.1295865 & -0.4800000 & $0.0025000^{\mathrm{h}}$ & 0.3411590 \\
\hline & $\begin{array}{c}\text { Artificial } \\
\text { Sweeteners }\end{array}$ & 0.0043016 & 0.0825266 & 0.0031842 & -0.4800000 & 0.3899876 \\
\hline & $\begin{array}{l}\text { All other } \\
\text { materials }\end{array}$ & 0.0003136 & 0.0159349 & 0.0004591 & 0.0004121 & -0.0171197 \\
\hline \multirow{5}{*}{ Juice } & Sugars & -0.4800000 & $0.3000000^{\mathrm{C}}$ & $0.0002500^{\mathrm{e}}$ & $0.0002500^{\mathrm{e}}$ & 0.1795000 \\
\hline & $\begin{array}{c}\text { Corn } \\
\text { Sweeteners }\end{array}$ & 0.0910859 & -0.4800000 & $0.0002500^{\mathrm{e}}$ & $0.0002500^{\mathrm{e}}$ & 0.3884141 \\
\hline & $\begin{array}{c}\text { Other } \\
\text { Sweeteners }\end{array}$ & 0.0198553 & 0.0653953 & -0.4800000 & $0.0002500^{\mathrm{e}}$ & 0.3944994 \\
\hline & $\begin{array}{c}\text { Artificial } \\
\text { Sweeteners }\end{array}$ & 0.0058393 & 0.0192322 & 0.0000735 & -0.4800000 & 0.4548550 \\
\hline & $\begin{array}{l}\text { All other } \\
\text { materials }\end{array}$ & 0.0003939 & 0.0028070 & 0.0000109 & 0.0000427 & -0.0032544 \\
\hline \multirow{5}{*}{$\begin{array}{l}\text { Sweetener } \\
\text { Products }\end{array}$} & Sugars & -0.4800000 & $0.0400000^{f}$ & $0.0015000^{\mathrm{f}}$ & $0.0005000^{\mathrm{t}}$ & 0.4380000 \\
\hline & $\begin{array}{c}\text { Corn } \\
\text { Sweeteners }\end{array}$ & 0.4154983 & -0.4800000 & $0.0015000^{f}$ & $0.0005000^{f}$ & 0.0625017 \\
\hline & $\begin{array}{c}\text { Other } \\
\text { Sweeteners }\end{array}$ & 0.2081608 & 0.0200396 & -0.4800000 & $0.0005000^{\mathrm{f}}$ & 0.2512996 \\
\hline & $\begin{array}{c}\text { Artificial } \\
\text { Sweeteners }\end{array}$ & 0.0117254 & 0.0011288 & 0.0000845 & -0.4800000 & 0.4670613 \\
\hline & $\begin{array}{l}\text { All other } \\
\text { materials }\end{array}$ & 0.0539663 & 0.0007414 & 0.0002231 & 0.0024539 & -0.0573847 \\
\hline \multirow{5}{*}{$\begin{array}{l}\text { Processed } \\
\text { fruits and } \\
\text { vegetables }\end{array}$} & Sugars & -0.4800000 & $0.3000000^{\mathrm{C}}$ & $0.0002500^{\mathrm{e}}$ & $0.0002500^{\mathrm{e}}$ & 0.1795000 \\
\hline & $\begin{array}{c}\text { Corn } \\
\text { Sweeteners }\end{array}$ & 0.0851322 & -0.4800000 & $0.0002500^{\mathrm{e}}$ & $0.0002500^{\mathrm{e}}$ & 0.3943678 \\
\hline & $\begin{array}{c}\text { Other } \\
\text { Sweeteners }\end{array}$ & 0.0140309 & 0.0494438 & -0.4800000 & $0.0002500^{\mathrm{e}}$ & 0.4162754 \\
\hline & $\begin{array}{c}\text { Artificial } \\
\text { Sweeteners }\end{array}$ & 0.0041264 & 0.0145410 & 0.0000735 & -0.4800000 & 0.4612591 \\
\hline & $\begin{array}{l}\text { All other } \\
\text { materials }\end{array}$ & 0.0004072 & 0.0031523 & 0.0000168 & 0.0000634 & -0.0036397 \\
\hline \multirow{4}{*}{$\begin{array}{l}\text { Condiments } \\
\text { /Spices }\end{array}$} & Sugars & -0.4800000 & $0.3000000^{\mathrm{C}}$ & $0.0050000^{\mathrm{g}}$ & $0.0025000^{\mathrm{h}}$ & 0.1725000 \\
\hline & $\begin{array}{c}\text { Corn } \\
\text { Sweeteners } \\
\end{array}$ & 0.4102984 & -0.4800000 & $0.0050000^{\mathrm{g}}$ & $0.0025000^{\mathrm{h}}$ & 0.0622016 \\
\hline & $\begin{array}{c}\text { Other } \\
\text { Sweeteners }\end{array}$ & 0.0049216 & 0.0035986 & -0.4800000 & $0.0025000^{\mathrm{h}}$ & 0.4689798 \\
\hline & $\begin{array}{c}\text { Artificial } \\
\text { Sweeteners }\end{array}$ & 0.0221038 & 0.0161617 & 0.0224557 & -0.4800000 & 0.4192788 \\
\hline
\end{tabular}




\begin{tabular}{|l|l|l|l|l|l|l|}
\hline & $\begin{array}{c}\text { All other } \\
\text { materials }\end{array}$ & 0.0004851 & 0.0001279 & 0.0013399 & 0.0001334 & -0.0020863 \\
\hline
\end{tabular}

a. The own-price elasticity of sweeteners is set to -0.48 . The lower triangle elements are derived from the upper triangle elements because their ratios are proportional to their cost shares' ratio based on the definition of Hessian matrix in the production.

b. The price elasticities of sweeteners to "All Other Inputs" are derived using the homogeneity property of the Hessian matrix from the output-constant cost function of food manufacturers with respect to prices. c. The cross-price elasticity of Sugars with respect to Corn Sweeteners is set to 0.30 .

d. There is no usage of Other Sweeteners in the final products "Milk" and "Ice cream / yogurt." For "Milk," the cross-price elasticities of Sugars and Corn Sweeteners with respect to Other Sweeteners are both set to 0.000035; the cross-price elasticities of Sugars, Corn Sweeteners, and Other Sweeteners with respect to Artificial Sweeteners are all set to 0.00007 . For "Ice cream / yogurt," these two numbers are set to 0.0001 and 0.0002 .

e. If there is neither Other Sweeteners nor Artificial Sweeteners used, the sweeteners' cross-price elasticities in the upper triangle are all set to 0.00025 except the one between Sugars and Corn Sweeteners.

f. The concavity curvature of the cost function requires that the Hessian matrix be negative semi-definite. When some sweeteners' cost shares are very small or equal to zero, the corresponding elements in the upper triangle of the input price elasticity matrix need to be set to smaller values to satisfy the homogeneity condition.

g. The cross-price elasticities of Sugars and Corn Sweeteners with respect to Other Sweeteners are both set to 0.005 .

h. The cross-price elasticities of Sugars, Corn Sweeteners, and Other Sweeteners with respect to Artificial Sweeteners are all set to 0.0025 . 
Appendix M. Changes for All Households with Tax for Nine Sweetener-Intensive Foods (Reduce the Substitutability between Sweeteners by One-Half)

M-1. Changes for All Households with Tax on the Price of Caloric Sweeteners (Reduce the Substitutability between Sweeteners by One-Half)

\begin{tabular}{|c|c|c|c|c|c|c|c|c|}
\hline \multirow{5}{*}{ Food } & \multirow{5}{*}{$\begin{array}{l}\text { Initial per } \\
\text { capita food } \\
\text { demand } \\
\text { (dollars) }^{\mathrm{a}}\end{array}$} & \multirow{5}{*}{$\begin{array}{l}\text { Price with } \\
\quad \text { tax }\end{array}$} & \multirow{5}{*}{$\begin{array}{c}\text { Food } \\
\text { demand } \\
\text { change } \\
(\%)\end{array}$} & \multicolumn{5}{|c|}{ Tax rate } \\
\hline & & & & Sugars & $\begin{array}{c}\text { Corn } \\
\text { Sweeteners }\end{array}$ & $\begin{array}{c}\text { Other } \\
\text { Sweeteners }\end{array}$ & & \\
\hline & & & & $27.234 \%$ & $42.836 \%$ & $0.00004 \%$ & & \\
\hline & & & & \multicolumn{5}{|c|}{ Sweeteners consumption quantity change (\%) } \\
\hline & & & & Sugars & $\begin{array}{c}\text { Corn } \\
\text { Sweeteners }\end{array}$ & $\begin{array}{c}\text { Other } \\
\text { Sweeteners }\end{array}$ & $\begin{array}{c}\text { Artificial } \\
\text { Sweeteners }\end{array}$ & $\begin{array}{c}\text { All } \\
\text { Sweeteners } \\
\text { (sugar } \\
\text { equivalent) }\end{array}$ \\
\hline Milk & 100.44 & 1.004 & -0.368 & -1.202 & -11.592 & 0.808 & 6.652 & -7.416 \\
\hline Cheese & 65.55 & 1.000 & -0.002 & -0.864 & -12.793 & 0.527 & 0.153 & -8.947 \\
\hline Ice cream / yogurt & 27.39 & 1.006 & -0.557 & -1.414 & -9.098 & 0.935 & 5.643 & -5.244 \\
\hline $\begin{array}{l}\text { Breakfast cereal / } \\
\text { Bakery }\end{array}$ & 149.78 & 1.006 & -0.231 & -7.845 & -5.948 & 0.893 & 4.642 & -6.685 \\
\hline Soft drink & 118.41 & 1.012 & -1.179 & -2.030 & -16.408 & 3.663 & 1.878 & -14.264 \\
\hline Juice & 42.96 & 1.003 & -0.104 & -1.025 & -14.001 & 2.681 & 0.664 & -10.716 \\
\hline Sweetener products & 87.56 & 1.030 & -1.487 & -11.078 & -8.343 & 4.208 & -1.275 & -10.105 \\
\hline $\begin{array}{l}\text { Processed fruits and } \\
\text { vegetables }\end{array}$ & 29.39 & 1.003 & -0.578 & -1.527 & -14.560 & 1.438 & -0.055 & -11.328 \\
\hline Condiments / Spices & 104.65 & 1.001 & -0.149 & -1.251 & -7.340 & -0.146 & 0.718 & -3.173 \\
\hline Sweeteners & $\begin{array}{r}\text { Initial p } \\
\text { sweeteners } \\
\text { (ll }\end{array}$ & $\begin{array}{l}\text { capita } \\
\text { nsumption }\end{array}$ & $\begin{array}{r}\text { Swee } \\
\text { consu } \\
\text { quantity }\end{array}$ & $\begin{array}{l}\text { ners } \\
\text { ption } \\
\text { ange (\%) }\end{array}$ & $\begin{array}{r}\text { Initial p } \\
\text { sweeteners } \\
\text { (dol }\end{array}$ & $\begin{array}{l}\text { capita } \\
\text { nsumption } \\
\text { Irs) }\end{array}$ & $\begin{array}{r}\text { Sweeteners } \\
\text { value ch }\end{array}$ & $\begin{array}{l}\text { onsumption } \\
\text { nge (\%) }\end{array}$ \\
\hline $\begin{array}{l}\text { All Sweeteners } \\
\text { (sugar equivalent) }^{\mathrm{b}}\end{array}$ & & & & & 22 & & & \\
\hline
\end{tabular}




\begin{tabular}{|c|c|c|c|c|}
\hline Sugars & 61.90 & -8.880 & 13.8 & 17.357 \\
\hline Corn Sweeteners & 54.81 & -12.405 & 7.31 & 28.709 \\
\hline Other Sweeteners & 2.86 & 1.276 & 0.94 & 1.296 \\
\hline Artificial Sweeteners & 0.54 & -0.043 & 0.61 & -0.043 \\
\hline $\begin{array}{l}\text { Real expenditure on } \\
\text { above nine foods }\end{array}$ & \multicolumn{2}{|c|}{ Initial per capita real expenditure (dollars) } & \multicolumn{2}{|c|}{ Real expenditure change (\%) } \\
\hline & \multicolumn{2}{|c|}{726.13} & \multicolumn{2}{|c|}{0.273} \\
\hline Welfare & \multicolumn{4}{|c|}{ Market welfare change } \\
\hline EV (million dollars) & \multicolumn{4}{|c|}{-1668.099} \\
\hline Per capita EV (dollars) & \multicolumn{4}{|c|}{-5.952} \\
\hline EV/Income (\%) & \multicolumn{4}{|c|}{0.032} \\
\hline
\end{tabular}

Source: Elasticities for final products are from USDA/ERS, 2008a and Chouinard et al. 2010 (see Tables 6 and 7).

a. Initial prices are normalized to $\$ 1 /$ unit.

b. See Table 10, footnote b. 
M-2. Changes for All Households with Tax on the Price for Individual Sweetener (Reduce the Substitutability between Sweeteners by One-Half)

\begin{tabular}{|c|c|c|c|c|c|}
\hline \multirow{4}{*}{ Food } & \multirow{4}{*}{$\begin{array}{l}\text { Initial per capita } \\
\text { food demand } \\
\text { (dollars) }^{\mathbf{a}}\end{array}$} & \multicolumn{2}{|c|}{$\begin{array}{c}\text { Tax on the price of } \\
\text { Sugars }\end{array}$} & \multicolumn{2}{|c|}{$\begin{array}{l}\text { Tax on the price of } \\
\text { Corn Sweeteners }\end{array}$} \\
\hline & & \multicolumn{4}{|c|}{ Tax rate } \\
\hline & & \multicolumn{2}{|c|}{$60.879 \%$} & \multicolumn{2}{|c|}{$154.311 \%$} \\
\hline & & $\begin{array}{c}\text { Price } \\
\text { with tax }\end{array}$ & $\begin{array}{c}\text { Food } \\
\text { demand } \\
\text { change } \\
(\%)\end{array}$ & $\begin{array}{c}\text { Price } \\
\text { with tax }\end{array}$ & $\begin{array}{c}\text { Food } \\
\text { demand } \\
\text { change } \\
(\%)\end{array}$ \\
\hline Milk & 100.44 & 1.002 & -0.181 & 1.007 & -0.726 \\
\hline Cheese & 65.55 & 1.000 & 0.100 & 1.001 & -0.137 \\
\hline Ice cream / yogurt & 27.39 & 1.005 & -0.485 & 1.010 & -0.816 \\
\hline $\begin{array}{l}\text { Breakfast cereal / } \\
\text { Bakery }\end{array}$ & 149.78 & 1.009 & -0.328 & 1.004 & -0.169 \\
\hline Soft drink & 118.41 & 1.001 & -0.091 & 1.032 & -2.992 \\
\hline Juice & 42.96 & 1.001 & 0.188 & 1.007 & -0.519 \\
\hline Sweetener products & 87.56 & 1.053 & -2.620 & 1.010 & -0.453 \\
\hline $\begin{array}{l}\text { Processed fruits and } \\
\text { vegetables }\end{array}$ & 29.39 & 1.001 & -0.061 & 1.007 & -1.435 \\
\hline Condiments / Spices & 104.65 & 1.001 & -0.142 & 1.002 & -0.202 \\
\hline Sweeteners & $\begin{array}{l}\text { Initial per capita } \\
\text { sweeteners } \\
\text { consumption (lbs) }\end{array}$ & \multicolumn{4}{|c|}{$\begin{array}{l}\text { Sweeteners consumption quantity change } \\
\qquad(\%)\end{array}$} \\
\hline $\begin{array}{l}\text { All Sweeteners } \\
\text { (sugar equivalent) }^{\mathrm{b}}\end{array}$ & 105.69 & \multicolumn{2}{|c|}{-10.000} & \multicolumn{2}{|c|}{-10.000} \\
\hline Sugars & 61.90 & \multicolumn{2}{|c|}{-21.996} & \multicolumn{2}{|c|}{7.639} \\
\hline Corn Sweeteners & 54.81 & \multicolumn{2}{|c|}{7.367} & \multicolumn{2}{|c|}{-37.325} \\
\hline Other Sweeteners & 2.86 & \multicolumn{2}{|c|}{1.130} & \multicolumn{2}{|c|}{1.830} \\
\hline Artificial Sweeteners & 0.54 & \multicolumn{2}{|c|}{-0.886} & \multicolumn{2}{|c|}{0.995} \\
\hline Sweeteners & $\begin{array}{c}\text { Initial per capita } \\
\text { sweeteners } \\
\text { consumption } \\
\text { (dollars) } \\
\end{array}$ & \multicolumn{4}{|c|}{ Sweeteners consumption value change $(\%)$} \\
\hline All Sweeteners & 22.66 & \multicolumn{2}{|c|}{20.094} & \multicolumn{2}{|c|}{30.939} \\
\hline Sugars & 13.80 & \multicolumn{2}{|c|}{29.050} & \multicolumn{2}{|c|}{7.639} \\
\hline Corn Sweeteners & 7.31 & \multicolumn{2}{|c|}{7.367} & \multicolumn{2}{|c|}{81.137} \\
\hline Other Sweeteners & 0.94 & \multicolumn{2}{|c|}{1.130} & \multicolumn{2}{|c|}{1.830} \\
\hline Artificial Sweeteners & 0.61 & \multicolumn{2}{|c|}{-0.886} & \multicolumn{2}{|c|}{0.995} \\
\hline $\begin{array}{l}\text { Real expenditure on } \\
\text { nine foods }\end{array}$ & $\begin{array}{c}\text { Initial per capita } \\
\text { real expenditure } \\
\text { (dollars) }\end{array}$ & \multicolumn{4}{|c|}{ Real expenditure change (\%) } \\
\hline & 726.13 & \multicolumn{2}{|c|}{0.459} & \multicolumn{2}{|c|}{0.093} \\
\hline
\end{tabular}




\begin{tabular}{|l|c|c|c|}
\hline Welfare & \multicolumn{2}{|c|}{ Market welfare change } \\
\hline EV (million dollars) & & -1855.917 & -1913.940 \\
\hline Per capita EV (dollars) & -6.622 & -6.829 \\
\hline EV/Income (\%) & 0.035 & 0.036 \\
\hline
\end{tabular}

Source: Elasticities for final products are from USDA/ERS, 2008a and Chouinard et al. 2010 (see Tables 6 and 7).

a. Initial prices are normalized to $\$ 1 /$ unit.

b. See Table 10, footnote b. 


\section{Appendix N. Computation of Simulations}

\section{Computation of Food Price with Sweetener Input Tax}

If the tax imposed on the sweetener inputs is changed, we derived that

$$
d \ln P_{i}=d \ln P P_{i}=\sum_{k} s_{i k} d \ln w_{k}=\sum_{k} s_{i k} d \ln \left(1+t_{k}\right)
$$

By approximation, $\frac{P_{i}^{1}-P_{i}^{0}}{P_{i}^{0}} \approx \exp \left(d \ln P_{i}\right)-1=\exp \left[\sum_{k} s_{i k} d \ln \left(1+t_{k}\right)\right]-1$,

$$
P_{i}^{1} \approx P_{i}^{0} \exp \left[\sum_{k} s_{i k} d \ln \left(1+t_{k}\right)\right] \approx P_{i}^{0} \exp \left[\sum_{k} s_{i k} \ln \left(1+t_{k}\right)\right]
$$

\section{Computation of Sweetener Input Quantity Change}

We derived that $d \ln x_{h}=d \ln y+\sum_{k} \delta_{h k} d \ln \left(1+t_{k}\right)$.

The percentage change of the quantity of input $h$ can be approximated as

$$
\frac{x_{h}^{1}-x_{h}^{0}}{x_{h}^{0}} \approx \exp \left(d \ln x_{h}\right)-1 \approx \exp \left[\left(\ln y_{1}-\ln y_{0}\right)+\sum_{k} \delta_{h k} \ln \left(1+t_{k}\right)\right]-1 \text {. }
$$

\section{Computation of Sweetener Input Value Change}

If a tax is not imposed on the sweetener $h$, the percentage change of the value of input $h$ can be approximated as

$$
\frac{w_{h}^{0} x_{h}^{1}-w_{h}^{0} x_{h}^{0}}{w_{h}^{0} x_{h}^{0}}=\frac{x_{h}^{1}-x_{h}^{0}}{x_{h}^{0}} \approx \exp \left[\left(\ln y_{1}-\ln y_{0}\right)+\sum_{k} \delta_{h k} \ln \left(1+t_{k}\right)\right]-1,
$$

If a tax is imposed on the sweetener $h$, the percentage change of the value of input $h$ can be approximated as

$$
\left.\frac{w_{h}^{1} x_{h}^{1}-w_{h}^{0} x_{h}^{0}}{w_{h}^{0} x_{h}^{0}}=\frac{\left(1+t_{h}\right) x_{h}^{1}-x_{h}^{0}}{x_{h}^{0}}=\frac{\left(1+t_{h}\right)\left(x_{h}^{1}-x_{h}^{0}\right)}{x_{h}^{0}}+t_{h} \approx\left(1+t_{h}\right)\left\{\exp \left[\left(\ln y_{1}-\ln y_{0}\right)+\sum_{k} \delta_{h k} \ln \left(1+t_{k}\right)\right]-1\right)+t_{h}\right\} .
$$


Appendix O. Changes for All Households with Tax on the Price of All Sweeteners for Nine Sweetener-Intensive Foods

\begin{tabular}{|c|c|c|c|c|c|c|c|c|}
\hline \multirow{5}{*}{ Food } & \multirow{5}{*}{$\begin{array}{l}\text { Initial per } \\
\text { capita food } \\
\text { demand } \\
\text { (dollars) }^{\mathrm{a}}\end{array}$} & \multirow{5}{*}{ Price with tax } & \multirow{5}{*}{$\begin{array}{c}\text { Food } \\
\text { demand } \\
\text { change } \\
(\%)\end{array}$} & \multicolumn{5}{|c|}{ Tax rate } \\
\hline & & & & \multirow{3}{*}{$\begin{array}{l}\text { Sugars } \\
27.410 \% \\
\text { s }\end{array}$} & \multirow{2}{*}{$\begin{array}{r}\begin{array}{c}\text { Corn } \\
\text { Sweeteners }\end{array} \\
43.073 \% \\
\end{array}$} & \multirow{2}{*}{\begin{tabular}{|c|}
$\begin{array}{c}\text { Other } \\
\text { Sweeteners }\end{array}$ \\
$\mathbf{0 . 0 0 0 0 6 \%}$ \\
\end{tabular}} & \multirow{2}{*}{\begin{tabular}{|c|}
$\begin{array}{c}\text { Artificial } \\
\text { Sweeteners }\end{array}$ \\
$\mathbf{0 . 0 0 0 1 2 \%}$ \\
\end{tabular}} & \\
\hline & & & & & & & & \\
\hline & & & & & \multicolumn{4}{|c|}{ Sweeteners consumption quantity change (\%) } \\
\hline & & & & Sugars & $\begin{array}{c}\text { Corn } \\
\text { Sweeteners }\end{array}$ & $\begin{array}{c}\text { Other } \\
\text { Sweeteners }\end{array}$ & $\begin{array}{c}\text { Artificial } \\
\text { Sweeteners }\end{array}$ & $\begin{array}{c}\text { All } \\
\text { Sweeteners } \\
\text { (sugar } \\
\text { equivalent) }\end{array}$ \\
\hline Milk & 100.44 & 1.004 & -0.370 & -1.219 & -11.639 & 1.982 & 14.214 & -7.448 \\
\hline Cheese & 65.55 & 1.000 & -0.002 & -0.880 & -12.845 & 1.063 & 0.310 & -8.985 \\
\hline Ice cream / yogurt & 27.39 & 1.006 & -0.560 & -1.433 & -9.130 & 2.462 & 12.295 & -5.267 \\
\hline $\begin{array}{l}\text { Breakfast cereal / } \\
\text { Bakery }\end{array}$ & 149.78 & 1.006 & -0.232 & -7.892 & -5.964 & 1.982 & 9.746 & -6.645 \\
\hline Soft drink & 118.41 & 1.013 & -1.184 & -2.052 & -16.478 & 8.784 & 5.053 & -14.225 \\
\hline Juice & 42.96 & 1.003 & -0.104 & -1.042 & -14.060 & 5.635 & 1.507 & -10.760 \\
\hline Sweetener products & 87.56 & 1.030 & -1.496 & -11.139 & -8.372 & 10.413 & -0.962 & -10.133 \\
\hline $\begin{array}{l}\text { Processed fruits and } \\
\text { vegetables }\end{array}$ & 29.39 & 1.003 & -0.581 & -1.546 & -14.621 & 3.609 & 0.567 & -11.374 \\
\hline Condiments / Spices & 104.65 & 1.001 & -0.150 & -1.269 & -7.364 & 0.101 & 1.850 & -3.126 \\
\hline Sweeteners & \multicolumn{2}{|c|}{$\begin{array}{l}\text { Initial per capita sweeteners } \\
\text { consumption (lbs) }\end{array}$} & \multicolumn{2}{|c|}{$\begin{array}{c}\text { Sweeteners } \\
\text { consumption quantity } \\
\text { change }(\%)\end{array}$} & \multicolumn{2}{|c|}{$\begin{array}{c}\text { Initial per capita } \\
\text { sweeteners consumption } \\
\text { (dollars) }\end{array}$} & \multicolumn{2}{|c|}{$\begin{array}{l}\text { Sweeteners consumption } \\
\text { value change }(\%)\end{array}$} \\
\hline $\begin{array}{l}\text { All Sweeteners } \\
\text { (sugar equivalent) }^{\mathrm{b}}\end{array}$ & \multicolumn{2}{|c|}{105.69} & \multicolumn{2}{|c|}{-10.000} & \multicolumn{2}{|c|}{22.66} & \multicolumn{2}{|c|}{20.143} \\
\hline Sugars & \multicolumn{2}{|c|}{61.90} & \multicolumn{2}{|c|}{-8.929} & \multicolumn{2}{|c|}{13.80} & \multicolumn{2}{|c|}{17.474} \\
\hline Corn Sweeteners & \multicolumn{2}{|c|}{54.81} & \multicolumn{2}{|c|}{-12.451} & \multicolumn{2}{|c|}{7.31} & \multicolumn{2}{|c|}{28.894} \\
\hline Other Sweeteners & \multicolumn{2}{|c|}{2.86} & \multirow{2}{*}{\multicolumn{2}{|c|}{$\begin{array}{l}3.223 \\
1225\end{array}$}} & \multicolumn{2}{|c|}{0.94} & \multicolumn{2}{|c|}{3.348} \\
\hline Artificial Sweeteners & \multicolumn{2}{|c|}{0.54} & & & \multicolumn{2}{|c|}{0.61} & \\
\hline
\end{tabular}




\begin{tabular}{|l|c|c|}
\hline $\begin{array}{l}\text { Real expenditure } \\
\text { on above nine foods }\end{array}$ & Initial per capita real expenditure (dollars) & Real expenditure change (\%) \\
\hline & 726.13 & 0.275 \\
\hline Welfare & Market welfare change \\
\hline EV (million dollars) & -1676.919 \\
\hline $\begin{array}{l}\text { Per capita EV } \\
\text { (dollars) }\end{array}$ & -5.983 \\
\hline EV/Income (\%) & 0.032 \\
\hline
\end{tabular}

Source: Elasticities for final products are from USDA/ERS, 2008a and Chouinard et al. 2010 (see Tables 6 and 7).

a. Initial prices are normalized to $\$ 1 /$ unit.

b. See Table 10, footnote b. 
Appendix P. Changes on All Households and Disaggregated Income Groups with Tax on the Price of All Sweeteners for Nine Sweetener-Intensive Foods

\begin{tabular}{|c|c|c|c|c|c|c|c|c|c|c|c|c|}
\hline \multirow{4}{*}{ Food } & \multirow{2}{*}{\multicolumn{2}{|c|}{ All households }} & \multicolumn{10}{|c|}{ Food demand by household quintiles } \\
\hline & & & \multicolumn{2}{|c|}{ Lowest $20 \%$} & \multicolumn{2}{|c|}{ Second $20 \%$} & \multicolumn{2}{|c|}{ Third $20 \%$} & \multicolumn{2}{|c|}{ Fourth 20\% } & \multicolumn{2}{|c|}{ Highest 20\% } \\
\hline & \multicolumn{12}{|c|}{ Food demand (per capita) } \\
\hline & $\begin{array}{c}\text { Initial } \\
\text { value } \\
\text { (dollars) }^{\mathrm{a}}\end{array}$ & $\begin{array}{c}\text { Change } \\
(\%)\end{array}$ & $\begin{array}{c}\text { Initial } \\
\text { value } \\
\text { (dollars) }^{\mathrm{a}}\end{array}$ & $\begin{array}{c}\text { Change } \\
\text { (\%) }\end{array}$ & $\begin{array}{c}\text { Initial } \\
\text { value } \\
\text { (dollars) }^{a}\end{array}$ & $\begin{array}{c}\text { Change } \\
(\%)\end{array}$ & $\begin{array}{c}\text { Initial } \\
\text { value } \\
\text { (dollars) }^{a}\end{array}$ & $\begin{array}{c}\text { Change } \\
\text { (\%) }\end{array}$ & $\begin{array}{c}\text { Initial } \\
\text { value } \\
\text { (dollars) }^{a}\end{array}$ & $\begin{array}{c}\text { Change } \\
(\%)\end{array}$ & $\begin{array}{c}\text { Initial } \\
\text { value } \\
\text { (dollars) }^{a}\end{array}$ & $\begin{array}{c}\text { Change } \\
(\%)\end{array}$ \\
\hline Milk & 100.44 & -0.370 & 104.98 & -0.517 & 107.31 & -0.390 & 95.18 & -0.387 & 99.59 & -0.330 & 98.18 & -0.293 \\
\hline Cheese & 65.55 & -0.002 & 60.44 & 0.000 & 56.54 & -0.002 & 62.73 & -0.002 & 66.77 & -0.003 & 75.57 & -0.003 \\
\hline $\begin{array}{l}\text { Ice cream / } \\
\text { yogurt }\end{array}$ & 27.39 & -0.560 & 25.26 & -0.889 & 23.62 & -0.733 & 26.21 & -0.581 & 27.90 & -0.486 & 31.58 & -0.375 \\
\hline $\begin{array}{l}\text { Breakfast } \\
\text { cereal / } \\
\text { Bakery }\end{array}$ & 149.78 & -0.232 & 150.03 & -0.336 & 141.06 & -0.277 & 138.98 & -0.248 & 148.90 & -0.208 & 164.84 & -0.165 \\
\hline Soft drink & 118.41 & -1.184 & 114.12 & -1.795 & 109.23 & -1.448 & 112.87 & -1.233 & 120.07 & -1.034 & 129.86 & -0.836 \\
\hline Juice & 42.96 & -0.104 & 41.98 & -0.151 & 40.55 & -0.122 & 40.33 & -0.110 & 42.70 & -0.094 & 47.40 & -0.076 \\
\hline $\begin{array}{l}\text { Processed } \\
\text { fruits and } \\
\text { vegetables }\end{array}$ & 29.39 & -0.581 & 28.84 & -0.858 & 27.74 & -0.691 & 28.36 & -0.597 & 29.48 & -0.514 & 31.53 & -0.423 \\
\hline $\begin{array}{l}\text { Condiments / } \\
\text { Spices }\end{array}$ & 104.65 & -0.150 & 90.40 & -0.252 & 93.45 & -0.188 & 101.54 & -0.153 & 108.64 & -0.128 & 118.83 & -0.103 \\
\hline \multirow[b]{2}{*}{ Sweeteners } & \multicolumn{12}{|c|}{ Sweeteners consumption quantities (per capita) } \\
\hline & $\begin{array}{c}\text { Initial } \\
\text { value } \\
\text { (lbs) } \\
\end{array}$ & $\begin{array}{c}\text { Change } \\
(\%)\end{array}$ & $\begin{array}{c}\text { Initial } \\
\text { value } \\
\text { (lbs) } \\
\end{array}$ & $\begin{array}{c}\text { Change } \\
(\%)\end{array}$ & $\begin{array}{c}\text { Initial } \\
\text { value } \\
\text { (lbs) } \\
\end{array}$ & $\begin{array}{c}\text { Change } \\
(\%)\end{array}$ & $\begin{array}{c}\text { Initial } \\
\text { value } \\
\text { (lbs) }\end{array}$ & $\begin{array}{c}\text { Change } \\
(\%)\end{array}$ & $\begin{array}{c}\text { Initial } \\
\text { value } \\
\text { (lbs) }\end{array}$ & $\begin{array}{c}\text { Change } \\
\text { (\%) }\end{array}$ & $\begin{array}{c}\text { Initial } \\
\text { value } \\
\text { (lbs) }\end{array}$ & $\begin{array}{c}\text { Change } \\
(\%)\end{array}$ \\
\hline $\begin{array}{l}\text { All } \\
\text { Sweeteners } \\
\text { (sugar }^{\text {equivalent) }} \\
\text { eq }\end{array}$ & 105.69 & -10.000 & 103.83 & -10.450 & 97.85 & -10.193 & 101.28 & -10.039 & 105.85 & -9.899 & 115.37 & -9.727 \\
\hline Sugars & 61.90 & -8.929 & 61.21 & -9.434 & 56.96 & -9.115 & 59.54 & -8.981 & 61.73 & -8.803 & 67.67 & -8.643 \\
\hline
\end{tabular}




\begin{tabular}{|c|c|c|c|c|c|c|c|c|c|c|c|c|}
\hline \multicolumn{13}{|l|}{ Sweeteners } \\
\hline $\begin{array}{l}\text { Other } \\
\text { Sweeteners }\end{array}$ & 2.86 & 3.223 & 2.72 & 3.068 & 2.63 & 3.124 & 2.71 & 3.212 & 2.89 & 3.258 & 3.17 & 3.328 \\
\hline $\begin{array}{l}\text { Artificial } \\
\text { Sweeteners }\end{array}$ & 0.54 & 1.325 & 0.53 & 0.685 & 0.49 & 1.060 & 0.52 & 1.244 & 0.54 & 1.485 & 0.59 & 1.706 \\
\hline \multirow[b]{2}{*}{ Sweeteners } & \multicolumn{12}{|c|}{ Sweeteners consumption values (per capita) } \\
\hline & $\begin{array}{c}\text { Initial } \\
\text { value } \\
\text { (dollars) }\end{array}$ & $\begin{array}{c}\text { Change } \\
\text { (\%) }\end{array}$ & $\begin{array}{c}\text { Initial } \\
\text { value } \\
\text { (dollars) }\end{array}$ & $\begin{array}{c}\text { Change } \\
\text { (\%) }\end{array}$ & $\begin{array}{c}\text { Initial } \\
\text { value } \\
\text { (dollars) }\end{array}$ & $\begin{array}{c}\text { Change } \\
(\%)\end{array}$ & $\begin{array}{c}\text { Initial } \\
\text { value } \\
\text { (dollars) }\end{array}$ & $\begin{array}{c}\text { Change } \\
(\%)\end{array}$ & $\begin{array}{c}\text { Initial } \\
\text { value } \\
\text { (dollars) }\end{array}$ & $\begin{array}{c}\text { Change } \\
(\%)\end{array}$ & $\begin{array}{c}\text { Initial } \\
\text { value } \\
\text { (dollars) }\end{array}$ & $\begin{array}{c}\text { Change } \\
(\%)\end{array}$ \\
\hline $\begin{array}{l}\text { All } \\
\text { Sweeteners }\end{array}$ & 22.66 & 20.143 & 22.26 & 19.531 & 20.95 & 19.963 & 21.72 & 20.064 & 22.68 & 20.302 & 24.75 & 20.466 \\
\hline Sugars & 13.8 & 17.474 & 13.64 & 16.819 & 12.70 & 17.247 & 13.27 & 17.400 & 13.76 & 17.638 & 15.08 & 17.838 \\
\hline $\begin{array}{l}\text { Corn } \\
\text { Sweeteners }\end{array}$ & 7.31 & 28.894 & 7.12 & 28.335 & 6.84 & 28.649 & 6.97 & 28.847 & 7.37 & 29.006 & 7.95 & 29.245 \\
\hline $\begin{array}{l}\text { Other } \\
\text { Sweeteners }\end{array}$ & 0.94 & 3.348 & 0.89 & 3.195 & 0.87 & 3.249 & 0.89 & 3.338 & 0.95 & 3.383 & 1.04 & 3.452 \\
\hline $\begin{array}{l}\text { Artificial } \\
\text { Sweeteners }\end{array}$ & 0.61 & 1.400 & 0.59 & 0.761 & 0.55 & 1.137 & 0.58 & 1.317 & 0.61 & 1.561 & 0.66 & 1.782 \\
\hline \multirow{3}{*}{$\begin{array}{l}\text { Real } \\
\text { expenditure } \\
\text { on nine } \\
\text { foods }\end{array}$} & \multicolumn{12}{|c|}{ Real expenditure (per capita) } \\
\hline & $\begin{array}{c}\text { Initial } \\
\text { value } \\
\text { (dollars) }\end{array}$ & $\begin{array}{c}\text { Change } \\
(\%)\end{array}$ & $\begin{array}{c}\text { Initial } \\
\text { value } \\
\text { (dollars) }\end{array}$ & $\begin{array}{c}\text { Change } \\
(\%)\end{array}$ & $\begin{array}{c}\text { Initial } \\
\text { value } \\
\text { (dollars) }\end{array}$ & $\begin{array}{c}\text { Change } \\
(\%)\end{array}$ & $\begin{array}{c}\text { Initial } \\
\text { value } \\
\text { (dollars) }\end{array}$ & $\begin{array}{c}\text { Change } \\
(\%)\end{array}$ & $\begin{array}{c}\text { Initial } \\
\text { value } \\
\text { (dollars) }\end{array}$ & $\begin{array}{c}\text { Change } \\
(\%)\end{array}$ & $\begin{array}{c}\text { Initial } \\
\text { value } \\
\text { (dollars) }\end{array}$ & $\begin{array}{c}\text { Change } \\
(\%)\end{array}$ \\
\hline & 726.13 & 0.275 & 702.64 & 0.007 & 679.01 & 0.154 & 691.40 & 0.256 & 731.26 & 0.337 & 793.56 & 0.434 \\
\hline Welfare & \multicolumn{2}{|c|}{$\begin{array}{c}\text { Market welfare } \\
\text { change }\end{array}$} & \multicolumn{2}{|c|}{$\begin{array}{c}\text { Market welfare } \\
\text { change }\end{array}$} & \multicolumn{2}{|c|}{$\begin{array}{c}\text { Market welfare } \\
\text { change }\end{array}$} & \multicolumn{2}{|c|}{$\begin{array}{c}\text { Market welfare } \\
\text { change }\end{array}$} & \multicolumn{2}{|c|}{$\begin{array}{c}\text { Market welfare } \\
\text { change }\end{array}$} & \multicolumn{2}{|c|}{$\begin{array}{c}\text { Market welfare } \\
\text { change }\end{array}$} \\
\hline $\begin{array}{l}\text { EV (million } \\
\text { dollars) }\end{array}$ & \multicolumn{2}{|c|}{-1676.919} & \multicolumn{2}{|c|}{-225.008} & \multicolumn{2}{|c|}{-275.226} & \multicolumn{2}{|c|}{-323.775} & \multicolumn{2}{|c|}{-379.654} & \multicolumn{2}{|c|}{-473.256} \\
\hline $\begin{array}{l}\text { Per capita EV } \\
\text { (dollars) }\end{array}$ & \multicolumn{2}{|c|}{-5.983} & \multicolumn{2}{|c|}{-5.864} & \multicolumn{2}{|c|}{-5.537} & \multicolumn{2}{|c|}{-5.732} & \multicolumn{2}{|c|}{-5.997} & \multicolumn{2}{|c|}{-6.537} \\
\hline $\begin{array}{l}\text { EV/Income } \\
(\%)\end{array}$ & \multicolumn{2}{|c|}{0.032} & \multicolumn{2}{|c|}{0.121} & \multicolumn{2}{|c|}{0.059} & \multicolumn{2}{|c|}{0.040} & \multicolumn{2}{|c|}{0.030} & \multicolumn{2}{|c|}{0.019} \\
\hline
\end{tabular}

Source: Elasticities for final products are from USDA/ERS, 2008a and Chouinard et al. 2010 (see Tables 6 and 7).

a. Initial prices are normalized to $\$ 1 /$ unit.

b. See Table 10, footnote b. 
Appendix Q. Changes for All Households with Tax on the price of All Sweeteners for Nine Sweetener-Intensive Foods (Reduce the Sugar Equivalent Quantity of All Sweeteners by 20\%)

\begin{tabular}{|c|c|c|c|c|c|c|c|c|}
\hline \multirow{5}{*}{ Food } & \multirow{5}{*}{$\begin{array}{l}\text { Initial per } \\
\text { capita food } \\
\text { demand } \\
\text { (dollars) }^{\mathbf{a}}\end{array}$} & \multirow{5}{*}{$\begin{array}{c}\text { Price } \\
\text { with tax }\end{array}$} & \multirow{5}{*}{$\begin{array}{l}\text { Food } \\
\text { demand } \\
\text { change } \\
(\%)\end{array}$} & \multicolumn{5}{|c|}{ Tax rate } \\
\hline & & & & Sugars & $\begin{array}{c}\text { Corn } \\
\text { Sweeteners }\end{array}$ & $\begin{array}{c}\text { Other } \\
\text { Sweeteners }\end{array}$ & $\begin{array}{c}\text { Artificial } \\
\text { Sweeteners }\end{array}$ & \\
\hline & & & & $80.903 \%$ & $116.391 \%$ & $0.000126 \%$ & $0.000000001 \%$ & \\
\hline & & & & \multicolumn{5}{|c|}{ Sweeteners consumption quantity change (\%) } \\
\hline & & & & Sugars & $\begin{array}{c}\text { Corn } \\
\text { Sweeteners }\end{array}$ & $\begin{array}{c}\text { Other } \\
\text { Sweeteners }\end{array}$ & $\begin{array}{c}\text { Artificial } \\
\text { Sweeteners }\end{array}$ & $\begin{array}{c}\text { All } \\
\text { Sweeteners } \\
\text { (sugar }^{\text {(sugar }} \\
\text { equivalent) }\end{array}$ \\
\hline Milk & 100.44 & 1.009 & -0.826 & -5.888 & -22.265 & 4.519 & 34.858 & -14.803 \\
\hline Cheese & 65.55 & 1.001 & 0.015 & -5.144 & -24.875 & 2.404 & 0.712 & -17.352 \\
\hline Ice cream / yogurt & 27.39 & 1.015 & -1.284 & -6.377 & -16.746 & 5.693 & 30.268 & -11.038 \\
\hline $\begin{array}{l}\text { Breakfast cereal / } \\
\text { Bakery }\end{array}$ & 149.78 & 1.014 & -0.549 & -19.062 & -9.527 & 4.777 & 24.734 & -14.335 \\
\hline Soft drink & 118.41 & 1.027 & -2.584 & -7.610 & -32.120 & 19.948 & 11.218 & -25.776 \\
\hline Juice & 42.96 & 1.007 & -0.190 & -5.444 & -27.352 & 12.917 & 3.417 & -20.296 \\
\hline Sweetener products & 87.56 & 1.075 & -3.688 & -25.470 & -15.170 & 26.797 & -2.436 & -21.267 \\
\hline $\begin{array}{l}\text { Processed fruits and } \\
\text { vegetables }\end{array}$ & 29.39 & 1.007 & -1.261 & -6.546 & -28.451 & 8.137 & 1.268 & -21.360 \\
\hline Condiments / Spices & 104.65 & 1.003 & -0.344 & -6.018 & -12.751 & 0.229 & 4.295 & -6.761 \\
\hline Sweeteners & \multicolumn{2}{|c|}{$\begin{array}{l}\text { Initial per capita } \\
\text { sweeteners } \\
\text { consumption(lbs) }\end{array}$} & \multicolumn{2}{|c|}{$\begin{array}{c}\text { Sweeteners } \\
\text { consumption quantity } \\
\text { change }(\%)\end{array}$} & \multicolumn{2}{|c|}{$\begin{array}{c}\text { Initial per capita } \\
\text { sweeteners consumption } \\
\text { (dollars) }\end{array}$} & \multicolumn{2}{|c|}{$\begin{array}{l}\text { Sweeteners consumption } \\
\text { value change }(\%)\end{array}$} \\
\hline $\begin{array}{l}\text { All Sweeteners } \\
\text { (sugar equivalent) }^{b}\end{array}$ & \multicolumn{2}{|c|}{105.69} & \multicolumn{2}{|c|}{-20.000} & \multicolumn{2}{|c|}{22.66} & \multicolumn{2}{|c|}{68.062} \\
\hline Sugars & \multicolumn{2}{|c|}{61.90} & \multicolumn{2}{|c|}{-19.627} & \multicolumn{2}{|c|}{13.8} & \multicolumn{2}{|c|}{58.194} \\
\hline Corn Sweeteners & \multicolumn{2}{|c|}{54.81} & \multicolumn{2}{|c|}{-22.331} & \multicolumn{2}{|c|}{7.31} & \multicolumn{2}{|c|}{99.611} \\
\hline Other Sweeteners & \multicolumn{2}{|c|}{2.86} & \multicolumn{2}{|c|}{8.094} & \multicolumn{2}{|c|}{0.94} & \multicolumn{2}{|c|}{8.957} \\
\hline Artificial Sweeteners & \multicolumn{2}{|c|}{0.54} & \multicolumn{2}{|c|}{3.271} & \multicolumn{2}{|c|}{0.61} & \multicolumn{2}{|c|}{3.796} \\
\hline
\end{tabular}




\begin{tabular}{|l|c|c|}
\hline $\begin{array}{l}\text { Real expenditure on } \\
\text { above nine foods }\end{array}$ & Initial per capita real expenditure (dollars) & Real expenditure change (\%) \\
\hline & 726.13 & 0.644 \\
\hline Welfare & \multicolumn{2}{|c|}{ Market welfare change } \\
\hline EV (million dollars) & -3908.932 \\
\hline Per capita EV (dollars) & -13.947 \\
\hline EV/Income (\%) & 0.074 \\
\hline
\end{tabular}

Source: Elasticities for final products are from USDA/ERS, 2008a and Chouinard et al. 2010 (see Tables 6 and 7).

a. Initial prices are normalized to \$1/unit.

b. See Table 10, footnote b. 
Appendix R. Changes for All Households with Tax on the Price of All Sweeteners for Nine Sweetener-Intensive Foods (Reduce the Substitutability between Sweeteners by One-Half)

\begin{tabular}{|c|c|c|c|c|c|c|c|c|}
\hline \multirow{5}{*}{ Food } & \multirow{5}{*}{$\begin{array}{c}\text { Initial per } \\
\text { capita } \\
\text { food } \\
\text { demand } \\
\text { (dollars) }^{\mathrm{a}}\end{array}$} & \multirow{5}{*}{$\begin{array}{c}\text { Price } \\
\text { with tax }\end{array}$} & \multirow{5}{*}{$\begin{array}{c}\text { Food } \\
\text { demand } \\
\text { change } \\
(\%)\end{array}$} & \multicolumn{5}{|c|}{ Tax rate } \\
\hline & & & & \multirow{3}{*}{$\begin{array}{l}\text { Sugars } \\
27.220 \% \\
\end{array}$} & \multirow{2}{*}{\begin{tabular}{|r|}
\multicolumn{1}{c}{ Corn } \\
Sweeteners
\end{tabular}} & \multirow{2}{*}{\begin{tabular}{|r|}
$\begin{array}{c}\text { Other } \\
\text { Sweeteners }\end{array}$ \\
$\mathbf{0 . 0 0 3 9 \%}$ \\
\end{tabular}} & \multirow{2}{*}{$\begin{array}{r}\begin{array}{c}\text { Artificial } \\
\text { Sweeteners }\end{array} \\
\mathbf{0 . 0 0 0 1 2 \%} \\
\end{array}$} & \\
\hline & & & & & & & & \\
\hline & & & & & \multicolumn{4}{|c|}{ Sweeteners consumption quantity change (\%) } \\
\hline & & & & Sugars & $\begin{array}{c}\text { Corn } \\
\text { Sweeteners }\end{array}$ & $\begin{array}{c}\text { Other } \\
\text { Sweeteners }\end{array}$ & $\begin{array}{c}\text { Artificial } \\
\text { Sweeteners }\end{array}$ & $\begin{array}{c}\text { All } \\
\text { Sweeteners } \\
\text { (sugar } \\
\text { equivalent) }\end{array}$ \\
\hline Milk & 100.44 & 1.004 & -0.368 & -1.190 & -11.604 & 0.806 & 6.654 & -7.419 \\
\hline Cheese & 65.55 & 1.000 & -0.002 & -0.853 & -12.803 & 0.525 & 0.153 & -8.951 \\
\hline Ice cream / yogurt & 27.39 & 1.006 & -0.557 & -1.403 & -9.110 & 0.933 & 5.643 & -5.245 \\
\hline $\begin{array}{l}\text { Breakfast cereal / } \\
\text { Bakery }\end{array}$ & 149.78 & 1.006 & -0.231 & -7.838 & -5.962 & 0.891 & 4.641 & -6.684 \\
\hline Soft drink & 118.41 & 1.012 & -1.179 & -2.020 & -16.417 & 3.663 & 1.879 & -14.271 \\
\hline Juice & 42.96 & 1.003 & -0.104 & -1.014 & -14.011 & 2.680 & 0.664 & -10.721 \\
\hline Sweetener products & 87.56 & 1.030 & -1.487 & -11.072 & -8.356 & 4.205 & -1.275 & -10.102 \\
\hline $\begin{array}{l}\text { Processed fruits and } \\
\text { vegetables }\end{array}$ & 29.39 & 1.003 & -0.579 & -1.516 & -14.570 & 1.437 & -0.055 & -11.333 \\
\hline Condiments / Spices & 104.65 & 1.001 & -0.149 & -1.239 & -7.354 & -0.148 & 0.718 & -3.173 \\
\hline Sweeteners & \multicolumn{2}{|c|}{$\begin{array}{c}\text { Initial per capita } \\
\text { sweeteners } \\
\text { consumption (lbs) }\end{array}$} & \multicolumn{2}{|c|}{$\begin{array}{c}\text { Sweeteners } \\
\text { consumption quantity } \\
\text { change }(\%)\end{array}$} & \multicolumn{2}{|c|}{$\begin{array}{c}\text { Initial per capita } \\
\text { sweeteners consumption } \\
\text { (dollars) }\end{array}$} & \multicolumn{2}{|c|}{$\begin{array}{c}\text { Sweeteners consumption } \\
\text { value change }(\%)\end{array}$} \\
\hline $\begin{array}{l}\text { All Sweeteners } \\
\text { (sugar equivalent) }^{\mathrm{b}}\end{array}$ & \multicolumn{2}{|c|}{105.69} & \multicolumn{2}{|c|}{-10.000} & \multicolumn{2}{|c|}{22.66} & \multicolumn{2}{|c|}{19.891} \\
\hline Sugars & \multicolumn{2}{|c|}{61.90} & \multicolumn{2}{|c|}{-8.874} & \multicolumn{2}{|c|}{13.8} & \multicolumn{2}{|c|}{17.351} \\
\hline Corn Sweeteners & \multicolumn{2}{|c|}{54.81} & \multicolumn{2}{|c|}{-12.414} & \multicolumn{2}{|c|}{7.31} & \multicolumn{2}{|c|}{28.726} \\
\hline Other Sweeteners & \multicolumn{2}{|c|}{2.86} & \multicolumn{2}{|c|}{1.275} & \multicolumn{2}{|c|}{0.94} & \multicolumn{2}{|c|}{1.299} \\
\hline
\end{tabular}




\begin{tabular}{|c|c|c|c|}
\hline Artificial Sweeteners & -0.043 & 0.61 & -0.024 \\
\hline Real expenditure on & Initial per capita real expenditure (dollars) & \multicolumn{2}{|c|}{ Real expenditure change (\%) } \\
\hline & 726.13 & & \\
\hline Welfare & \multicolumn{3}{|c|}{ Market welfare change } \\
\hline EV (million dollars) & \multicolumn{3}{|c|}{-1668.119} \\
\hline Per capita EV (dollars) & \multicolumn{3}{|c|}{-5.952} \\
\hline EV/Income (\%) & \multicolumn{3}{|c|}{0.032} \\
\hline
\end{tabular}

Source: Elasticities for final products are from USDA/ERS, 2008a and Chouinard et al. 2010 (see Tables 6 and 7).

a. Initial prices are normalized to $\$ 1 /$ unit.

b. See Table 10, footnote b. 